\title{
En verder...
}

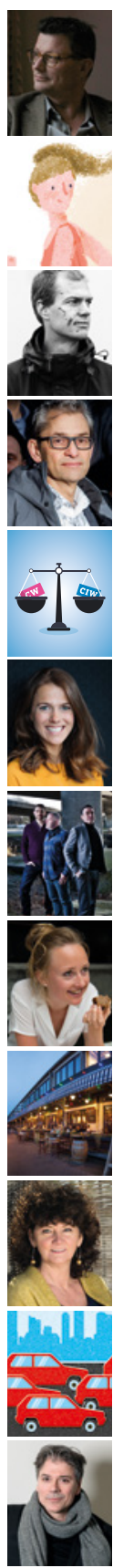

04 hoofdartikel

08 noelle aarts

12 ontwikkeling

16 pick my brain

18 toonaangevend

23 bartho boer

24 recensies

24 moet je lezen

26 kwartaaldicht

28 kennis

31 estafette

$38 \quad$ kleiner dan 10

$40 \quad$ jong

44 reportage

48 de snijplank

50 trends

53 innovatie in het vak

54 spotlight

58 reportage

62 medewerkers

63 de uitsmijter van de bruin

63 colofon

\section{LOGEION}

de nederlandse beroepsorganisatie voor communicatieprofessionals

\section{- LIDMAATSCHAP}

Het lidmaatschap van Logeion is inclusief een abonnement op C. Ook niet-leden kunnen zich op C abonneren. Voor meer informatie over lid worden van Logeion en opzeggen:

www.logeion.nl

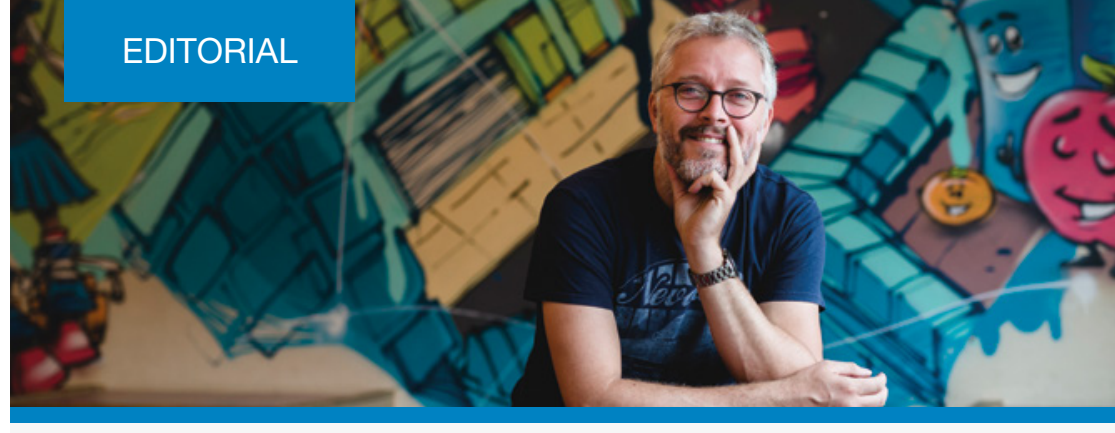

Fotograaf Marieke Odekerken

\section{De negende kunst}

Ik kwam er al toen ik een jaar of vijf was en ik kom er nu nog steeds. Yendor, de stripboekenwinkel die al meer dan veertig jaar in het centrum van Rotterdam zit. Ik kwam er al toen het nog ongepast was om strips te lezen, toen de gedachte nog was dat je ervan ging stotteren. En ik kom er nog nu de strip wellicht meer krediet heeft dan veertig jaar geleden, maar het nog bepaald niet gezien wordt als de negende kunst. In de ons omringende landen, vooral die ten zuiden van onze landsgrenzen, heeft de strip die status wel.

En terecht. Want een goed stripboek is meer dan een taalwereld waarin elke zin eindigt met een enthousiast uitroepteken, alsof iedereen de hele dag tegen elkaar loopt te brullen. De strip is alom vertegenwoordigd. Van prentenboekjes voor het zich ontwikkelende kind tot volwaardige romans en journalistieke verslagen van gruwelijke episodes uit de menselijke geschiedenis. En de strip is het propagandamiddel bij uitstek. Denk aan ons eigen land voor de oorlog, toen posters voor politieke partijen nog kunstwerkjes van meestertekenaars waren. Denk aan totalitaire regimes die de werkelijkheid geweld aandoen door een verstripte en vooral ten voordele van het eigen regime verbeterde versie van de werkelijkheid te presenteren. De strip is de werkelijkheid en de strip is de verbuiging van die werkelijkheid. Soms opzichtig, soms subtiel. Maar dát is in onze communicatiewereld niets vreemds meer.

In mijn ogen moeten er meer strips gelezen worden. Als ik bij mij thuis kijk, is het stripboek de toegangspoort tot literatuur en tot creativiteit. Mijn zoon doet niets liever dan in mijn enorme verzameling strips duiken. Daarna verslindt hij een boek zo dik dat het tillen ervan alleen al tot een tennisarm leidt. En als dat uit is, pakt hij zijn schetsboek, waarin hij inmiddels de prachtigste werelden op papier tovert met kroontjespennen, kalligrafeerkwastjes en brokken houtskool.

De tijd dat je van strips ging stotteren ligt achter ons. Nu is het tijd om er ook die negende kunst in te gaan zien.

\section{Sander Grip}

hoofdredacteur 
Communicatie bij verandering

\section{moet vaker schuren,} verontrusten, frustreren

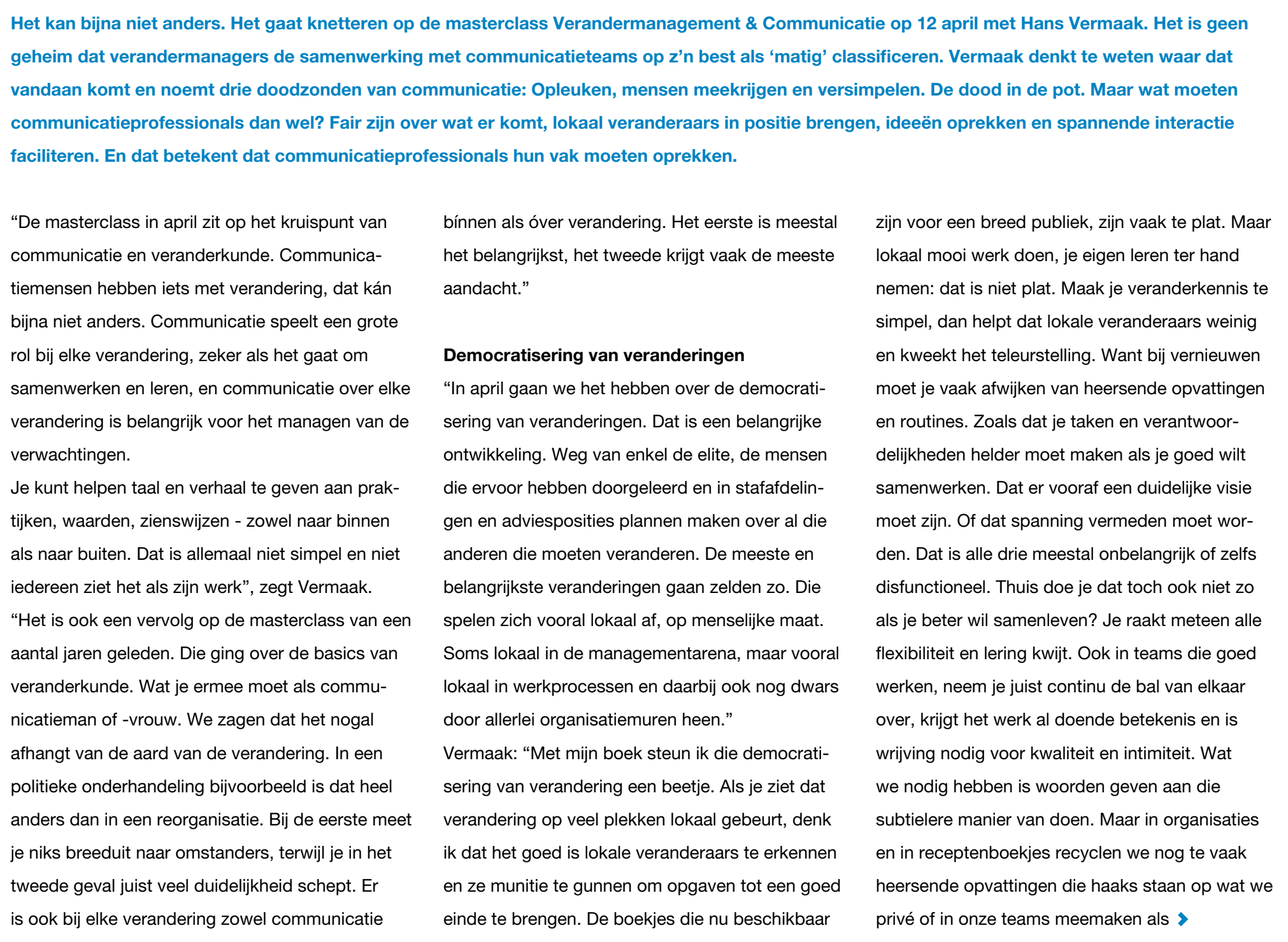




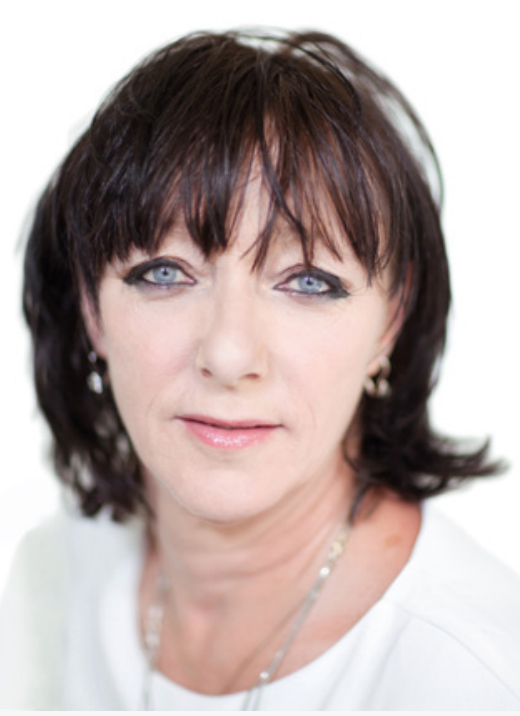

In de samenleving van vandaag raken we er langzaam maar zeker van doordrongen dat alles en iedereen met elkaar is verbonden. Wat vandaag gebeurt houdt verband met wat gisteren aan de orde was en wat morgen zal plaatsvinden. Wanneer het ijs smelt op de Noordpool zitten wij straks met natte voeten, of erger. Om grote uitdagingen zoals klimaatadaptatie, energietransitie, voedselproductie en migratie het hoofd te bieden, zijn we afhankelijk van elkaar. Ook - en misschien wel vooral - van degenen die heel anders tegen de situatie aankijken.

idee om afhankelijkheid als mot dat vinden we lastig. Afhankelijkheid kan dan wel de realiteit zijn, individuele vrijheid, autonomie en onafhankelijkheid zijn nog altijd belangrijke idealen in onze westerse samenlevirg.

\section{Beweging en afhankelijkheid}

Inspirerend is in dit verband het boek 'Ubunt

Stroom van het bestaan als levensfilosofie' van Zuid-Afrikaanse filosoof Mogobe Ramose. Ubunt is een eeuwenoude Atrikaanse filosofie die uitgaat van twee principes in onze samenleving: beweging en afhankelijkheid. Ubuntu ziet het leven ats

\section{Een kwestie van vertrouwen}

en onophoudelijke ontwikkeling, als een stroom. Daaruit vloeit voort dat alles en iedereen met akaar is verbonden en dus dat alles en iedereen van elkaar afhankelijk is.

Athankelijkheid vraagt om vertrouwen. Als baby leren we om te vertrouwen op de mensen die voor ons zorgen. We moeten well Als de eerste ervaringen goed zijn, dan blijven we in principe de wereld met vertrouwen tegemoet treden. Gaat het nie goed, dan krijgen mensen last van bindingsangs. Zo hangen de acceptatie van afhankelijkheid en vertrouwen met elkaar samen.

Nu brengt vertrouwen altijd een zeker risico met ich mee; ergens op vertrouwen betekent immers dat je het niet zeker weet. Het goede nieuws is dat de meeste mensen te vertrouwen zinn, het goede doen, simpelweg omdat ze daar belang ebben. We willen heel graag dat andere mense indruk hebben dat we goed bezig zijn. We

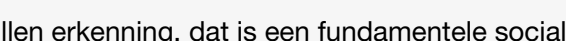
behoefte. Om die reden stelt de socioloog Olav velthuis dat we ons vermogen om ons kwetsbaar op te stellen en een ander te vertrouwen maar beter kunnen cultiveren.

\section{‘Ergens op}

vertrouwen betekent dat je het niet zeker weet

Machtsverhouding

controle varen en vertrouw op de halilitit de medewerkers. Zo behouden we ook in deze dynais bij afthankelljkheid ook haast altijd een verschil mische tijd organisaties die een prettig werkkliin macht. Denk aan de verhouding tussen de werkgever en de werknemer, de leraar en de leerling, de arts en de patiënt, de ambtenaar en de vluchteling, de klant en het bedriif.

Hier krijgt communicatie betekenis. Communicatie is het instrument om machtsverhoudingen op de kaart te zetten, wederzijds vertrouwen te creeren ve bjbehorde antankelijkheden op prettige wijze vorm te geven, met het oog op het bereiken van bepaalde ambities. Samen staan we sterk. Termen gedrag en collectieve emoties stellen de gezamenlijkheid voorop in plaats van het individu. Het is heel belangrijk om dergelijke termen te gebruiken. We weten immers dat mensen de werkelijkheid maken terwili ze erover praten: zo brengen we vertrouwen en productieve afhankelijkheden dichterbj

Voor communicatieprofessionals ligt hier opnieuw een goede reden om het top-down verspreiden van boodschappen aan te vullen met het creëren van verbindingen, tussen mensen van verschillende niveaus, tussen afdelingen binnen een organisatie, tussen de organisatie en de omgeving van wie zij zich afhankelijk weet.

Dit sluit weer aan bij het toenemende belang van de social media, resulterend in wat de socioloog Manuel Castells massazelfcommunicatie noemt: iedereen kan het initiatief nemen om informatie te verspreiden via social media. Daarom is de taak van communicatieprofessionals niet meer om voortdurend alles zelf te communiceren en de communicatie te controleren, maar om ervoor te zorgen dat alle medewerkers leren communiceren om zo de communicatiekracht van alle medewermedewerkers. Zo behouden we ook in deze dynamaat en daarmee een leefbare en menswaardige samenleving garanderen. als reciprociteit, cocreatie, verbinding, besmettelijk

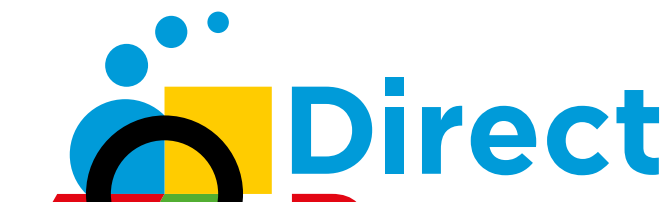 Research \\ maakt het makkelijk}

\section{Hoe speelt $u$ in \\ op het veranderend gedrag van uw doelgroep?}

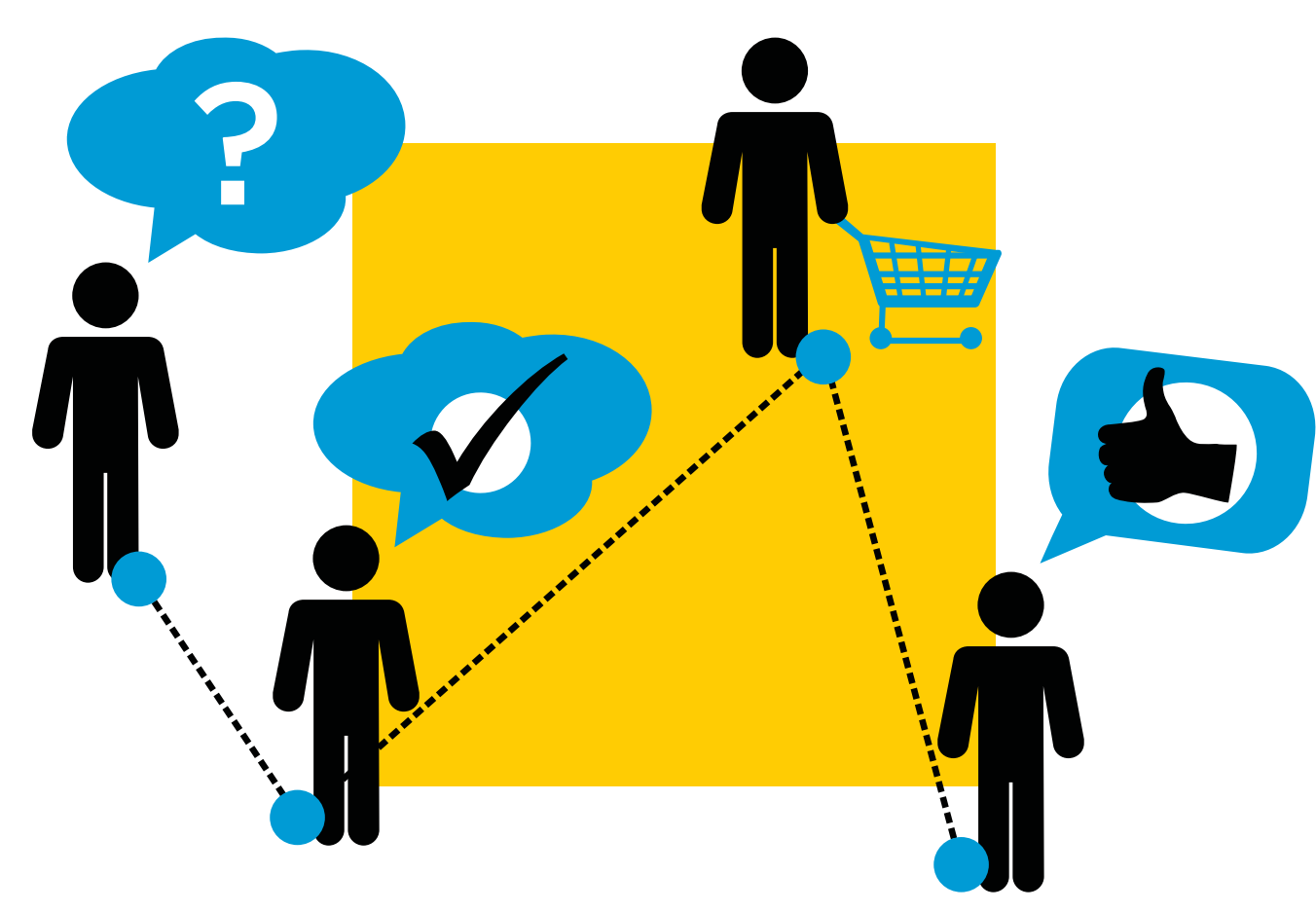

In de snel veranderende markt is het steeds lastiger om de wensen en behoeften van uw doelgroep inzichtelijk te krijgen. DirectResearch helpt u hierbij door middel van Customer Journey Optimalisatieonderzoek

Maak gebruik van de speciale kortingsactie! Kijk op www.directresearch.nl/actie of neem contact op via〔020-7707579 of@info@directresearch.nl 

LEGE TERMEN, VOLLE KAART niet zoveel deliverables (resultaten) zal opleveren

Elke keer als de Nederlandse captains of industry een meeting of the minds hebben, lijken er weer méér Engelse termen de Nederlandse taal in te sijpelen. Een bloody shame. En het kan anders! Hoe? Cut Hurthe crap, go with the flow. Enkele tips \& tricks om je moerstaal te spreken. reminder

creative copywriter
1 Bullshitbingo is en blijt een popular spel in menig meeting room (vergaderkamer). Al voordat de kick-off (aftrap) is gegeven van een stand-up (sta-sessie), duiken de eerste onnodige Engelse woorden op. Een kwartier voor aanvang: de reminder (herinnering). ETA's (verwachte aankomsttijden) worden doorgeseind via verschillende devices (apparaten). De teleurstellende turn-out (opkomst) doet vermoeden dat issues (problemen) waren met de invite (witnodging). Of zou he ment (betrokkenheid) zijn? Whatever. Al gauw blijkt dat deze all hands (sessie met z'n allen) lang als gehoopt. Maar de bingokaart is vol. Hell yeah!

Geregeld valt het woord 'churn' in
gesprekken op kantoor. Het lijkt wel of daarmee een hippe of juist verdekte term is gedaarmee een hippe of juist verdekte term is ge-
vonden voor 'weglopende klanten' of 'draide vonden voor 'weglopende klanten' of 'draaideurklanten'. Waarom het beestie niet bij zijn naam noemen? Bovendien is het een typisch geval van jargon: bijna elke nieuwe medewerker zal zijn eerste bezoek aan Google gebruiken om de vertaling van churn op te zoeken.

DENSELIJKE HULPMIDDELEN Je eigen taal terugtoveren in je
business (bedrijf), begint bij hoe je mensen noemt. Voordat men sprak van corporate staff of human resources (om maar te zwilgen over hum capaligen over human capitall, bestonden er termen als Klinkt eigenlijk persoonlijker en menselijker dan de Engelse varianten. En ja, 'planning' is in feite ook Engels, klopt.

UITDAGINGEN
REGELAAR OF LEIDER?
De wildgroei aan Engelse job titles
(functienamen) is natuurlijk begonnen bij het woord 'manager'. In sommige functios betekent deze term in feite 'regelaar', maar vaak doelt men met manager toch op de hoogst geplaatste persoon binnen een afdeling. Baas of leider klinkt wellicht wat ouderwets en zwaar, $m$ laten we eerlijk zijn: die termen zijn toch duidelijker dan het o-zo-gangbare 'leidinggevende'. Gek genoeg gebruiken we dat laatste woord trouwe wel in de sprekt "Dat met ik overleggen $m$ mijn leidinggevende "maar die term vind je bijn nooit terug in een organogram (ook wel: bedrifsplaat) of op een business card (zeg maar visitekaartje).

\section{‘Coolblue}

heeft een eindbaas,

hen als 'praatiesmakers'. Overigens verschinnen zii in geval van quotes wel gewoon in de krant als woordvoerder, hoor. Dus de buitenwereld doet et echt mee met dit omdenken, maar dat maak niet uit: de 'tone of voice' (toonzetting) is gezet. Waarschijnlijk zijn deze komische 'nicknames' (b amen) voor veel bedrijven veel te creatief. Maar laat het een incentive (aansporing) zijn om jezelf challengen (uit te dagen), okay?

LAAGHANGEND FRUIT ming van hypes en trends die overwaaien uit Engelstalige landen. Social media. He scheelt slechts één letter en je hebt een Nederlandse term. Klaar. En is het echt zo'n probleem om een infographic een infografiek te noemen? Een 'How to'-filmpje is toch gewoon een 'gebruksaanwizing' of een 'gebruiksviden'? 'Mak brilsaam io of is een bjzondar goval. Dal is zon video of een fotoreeks die een inkijk geeft in het maakproces, dat je normaal niet te zien krijgt. Niet alleen kun je zoiets mooier aanduiden als een "blik achter do schermen', maar steeds meer mensen schrijven tegenwoordig 'making off', waarbij ze dus een 'f' teveel schriven en darme laten doorschemeren tever dat Engels niet hun sterkste punt is. Nog een ex

\section{- Geen praatues, MAa} Gelukkig komen de oer-Hollandse Itels langzaam maar zeker weer in opmars. Sabel Communicatie zocht een 'schrijver op gympen' in plaats van creative copywriter of content mager. Coolblue noemt zijn directeur 'eindbaas', de salarisadministrateur 'verloningskoning' en de klantenservice-trainer 'mondhoekmonitor'. Waar veel bedrijiven hun woordvoerders heel deftig 'press officers' noemen, bestempelt Coolblue

T. KEIHARD INGEBURGERD Hardnekkiger zijn begrippen als 'online' en 'coach'. Zulke woorden zijn inmiddels keihard ingeburgerd. Vaak kun je 'online' vervangen met '(op) internet', maar dat errtraagt vaak de boodschap, minimaal met één ettergreep. Bovendien is het meest gangbare synoniem voor 'coach' het evenzo Engelstalige woord 'trainer'. Dus misschien moeten we op sommige momenten inderdaad onze schouders maar ophalen. Shake it off.

\section{'IK HEB EeN BEETJE JeUK AAN} MIJN USP

Nou, nog eentije dan. De corporate story begint met een mission statement, waarn je via storytelling en storydoing tot proof points of best practices komt van jouw unique selling points. Rewind selecter! Het bedrifssurbal begint

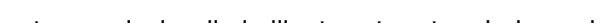
on die joum unieke kwalititen bewijzen. Can you dig it?

De meeste artikelen en columns over kantoortaal staan tjokvol vreselijke termen waar we samen hard om kunnen lachen. Maar oplossingen blijven vaak uit. Hopelijk kun je met deze handreiking op weg naar een gezonde brainwave. Duik erop, asap, met je hands-on mentaliteit. Geef er maar lekker follow-up aan en voorkom epic fails. Pak de lead, schud je stakeholders en consultants wakker. Geef je performance of a lifetime. Maak bullshitbingo een no-go area. En geniet van je 


\section{Frankwatching en Logeion slaan de}

\section{handen ineen}

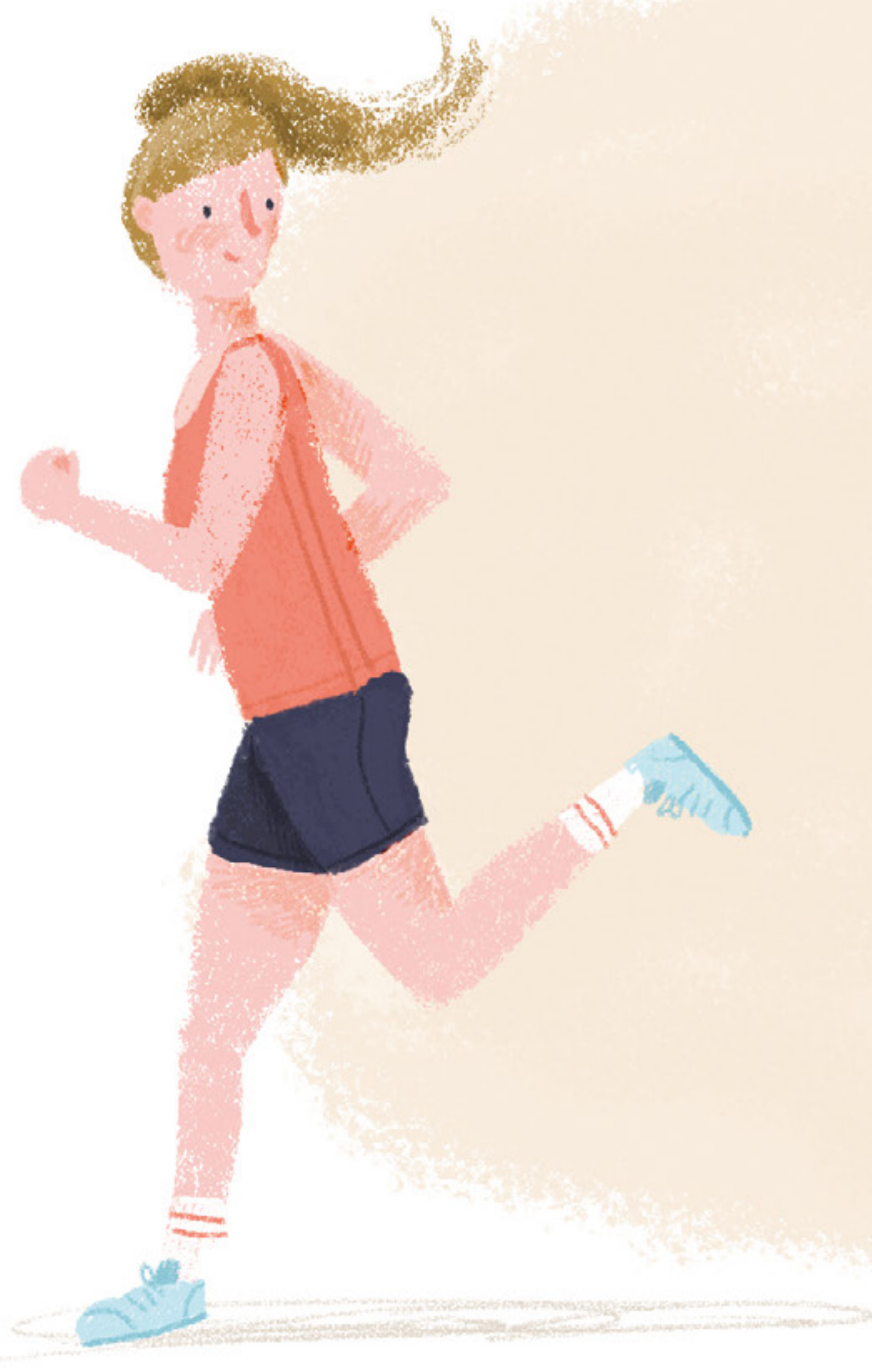

\section{NIEUWE VOLGERS}

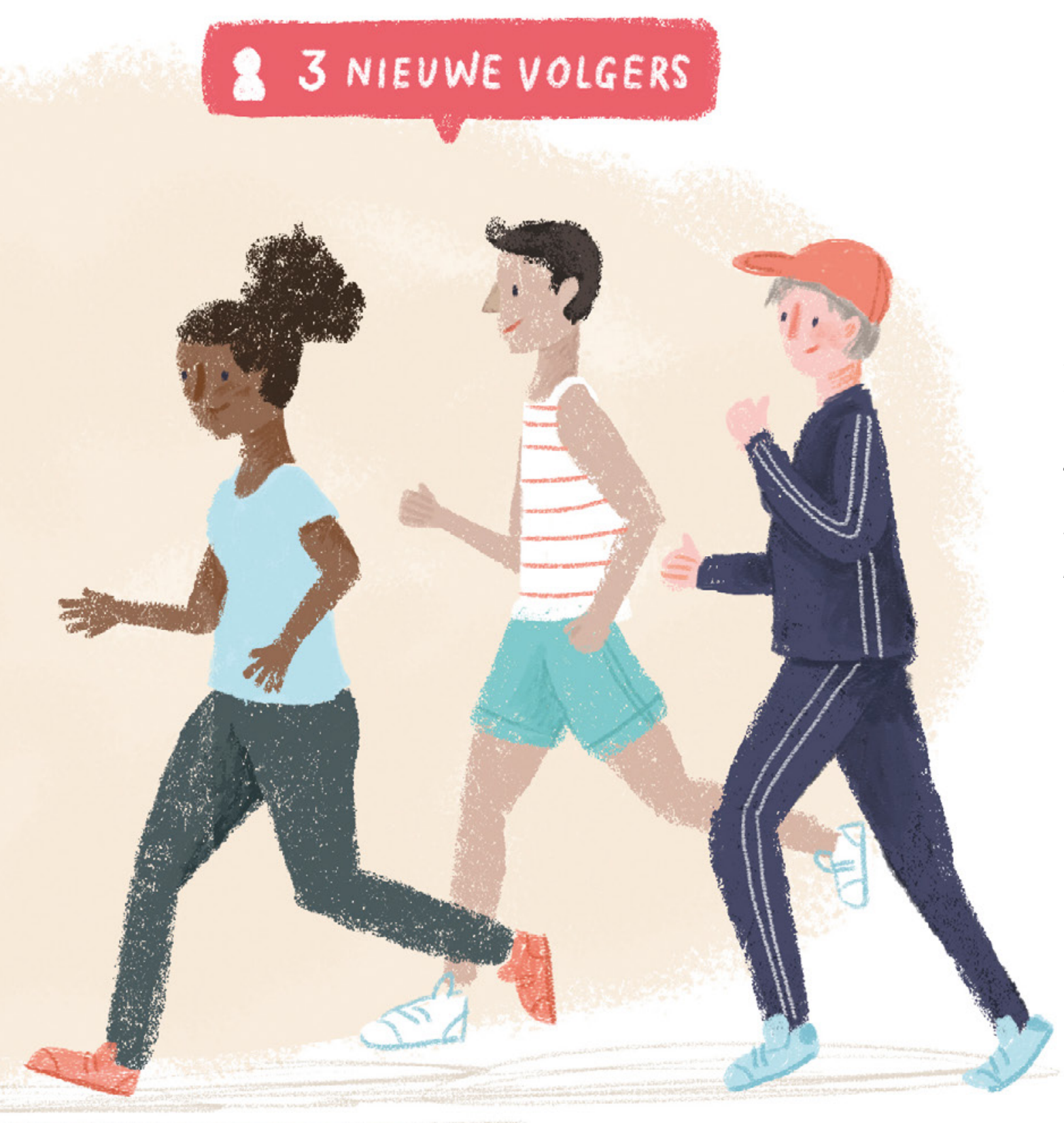

rankwatching en Logeion maakten afgelopen november bekend de samenwerking te intensivere. vamenwerking te intensiveren. directeur van Logeion.

\section{Logeion niet digitaal genoeg?}

"Dat is wel heel kort door de bocht. Als je kijkt naar onze programmering de afgelopen maanen dan heeft digitale communicatie zeker een Mar de ontwikkelingen gaan

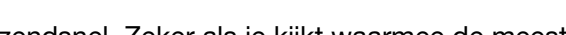
mmunicatiecolleg's tegenwoordig dageliks bezig zijn. Het is alles of niets. Het is niet meer o of, maar en/en. Digitale communicatie is een wezenijk onderdeel van deze werkzaamheden. Ook werneer je werkzaam bent in 'klassieke' commuiatiefuncties als interne communicatie, public a (1) anagers, sociale-media-analisten. En als je met e blik naar Logeion en onze programmering kijk,

dan zijn we nog niet waar we moeten zijn."

\section{Is het ook e} . 'nieuwe generatie communicatieprofessionals' zich aansluit bij Logeion, omdat men ziet dat wij voorzien in een behoefte op het gebied van digitale communicatie. Maar het belangrijkste is natuurlijk dat je je als beroepsorganisatie voortdurend moet blijven ontwikkelen. Op alle terreinen van het vak maar zeker op he gebied van online communicatie. En omdat je niet alle kennis en vaardigheden in eigen huls hebt, ga je op zoek naar een partner met wie dat goed zou kunnen doen. En dan kom je al snel bij de collega's van Frankwatching uit.'

Voor Logeion-leden die dat niet weten, wat is Frankwatching?

"Frankwatching.com is een Nederlands weblog. Het publiceert sinds 2004 nieuws en opinie ov media, marketing en digitale trends. Frankwatching is binnen digitale marketing en communicatie uitgegroeid tot het grootste platform van Nederland. De website heeft een actieve en beseche Theer man 450.000 ver Frankwatching traint daarnaas jaarinks duizenden professionals via open inschriving, in company en maatwerk. Zij doen dif in de vorm van korte opleidingen, (online) trainingen en live webinars in de vakgebieden content \& communicatie, digitale commercie, marketing SEO \& analytics en sociale media."

Hoe ga

"Frankwatching en Logeion zijn geen onbekenden voor elkaar. Onze samenwerking is niet nieuw maar krijgt een verdere verdieping. Het meest in het oog springende onderdeel van onze samenwerking is dat we onder de no on in Digital' dit ja on ser zoals ze bj Frankwatching heten, behandelen we onderwerpen als sociale content, analytics en online overreding. Het speelt direct in op de wens van onze leden en de ontwikkelingen in het communicatievak. Door met Frankwatching samen te werken kunnen we nu ook een programma aanbieden op het gebied van digitale communicatie. En dit sluit ook weer heel mooi aan bij onze Logeion-trends 2018/2019." । 


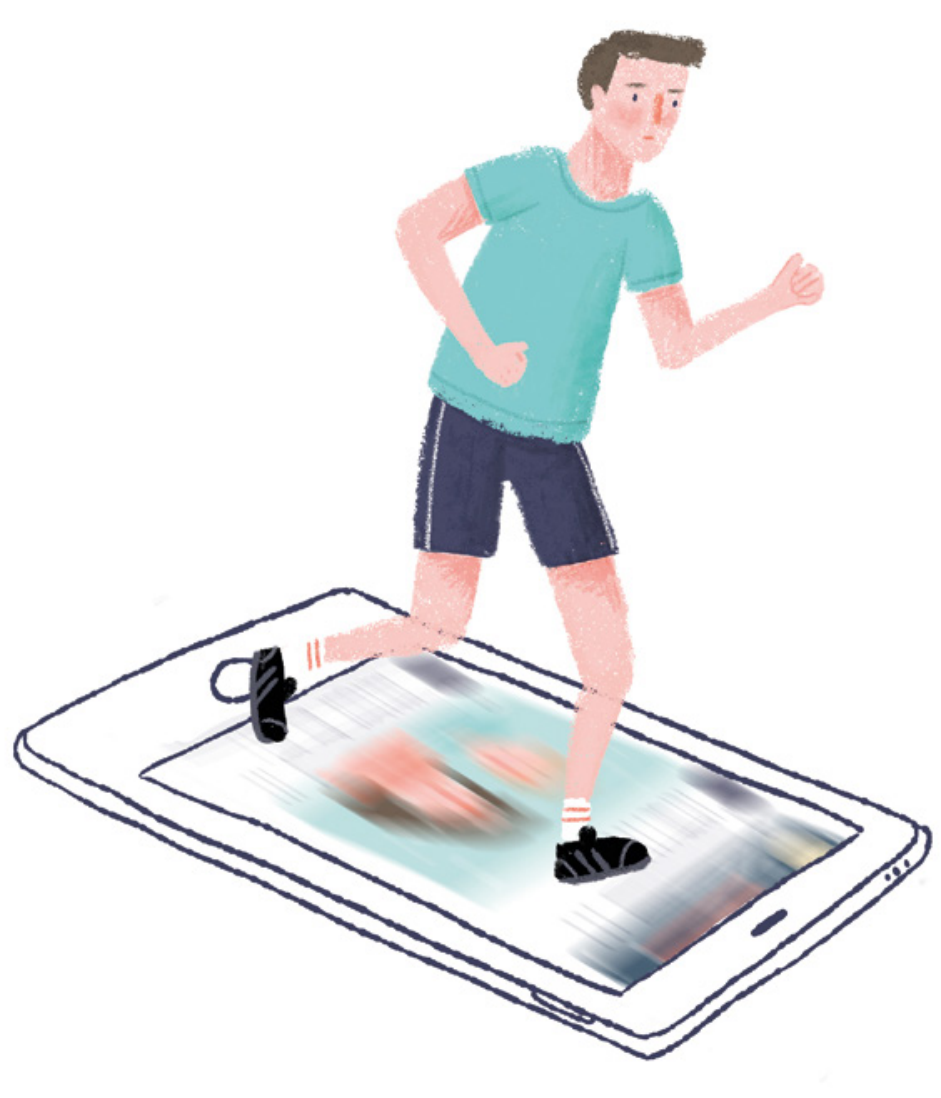

\section{Nieuwe impuls voor het}

\section{vak}

Maaike Vissink is chief commercial officer van Frankwatching. Zij denkt dat de samenwerking een nieuwe impuls kan geven aan het

communicatievak: "Frankwatching leidt jaarlijks duizenden professionals op en is drie jaar op rij uitgeroepen tot topopleider in marketing \& communicatie. Door ons grote netwerk en brede kijk op online zijn we in staat voor elk onderwerp de juiste experts te vinden. Wij kijken ernaar u onze kennis over digitale tren rends en thema's in delen.

Via 'What's going on in Digital' bundele beide partijen de krachten op het vlak van het ontwikkelen en aanbieden van kennissessies en hieraan gerelateerde trainingen over digitale trends \& topics. De samenwerking draagt bij aan de professionalisering van het snel veranderend communicatievak. Maar de samenwerking gaat verder, naast de vier bijeenkomsten kijken we samen hoe we elkaar verder kunnen versterken en elkaars leden en 'volgers' nog beter van dienst kunnen zijn. Daarbij valt te denken aan

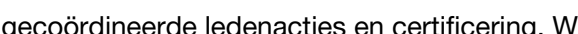
hebben ellar zoveer to beden vor min z d vier bijeenkomsten in het kader van 'What's going on in digital' daar een heel mooi voorbeeld van."

Wat bieden de cursusleiders van Frankwatching in de intensievere samenwerking?

\begin{tabular}{|c|c|c|}
\hline Op 22 maart 2018 vindt de kick-off van 'What's & Bedrijven en organisaties vinden het vaak moeilijk & maliseerd wordt tot een bericht dat maximale \\
\hline ing in & niet over zichzelf te praten. Ze nemen niet de tijd & aandacht krijgt." \\
\hline $\begin{array}{l}\text { UIM (Jaarbeurs) Utrecht. Instagram en Snap- } \\
\text { chat-expert Kirsten Jassies en sociale-media- }\end{array}$ & $\begin{array}{l}\text { om erbij stil te staan wat hun doelgroepen eigenlijk } \\
\text { bezighoudt. Key Performance /ndicators (KPI's) }\end{array}$ & Kim Swagemakers \\
\hline strateeg Kim Swagemakers gaan in op de & gaan over bereik, views, engagement en clicks. & Voorbij oudere content \\
\hline thema's sociale content en visuele verhalen & Absoluut mee eens, maar zonder die eerste atten- & "II mijn sessie ga ik het onderwerp 'stories' \\
\hline 8 bekendgemaakt. De data voor de & Een goed voorbeeld is de laatste grote verandering & ele, tijdelijke en beeldvullende verhalen die je \\
\hline andere bijeenkomsten zijn inmiddels ook & van Facebook, die volledig draait om waardevolle & zelf kunt bewerken. Je vindt ze op Instagram, \\
\hline bekend: 7 juni, 13 september en 20 november. & $\begin{array}{l}\text { inhoud. Binnenkort zien niet je fans je berichten, } \\
\text { maar alleen je fans met de instelling 'see first'. Dat }\end{array}$ & $\begin{array}{l}\text { Snapchat, Facebook en WhatsApp en ze zijn } \\
\text { ook al gesignaleerd op websites als Mashable }\end{array}$ \\
\hline Aandacht trekken & vraagt om een nieuwe content-strategie, met als & en NRC. Bii jongeren zijn stories op sociale \\
\hline "We worden dagelijh & belangrijkste vraag: hoe kun je ervoor zorgen dat je & media zelfs zo populair dat ze bijna niet meer \\
\hline content c $\mathrm{C}$ & doelgroep stopt met scrollen? & naar oudere content kijken: een voorbeeld \\
\hline als een dolle door onze nieuwsfeed, totdat we & In mijn sessie op 22 maart ga ik dieper in op de & hiervan is de feed van Instagram. De interactie \\
\hline iets zien wat de aandacht trekt. En dat is voor & $\begin{array}{l}\text { "social customer journey", onlangs nog opgeno- } \\
\text { men in de top tien communicatiejeukwoorden. }\end{array}$ & $\begin{array}{l}\text { met je doelgroep door het maken van de juiste } \\
\text { stories schiet dan direct omhoog. De hoosste }\end{array}$ \\
\hline communicatieprofessional is $\mathrm{d}$ & Zodat de deelnemers aan de sessie precies weten & tijd om zelf met deze content van de toekomst \\
\hline stopt mijn doelgroep me & welk bericht op welk moment bij welke doelgroep & aan de slag te gaan en dat gaan we op 22 \\
\hline begeerde aanda & en via welk kanaal die felbegeerde aandacht reali- & maart doen." \\
\hline nen leestekens, foto's en video's die over het & seert. Na deze sessie hebben de deelnemers een & Kirsten Jassies \\
\hline
\end{tabular}

Kijken de leden van Logeion uit naar de intensievere samenwerking?

Logeion en Frankwatching slaan de handen nog nadrukkelijker ineen. Wat vinden de leden van Logeion daarvan? We vroegen het twee van hen.

Als we online niet oppakken, is het (bijna) over

"De samenwerking is een goed initiatief. Als het vakgebied communicatie online niet echt oppakt, is het (bijna) over. Dan is ICT leidend en HR pakt het engagementstuk wel op. Communicatie is dan nog wat traditionele pr en verder niks meer. Wil je relevant blijven as communicatieprofessional dan moet je je online vardigheden versterken. Ook de opleidingen moeten een inhaalslag maken. Via visitaties en examencommissies zie ik heel veel eindwerken. SEA kom ik (bijna) nooit tegen, ook al is de doelgroep heel goed te targetten. Waarom niet? Er is nooit aandacht aan besteed." Wil Michels, directeur Michels Communicatie docent Fontys Hogeschool en SRM

"As content manager ben ik continue bezig met de vraag: wat wil de doelgroep weten? Bij HVR
Group monitoren we daarom bijvoorbeeld voor onze klanten wat er speelt. Zo kunnen we de juiste onderwerpen vinden en analyseren wat er na het plaatsen van een bericht gebeur (zowel op social als van een bericht op een website). Naast het juiste onderwerp, ben ik ook altijd op zoek naar verschillende vormen van het plaatsen van content. lk kijk er dus erg naar uit om weer nieuwe tips te ontvangen!" Hanna van Woerden, content manager HVR Group 


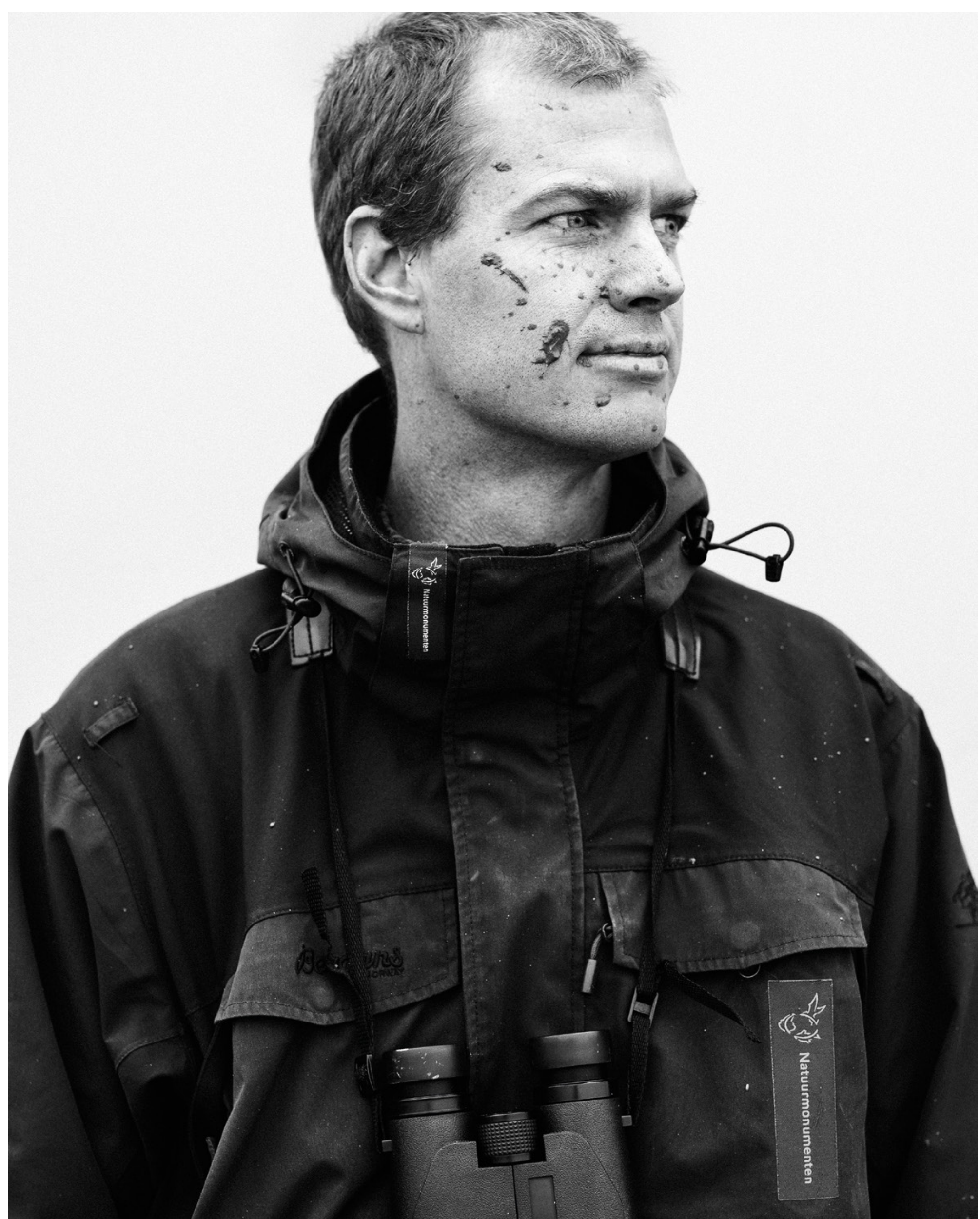

Juriaan van Leeuwen, boswachter

We verzinnen niks, maken het niet anders of groter. De werkelijkheid is goed genoeg

\section{Als een otter je communicatie-} strategie bepaalt

'Van buiten naar binnen denken.' Bijna iedere communicatieadviseur heeft de slogan wel eens gehoord of zelf gebruikt. In boswachter Juriaan van Leeuwens praktijk komt die zin niet voor. Hij denkt van buiten naar buiten.

"Het is besmettelijk", zegt Juriaan van Leeuwen, boswachter bij Natuurmonumenten in onder meer het gebied Nieuwkoopse Plassen. “Toen ik hier acht jaar geleden begon was ik wel graag buiten, maar dat ik veel van natuur wist, nou nee. Nu ken ik alle vogels bij man" Zi" a drachtogebied is com beren

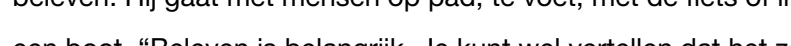

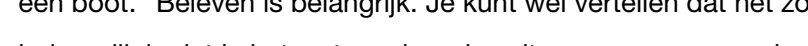
belangrijk is dat je het waler schoonnoudt, maar mensen voelen het pas als ze zien dat de snoek, de otter en de lepelaar weer terug zijn."

De otter is echt een icoon geworden voor de Nieuwkoopse Plassen, de gemeente heeft het zelfs op de plaatsnaamborden staan. Het dier was in 1976 al uitgestorven in de Randstad en hij is pas een paar jaar weer terug. Van Leeuwen: "De otter hij is pas een paar jaar weer terug. Van Leeuwen: "De otter spreekt tot de verbeelding, maar het probleem is dat je hem
niet ziet. Het is een nachtdier en hij is erg schuw. We hebben hier wel eens cameraploegen gehad die ons vroegen wanneer ze de otter konden filmen. Nou, niet dus." Van Leeuwen en zijn collega's zoeken continu naar manieren om de otter toch bij het publiek te brengen. "Dankzij wildcamer's kunnen we ze's En soms vinden we dode otters. Bovendien leggen ze hun uitwerpselen op markante plekken neer. Daarvan nemen we DNA monsters. Zo weten we dat er minimaal 16 individuen in dit gebied moeten zijn geweest."

Volgens van Leeuwen is de otter ambassadeur voor allerle andere dieren on planten. "Als boswachter vind ik soms just "Al bosw we ving de is het alleen maar een dik, groen sprietje. Maar het is een heel kieskeurig plantje en als het in jouw gebied groeit is da een enorme opsteker. Maar zo'n sprietie spreekt niet tot de verbeelding, een otter wel."

De natuur kun ie niet dwingen, die is zoals ie is Volgens van Leeuwen moet je dat ook niet willen. "We verzinnen niks, maken het niet anders of groter. Het is hier een prachtig gebied, met slooties, plassen en veel stille plekjes. Kinderen komen me schepnetjes en verrekijkers en vinden dat net zo leuk als de Efteling." Niet spinnen, niet oppompen en niet regisseren dus. De werkelijkheid is goed genoeg 
Jos van Winkel

nen

halve studie geneeskunde en

een hele studie wijsbegeerte

en literatuurwetenscha

terecht in overheidsland,

waar hij diverse strategisch

en leidinggevende rollen had

bij de gemeenten Amsterdam,

Zaanstad en Amersfoort

Momenteel werkt hij als

hoofd strategie, bestuur en

veiligheid bij laatstgenoemde

gemeente. Staat daar onder

meer aan de basis van het

programma Amersfoort

Smart City Hij wil het liefs

Smart City. Hij wil het liefs

ing

omdat hij dan nas an bio-

toop functioneert. Is ferven

aanhanger van de Brompton

vouwfiets, met zes versnellin-

gen, kan niet zoveel met saaie

mensen en is veel en vaak

op reis zonder echt vak

op remente

komen. Van Winkels tevens

Iid van de Logeion Adviesraad

Programmering en Trends,

participeerde in de Raad van

Advies van de Community of

Practice 'Veranderstad'en is

fan van Pakhuis De Zwijger.
Pleidooi voor de menselijke maat
Hili is aanjager van een eigenzinnig team waarin Een van die innovaties is Smart City Amersfoort. strategen en communicatieprofessionals direct met elkar kijk op de wertc Th ze zetten in hands-on projecten is Jos van 作 A inzichten, ideeën en projecten op tafel waarbij contact.

"In een stad die zich de laatste jaren zo sterk heeft ontwikkeld als Amersfoort, past een overheid die vernieuwend is; een gemeente die andere, moderne inzichten hanteert en . heel blij met minn team waar strategen en communicatieprofessionals elkaar dicht op de huid zitten. Dat is vijij bijzonder maar tegelijkertijd stad gaande ziin." Kort gezegd gaat het om het besturen van een mat behulp van informatietechnologie met als eel de levenskwaliteit te verhogen en de stad efficienter te organiseren en effectiever te besturen. . an ooit tevoren en zich met dezelfde informatiechnologie ook veel sneller kan organiseren. Van Winkel: “Het gaat daarbij om twee belangrijke (n) in hoog tempo leiden tot 0 n veranderende setting in

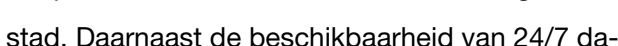
(a) ing mogelik Big data, atkomstig van bijvoorbeeld technische voelsprieten die in de stad zijn uitgezet. Denk aan sensoren op afvalcontainers die leiden tot efficiëntere ophaalroutes. Sensoren die de vrije fietsers, die bij regen eerder groen worden, sensoren die bij glacheid aangeven wanneer en waar we

grid over de stad dat ons dagelijiks voorziet van veel data ? 
en het eind daarvan is nog lang niet in zicht. Dat loept ook veel discussie op, denk aan camerato zicht. Big data kunnen enerzijds ons werk beter maken of input vormen voor onze strategische koers maar stellen anderzijds hoge eisen aan wa en hoe je communiceert. Miin stelling: er is veel meer maatschappelijk debat nodig ove helpt en wat te veel 'big brother' is."

De stad erbij betrekken

Een doordachte blend van strategie en communicatie vormt de basis voor de manier waarop in gemeente Amersfoort nu projecten worden aangevlogen. Een flinke dosis 'empowerment' brengt het

geheel op smaak.
Van Winkel: "Neem het project Meet je stad. brodpek voor onderzoek, duurzaamheid. Een mix van wetenschappers en kunstenaars. Dat geeft frisse ideeën en energie. Zo leren zij bewoners hun eigen kastjes te maken waarmee de luchtkwaliteit wordt gemeten. De data uit deze meetkasties worden online ontslo en dat leidt tot een fijnmazig net van metingen. Bewoners dragen actief bij aan de kwaliteit van hun eigen woonomgeving door zichtbaar te make hoe het er voor staat. Daarmee ontstaat eigenarschap bij bewoners en ondernemers. Die strate sche keuze leidt dan wel tot veel uitwisseling over wat zij zelf kunnen doen en wat wii als overheid kunnen faciliteren

Heel veel data

Smart City initiatieven zorgen voor ontzettend veel meer informatie over je eigen stad. En dat is nog niets vergeleken bij de datastromen die de techreuzen Google, Facebook, Amazon, Apple en Microsoft ons laten genereren. Verregaande digitalisering, terabytes ann data met uiteraard meer meerwaarde, maar die tegelly de vaag oproepen komen te staan.

"Een discussie over de impact van digitalisering is heel erg nodig," aldus van Winkel. "Niet vanwege verkeerde beeldvorming, maar om uit te vinden of en hoe je deze ontwikkelingen moet willen reguleren. Dan gaat het over autonomie, priva$c y$, athankelijkheid, toegankelijkheid enzovoort Daarnaar gaan we samen met twee universiteiten lokale ondernemers de komende jaren gericht onderzoek doen. De technologiegolf brengt enorme kansen, maar het mag ons niet overkomen dat je wakker wordt in niemand had gewild."

Maatschappelijk debat

'Zo'n maatschappelijk debat brengt ons middeni et communicatievak. We gebruiken inmiddels een methode van design thinking om dat deba vorm te geven en specifieke issues zoals parkeren in de binnenstad, aan te vliegen. We halen eerst veel inzichten en meningen op om de starturaag te herformuleren. Dan weer divergeren, oplossingen testen, tot conclusies komen. In kleine stapjes. Geen grote masterplennen die nogal eens de neiging hebben om vast te lopen, maar prototypes die via 'trial en error' steeds beter worden. Dat voorkomt grootschalig mislukken. Een beetie naar Fins model Dar werd de discussie over het basisinkomen uitgetild boven vastgeklor

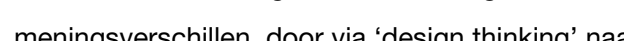
een gedragen werkmodel te komen. Met eigenaarschap van alle betrokkenen

Ook hier gaan strategie en communicatie gelijk op. Je betrekt je inwoners bij het ontwerpen van oplossingen. Dat is een hel feffecieve strategische kerze on gek genog ze IK tegellyelld d sche kazze an gek genog ze kk we voor het con hat met mwoners steeds minder gebruik maken van de traditionele mediamogelijkheden. Online mixt met low tech, ik bedoel de straat en het lichaam, dus elkaar fysiek weer ontmoeten, aanwezig zijn, de dialoog aangaan. Het menselijk gezicht staat centraal in het contact tussen bestuurders, inwoners en ondernemers. Bereme Beter int mentminder belag kis gew informatiebehoefte? Wat houdt mensen bezig? Daarna ontstaat pas tweezidigheid, en kun je bewust kiezen voor de vorm die daarbij past. Als communicatieprofessional geef je vorm en inhoud aan alle communicatiekanalen, online

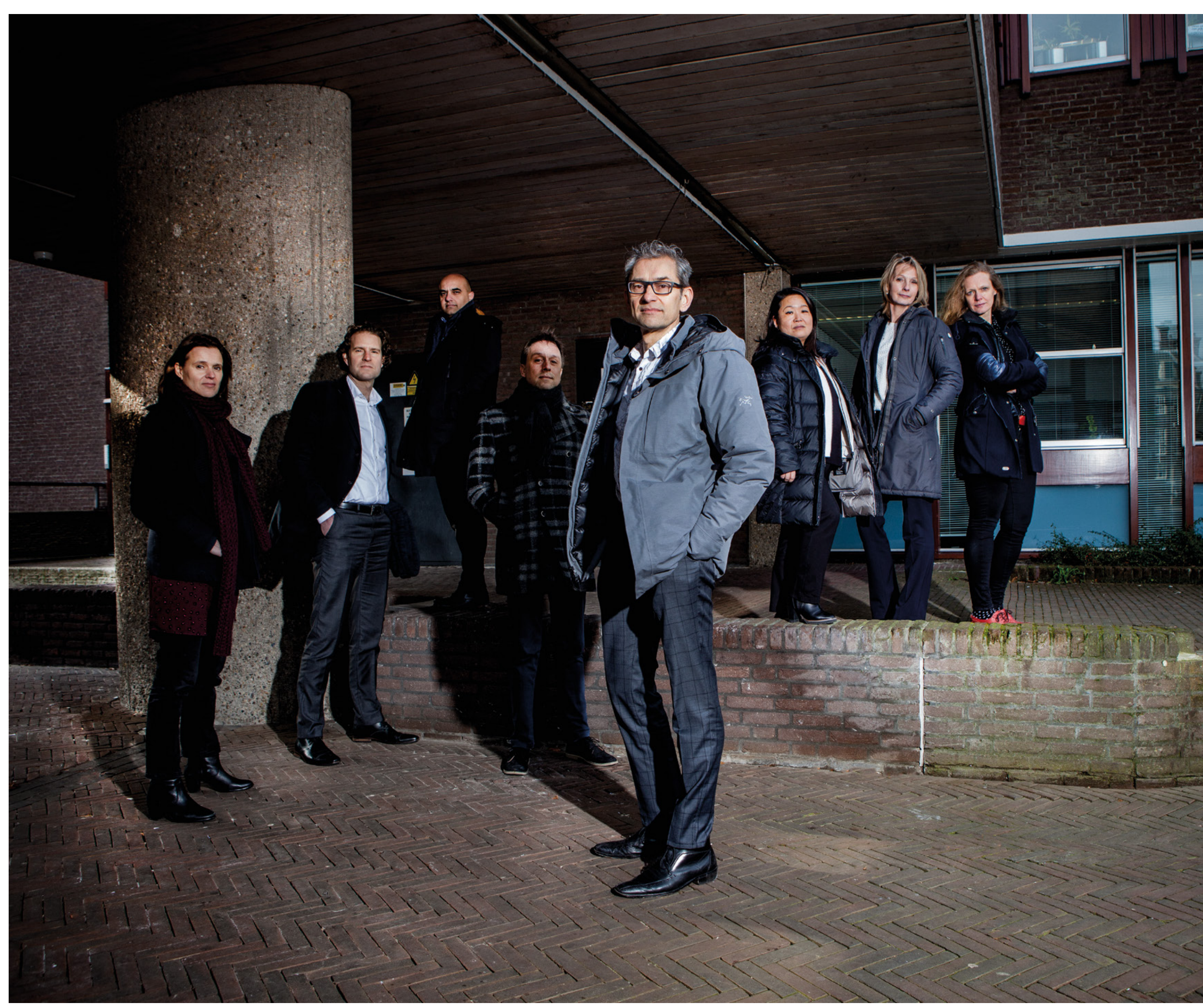


'Het draait te

vaak om het

profileren van

meningsverschillen

in plaats van

het zoeken naar

gezamenlijke

publieke

meerwaarde' en offline, high tech en low tech en altijd in samenhang met elkaar

\section{En de politiek?}

Van oudsher is een gemeente wellicht wat minder toegankelijk maar als we écht willen communtceren, stellen we vaker procesuragen en landen burgerinitiatieven makkelijer binnen de muren van het stadhuis. Dit inzicht heeft geleid tot nieuwe initiatieven. Een daarvan is Starten voor de start. Dat betekent dat we, voordat we ergens starkkaders aan meegeven, met inwoners, ondernemers in andere belanghebbenden in gesprek gaan.

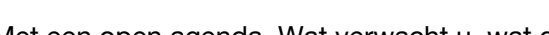
uet een open agonda. Wat vorwacht u, wat den dat het probleem is, wie zou welke rol moet nemen om tot oplossingen te komen? Voor de politiek, de gemeenteraad, betekent deze houding ook een aanpassing. Eigenlijk zijn de vormen waarin het politieke spel wordt gespeeld iet meer van deze tijd. Het draait te vaak om he priter van meningsverschilen in phats van profleren van meringsurs zoeken naar gez minke publeke meerwaar De Amersfoortse gemeenteraad is best stoer hoor, en experimenteert met andere vormen van besluitvorming. Raadsleden, ambtenaren en actieve Amersfoorters die in zogenaamde gemengd groepen gezamenlijk een probleem verkennen. Broedplaatsen. Cursussen 'werken met netwerken' en allerhande pilots en experimenten. Daa is ken' on allin. Cus her alen wing hoog op de agenda staat. Dat is nu meer dan ooit relevant omdat de grote opgaven war we voor staan, zoals energietransitie en Smar City ontwikkelingen niet mogelijk zijn met een gemarginaliseerd bestuur dat niet middenin $d e$ samenleving staat."

\section{Stad meteen hart}

Het is een mooie pay-off voor de stad maar het is waar: Amersfoort is een stad waarin vee onderlinge betrokkenheid bestaat en ambitie is om bestuurlijke vernieuwing te realiseren. Een bestuur dat dit echt wil, een actieve en betrokken
Auteur Bartho Boer hoofd communicatie Nederlandse Spoorwege Fotograaf Maaike Poelen

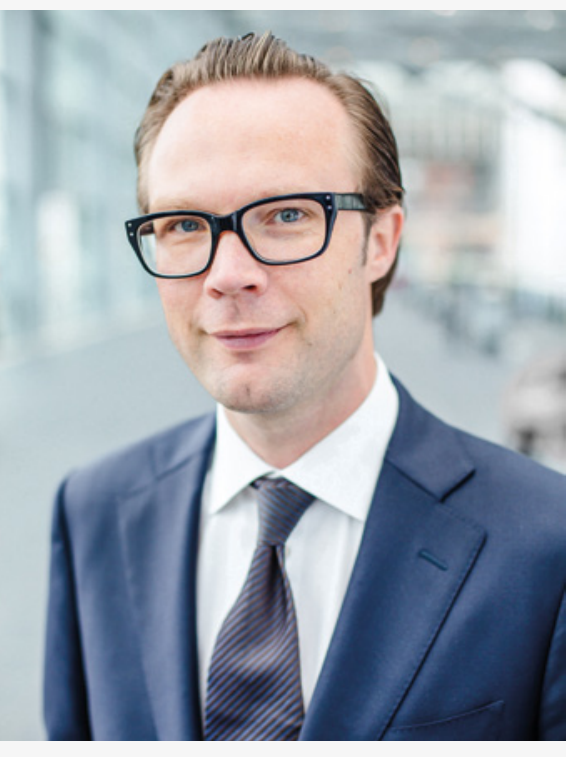

\section{Verantwoord} nemerschap en oog voor vernieuwing. Daardoor is er een hoge acceptatiegraad voor innovaties. Dus veel ruimte voor initiatief maar tegelijkertijd ben $\mathrm{ik}$ geen pleitbezorger van een terugtredende overheid want het 'schild voor de zwakken' is ook een rol die de overheid heeft. Vernieuwing mag geen negatieve consequenties hebben voor de solidariteit en sociale samenhang in de stad. Communicatie in deze nieuwe wereld vraagt van de communicatieprofessionals veel zelfreflectie en een natuurlijke drang te willen verbinden en on dat goed te doen. Veel luisteren, nieuwsgierig zijn en voortdurend blijven nadenken, ondanks alle big data."

En ij?

"IK zie minn eigen rol hierin als iemand die op lange terminn kijkt naar wat de impact van technologie is op onze samenleving. Die wil duiden wat er aan

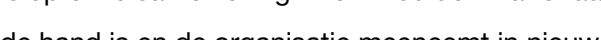
manieren on his maniren on hion es on garom is het zo mooi dat strategen en bestuursadviseurs communicatie met elkaar in een team functioneren. Ze kunnen elkaar enorm versterken en scherp houden. Ze ondersteunen burgemeester, wethouders en management als team, als klankbord met een sterk eigen oordeel. Daarmee ontstaat een eigenzinnige, onafhankelijke manier van opereren, terwiil ze tegelijk heel goed zijn in hun gevoel voor verhoudingen. Het schakelen is spannend en voor mij is het vooral een dagelijks plezier met zulke goede mensen te werken." •
De toenmalige huisfilosoof van de Gemeente Amsterdam leerde mij ooit dat integer handelen rover gaat dat je op een redelijke wijze alle belangen van alle betrokkenen hebt afgewogen voorda fe een besluit neemt. In sommige gevallen is het onmogelijk dat niemand schade ondervindt van wat jij doet. Zo is het leven nu eenmaal, zei hij, dat It vol dilemma's. Je kunt jezelf hooguit trainen o weloverwogen besluiten te nemen, zeker als het verstrekkende gevolgen heeft.

Hoe zit het met de ethiek in communicatie? Waarom staat vertrouwen zo onder druk? En wat kan communicatie daaraan bijdragen? Een antwoord op die vragen kun je zoeken met behulp van het boek Communicatie en Ethiek van Nico de Leeuw en Jan Merton of het witboek dat Monique Janssens schreef over Maatschappelijk Verantwoord Communiceren

en organisatie moet eerst betrouwbaar zijn en pas daarna kan met communicatie worden gewerkt aan het verkrijgen van vertrouwen, stelle De Leeuw en Merton. De communicatieprofessional is 'bij uitstek' degene die weet wat er speelt in de buitenwereld en weet wat de gevolgen zijn als de boel bij een organisatie niet op orde is. Je fungeert als 'het geweten' van de organisatie en ondersteunt daarbij degene die aan het roer z van de organisatie.

Luisteren

Communicatie heeft volgens hen tot doel om

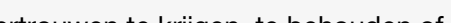

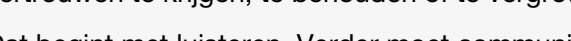
Dat beg

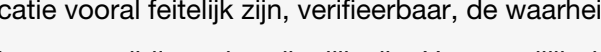
bevatten, tijdig en begrijpelijk zijn. Hoe moeilijk da is, blijkt wel uit de voorbeelden in het boek waarb het organisaties, bewust of onbewust, niet lukt integer te handelen of te communiceren. Je kunt daar als communicatieprofessional wa aan doen. Volgens De Leeuw en Mertons uraagt het een bepaalde mentalitieit en rolopvatting Communicatiemensen mogen best wat kritischer zinn in het spiegelen van de baas, en de voelsprieten wat strakker afstellen. Ook als je dat niet in dank afgenomen wordt. Daarbij zul je aan de slag moeten om anderen te helpen betrouwbaar te handelen.

\section{Gewenst?}

Voor Monique Janssens gaat Maatschappelijk Verantwoord Ondernemen ook over Maatschappelijk Verantwoord Communiceren. Ook zij vraagt in haar witboek aandacht voor de kwaliteit en werkwijze van communicatiemensen zelf. Nudgen, framen, spinnen en zelfs het gebruik van humor kan misschien wel effectief zijn, maar is het ook altijd maatschappelijk gewenst? Hoe alert zijn we op de privacy van anderen en welke ethische waarden hanteren we als uitgangspunten van de afdeling Communicatie in onze organisatie? Janssens nodigt ons uit hierover in gesprek te gaan, met mensen binnen en buiten ons bedrij om te komen tot een maatschappelijk verantwoord beleid voor interne en externe communicatie. Elke organisatie zou moeten vastleggen op welke wijze ethiek een plek krijgt in het communicatiebeleid. Communicatiedoelen moeten niet SMART zijn, maar SMARTER. Naast Specifiek, Meetbaar, Acceptabel, Realistisch en Tijdgebonden ook: Ethisch en Registreerbaar.

Als je erin gelooft dat ie integriteit bij communicatieprofessionals kunt trainen, dan is het vakgebied twee boeken rijker die je daarbij kunnen helpen. Verplichte kost. En als je het uit hebt, kun je he meteen weggeven aan iemand in de bestuurskamer, Den Haag of het Witte Huis. Heel veran woord 


\section{$\star \star \star \star$ Lingua}

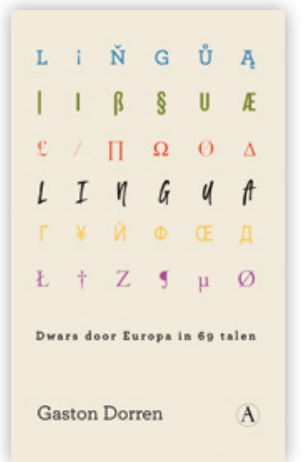

Gaston Dorren

Athenaeum-Polak \& Van Gennep, 2017

978-90-253-0789-9/NUR 320,

357 pagina's, $€ 19,99$

hgua is en heerlik boek voor iedereen die van aal houdt. Gaston Dorren neemt de lezer in korte hoofdstukjes mee door Europa. Van de 69 talen die aan bod komen, heeft hij groepen gemaakt in categoriën als: 'schrif-en spreektaal', 'talen \& hun woordenschat' en 'kant boord \& erger' (dat gaat over de hele kleine talen).

Dorren schrijtt boeiend. Want als je bij het Tiechisch bent angekomen en

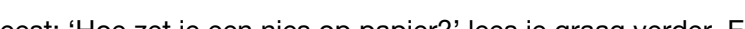
et Ests schrijft, vergelijkt hij dat met het zien van een bekende op tv. Om vervolgens uit te leggen hoe al die Nederlandse woorden toch in het Ests terecht zijn gekomen. En hoe aardig om te weten dat het Italiaans niet alleen verkleinwoorden heeft maar ook vergrootwoorden. En het Schots-Gaelisch biedt hij de helpende hand om de spelling te veranderen.

Dorren besluit ieder hoofdstuk met een woord dat het Nederlands aan die ta heeft ontleend en omgekeerd een Nederlands woord wat door eee an taal is overgenomen. Paella komt dus uit het Catalaans en het Nederlandse woord baggeren heeft via het Duits een heel stel Midden- en Oost-Europese talen bereikt.

\section{Marie-Louise de Jong}

MOET JE LEZEN

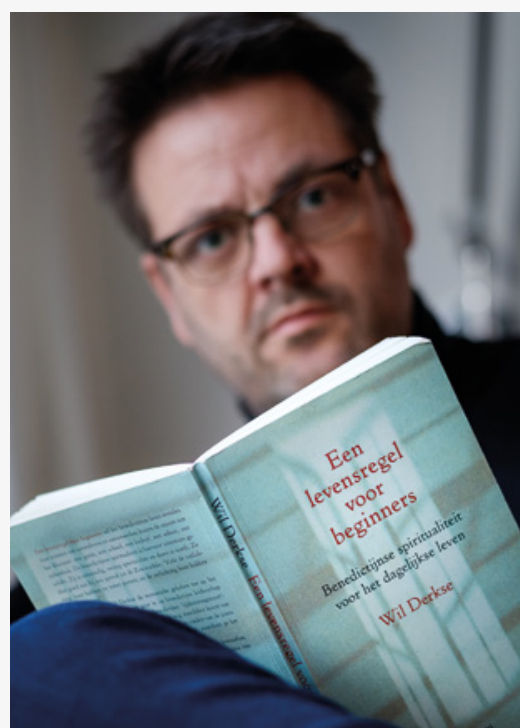

$\star$ Succesvol doelen bereiken

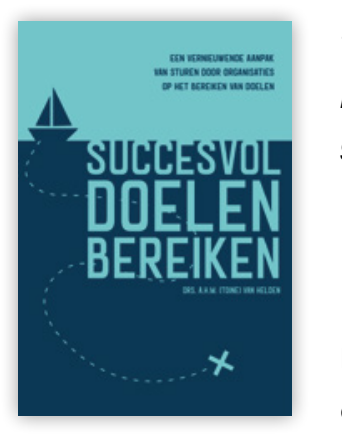

Toine van Helden

978-90-232-5578-9,

152 pagina's, $€ 22,95$

Is er een gouden formule om doelen te bereiken? De auteur van 'Succesvol doelen bereiken' is ervan overtuigd dat die formule er is, hij noemt het zijn

methode. Dit boek is de weerslag van ruim 35 jaar ervaring. Auteurs die op basis van een werkzaam leven leerervaringen delen, daar hou $i k$ van.

Dit boek verbindt veel bekende gedachten tot een praktische handleiding hoe te sturen op doelstellingen. In één zin: het verbinden van doelenbomen met logica, communicatie en mensen als bron van energie. Handig voor wie niet loskomt van de waan van de dag. Nuttig voor bestuurders en wie sparringpartner wil zijn. Toch blijt het boek instrumenteel. Ik mis verhalen over misstappen, dat zou het kleurijiker en vooral overtuigender maken. De auteur stelt communicatie volledig ten dienste van het sturen op doelen. Dat staat mij tegen. Met verhalen kan je niet sturen, zegt hij. Communicatie moet voldoen ann 'verkeersregels', Het is het goed recht van de auteur om volledig overtind a overtugd te zin va mis met het sturen op doolen, dan worden losjes oplossingen gezocht in het menselijk brein. Ook daar mis ik praktijkvoorbeelden. En vind ik het boek eenzijiig.

Peter van den Besselaar

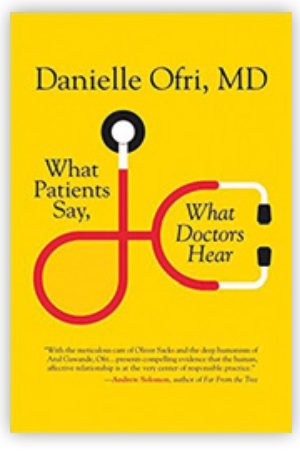

Danielle Ofri, MD,

Beacon Press 2017

"Dokter, ik heb last van minn rug. Ik kan niet

meer fietsen en iets optillen doet pinn." De dokter vraagt na deze twee zinnen: "Wanneer is dat begonnen?". Een dokter onderbreekt een

patiënt na zo'n twallf seconden. De New Yorkse specialist Danielle Ofr schrifitt in What patients say, what doctors hear over de communicatie tussen arts en patiènt. Dit boek is een pleidooi om beter te luisteren. En voor

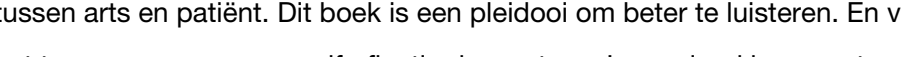

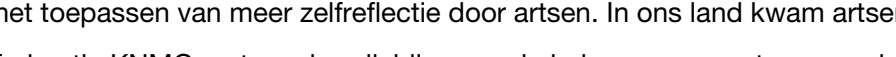
federatie KNMG met een handleiding waarin haken en ogen staan over het opnemen van gesprekken. Veel artsen zijn er niet dol op. Patiënten hebben baat bij het terugluisteren van informatie over de diagnose en behandeling. Danielle Ofri zegt dat dokters verbaasd zullen zinn als ze eigen gesprekken via video-opnames terugzien. Zelf was ze geschokt over gebruik van haar handen "'it's a wonder I didn't accidentally knock any patients of the exam to is een heerlijk boek over interpersoonlijke communicatie, ook interessant voor bestuurders. Voor iedereen die de neiging heeft om snel te oordelen. Met veel humor geschreven.

Peter van den Besselaar $\star$ Radicaal openhartig

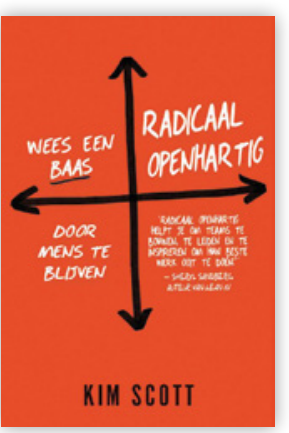

Kim Scott,

A.W. Bruna 2017

78-90-449-7645-8,

299 pagina's, $€ 24,99$

Stel: je bent baas van een bedrijf en krijgt op een dag van tien verschillende mensen hetzelfde artikel, waarin staat dat mensen liever een stomme baas

hebben die zijn werk goed doet, dan iemand die aardig is en incompeten. Dit overkwam Kim Scott en ze schreef een boek over haar nieuwe aanpak. Scott heeft haar sporen verdiend bij Google en Apple. In dit boek deelt ze haar flaters en succesverhalen. Goede bazen crëren een open be

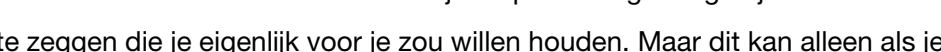
persoonf persoonlijk betrokken bent bij je mensen. Ze vertelt hoe je dit in de praktijk toepast. Dit boek is een aaneenschakeling van anekdotes. Dat geeft je leuke inkijkjes in werksituaties bij grote techbedrijven. Maar dit maakt het boek langdradig. Ook zijn de beschreven situaties niet herkenbaar in onze cultuur. In Silicon Valley is het hilvoorbeld normal om sommige medewerkers te directe aansturing.

Krijg iji signalen dat je als baas wel wat skills kunt gebruiken? Lees dan dit boek. Voor de communicatieprofessional echter geen verplichte kost.

Teunis van Hoffen
Auteur Guido Rijnja

Een levensregel voor beginners oet je lezen volgens Jos Stuar

"Eerlijk gezegd ben ik geen grote lezer. Eerder emand die wordt gegrepen door beeld. Hoe of waar ik het boekje 'Een levenseget voor ( gring het kloosterleven ging en lekker dun was. Hoe dan ok: het heeft me geinspireerd en aan het denken gezet.

Auteur Wil Derkse legt in slechts 124 pagina's uit hoe de Benedictijnse spiritualiteit van waarde ka zinn in het werkzame leven. Derkse, scheikundige, filosoof en als oblaat (leken-pater) verbonden aan de St. Will brordusabdij in Doetinchem wijdt z' regel van Benedictus: de kunst van het aandachtig luisteren. Hij verhaalt over een bezinningsweekend dat hij organiseerde voor ondernemers. De vraag aan de deelnemers was welk voorwerp voor hen goed leiderschap verbeeldt. Derkse zelf kwam met een stethoscoop op de proppen. Volgens hem kan goed iederschap niet zonder goed luisteren. Of beter: ausculteren, zoals artsen het noemen. Tussen geborrel en gerommel, geruis en geklop do signalen oppikken die er werkelijk toe doen.

Goed luisteren is in ons vak essentieel Voor de gelovigen van de Dialoog. Voor de predikers die willen overty Gedrang ding. Hoe vaak moeten Wij hot tussen de regels door lezen? Ons de vraag stellen wat de echte reden is van weerstand en gedrag? Aan ons de taak 'gehoor te geven aan' (Benedictijnse vertaling van 'gehoorzamen') wa het in essentie om draait. Derkse's witleg van de

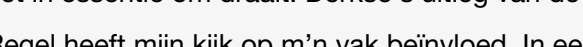
gep epolariseerde wereld schreeuwen organisaties aan toe. De neiging om direct te reageren is groot. Juist dan helpt het om eerst aandachtig e luisteren, te kiezen voor het kleine gesprek en samen te zoeken naar wat verbindt en overbrugt. Introversie als deugd in een ogenschijllijk extravert vak

De Regel leest en lijkt op het eerste gezicht eenvoudig. Dat is bedrieglijk, zeker voor extraverte lezers. Derkse adviseert om de teks vooral 'proevend' te lezen. Want wie goed lees ence te passen in de drukte van alledag, leert al snel hoe ingewikkeld eenvoud kan zijn. Gelukkig benadrukt Derkse dat het een levensregel voor beginners is. Een gevorderd niveau bestaat niet. Wel de aansporing om elke dag opnieuw te beginnen."

Jos Stuart is communicatieadviseur en woordvoerder bij Divosa, de vereniging var leidinggevenden in het sociale domein 


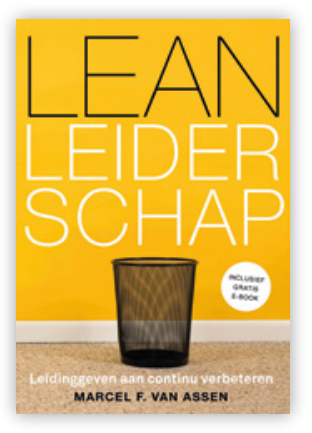

Marcel F. van Assen

Boom 2017

978-90-244-0429-2.

192 pagina's, $€ 24,99$

Een goed leesbaar boek waarin je wordt meegenomen in de rol van leidinggevende in een Lean organisatie. In dit boekt pelt de auteur het contanerbegrip Lean af. Want wat is het? Een toolbox met verbetertechnieken. Lean gaat verspilling tegen. Lean als methode om klantwaarde toe te voegen En Lean is een manier om te sturen op resultaat. Maar Lean werken en Lean mogelijk maken, vraagt om een leiderschapsstijl die een verandercultuur op gang brengt. En hoe doe je dat dan?

Het is mooi om te lezen dat je je als Lean-leider ook, of misschien wel juist moet richten op de zachtere kanten van het managementvak; ontwikkeling, coachen en mogelijk maken.

De auteur vergelijkt in het boek Lean Leiderschap met andere vormen van leiderschap: Tranformationeel, dienend, situationeel, coachend en empowering. En hoewel er zeker overeenkomsten zijn, benadrukt de auteur ook enige verschillen in de diverse stijlen. Naast de nodige theorie maakt de auteur ook de link naar de praktijk en maakt het compleet met do's \& don'ts.

Denk jij bij het woord Lean vooral aan standaardisatie, coachings- en verbeterkata's, dan heb je nog een te beperkte kijk. Voor een bredere kijk vanuit een managementperspectief is dit boek een aanrader.

Maria Harmsen

Toptrends voor ondernemers

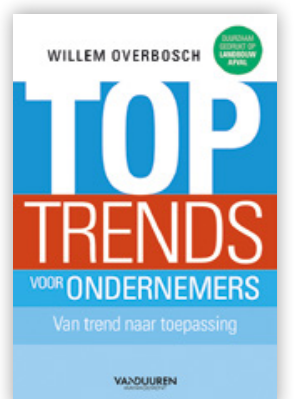

Willem Overbosch

Van Duuren Management 2017

978-90-896-5363-5,

208 pagina's, $€ 24,99$

Je klant is veranderd. Die is digitaal en verwach dat informatie wordt aangeboden op een scherm. Wil bovendien dat alles hier en nu beschikbaar is.

Het zijn uitdagingen, maar het biedt ook kansen.' Willem Overbosch schrift

in zinn boek 'Toptrends voor ondernemers' over de WHY (de achtergronden

van huidige trends), de HOW (hoe pakje vernieuwing aan?) on de WHAT val Nuttig is de focus op Sustainable Development Goals en een dromenvanger-aanpak om hier in je organisatie mee aan de slag te gaan (iedereenondernemen.nl/toolkit). Als hekkensluiter lees je over het Trendcanvas. Dit is een weergave waarmee je trends kiest, kunt beoordelen op waarde voor je klant en kunt uitwerken voor jezelf. Dit doe je aan de hand van de TrendToepasMethode. Als communicatieprofessional ben je waarschijnlijk bij een dergelijk traject betrokken, omdat je weet wat er speelt in de buitenwereld en bovendien een goede vertaalslag van kernwaarden kan maken. Los daarvan vraagt werken met trends om creativiteit, verrassende kruisbestuivingen en brainstorms, waar je wellicht een faciliterende rol kun spelen. Kortom: een aardig boek met een paar toepasbare elementen.

Christel Berkhout

\section{KWARTAALDICHT}

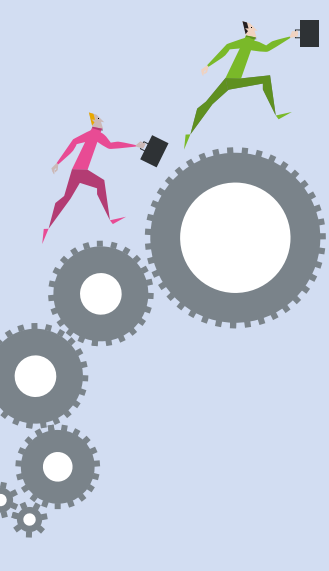

Auteur Guido Rijnia

Middenmanagementblues

Ode aan de scharnieren,

het middenmanagement,

verbindingsofficieren,

de scheerliin van de tent.

Ze boodschappen naar boven

wat op de werkvloer brandt,

zouden graag iets beloven
Boven kan hen gebruiken,

als intermediair,

niet zo maar doorgeefluiken

toch voelt het zelden fair.

Best knap dat heen en weren

zo goed als dat dat gaat,

blijven communiceren,

leiderschap in spagaat.
OUBLIQUEST

Leene Communicatie
Conmunicatiucaureau Podium
Maatschap voor Communicatie

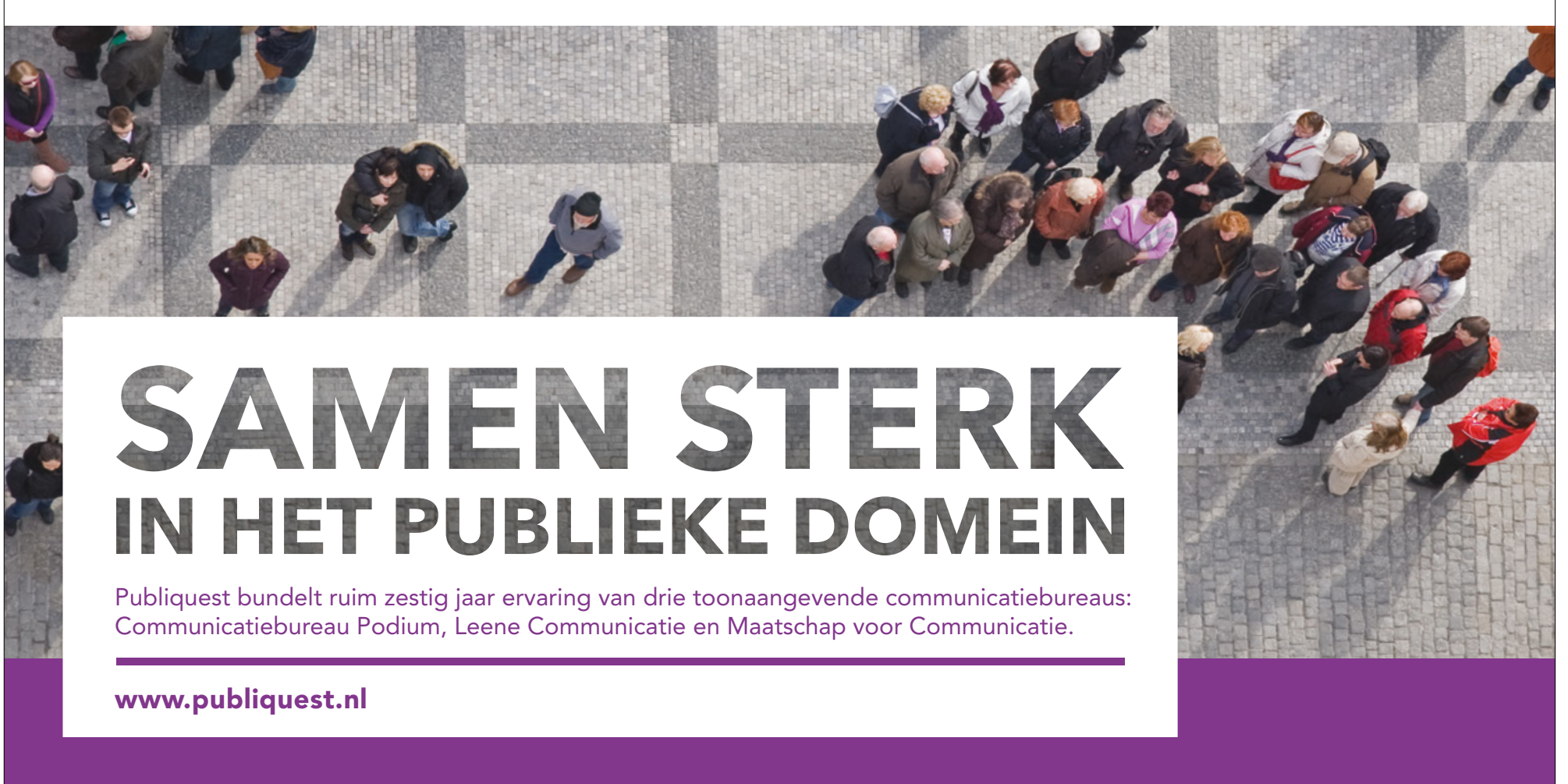

\section{Communicatieprofessionals maken indruk mett}

Interne of externe online community starten?

Wil je veilig kennis en ideeën delen met collega's, klanten, inwoners, leden, experts of partners? Wij bieden het meest flexibele community platform om samen snel aan de slag te gaan. Mett voldoet aan de AVG, is volledig responsive en webrichtlijnen-proof.

Bel ons op 0302920701 voor een afspraak en een demo.

In 30 tot 60 min brengen we je vraagstelling in kaart en je oplossing in beeld.

mett.nl 


\section{CIW, wat bedoelen}

\section{ze daar mee?}

andere Communicatie- en Informatiewetenschap-

pen (doorgaans aangeduid als $\mathrm{CIW}$ ). Wat is het

verschil? In elk geval dat de eerste onderdeel is

van de faculteit Sociale Wetenschappen en de

De vraag die voor ankomende studenten relevent

lijkt (of zou moeten zijn), is of je bij CIW andere

kennis en vaardigheden opdoet dan bij een studie

Communicatiewetenschap die je ook aan diverse

Nederlandse universiteiten kan volgen? En of je $\mathrm{n}$

een studie Communicatiewetenschap een ander

type communicatieprofessional bent dan na een

studie CIW. Die vraag lijkt trouwens net zo goed

relevant voor werkgevers: wat voor type profess-

onal heb je nodig met het oog op jouw specifieke

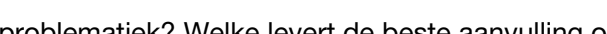

het bestaande team?

Maar wat is dan het verschil tussen beide varian-

Speelt ook binnen de 'inner circle' van degenen die aan universiteiten werkzaam zijn in dat vak.

Hij komt ook expliciet aan de orde in de inaugu-

rele rede die Hans Hoeken op 2 november 2017 uitsprak bij de aanvaarding van de leeropdracht Communicatie- en Informatiewetenschappen in Utrecht. ${ }^{1}$

Komt het verschil in herkomst - uit respectievelijk de sociaalwetenschappelijke en de geesteswetenschappelijke variant - tot uiting in de onderwerpen die bij CIW onderzocht en gedoceerd worden? In een helder en zowel lezens- als aanbevelingswaardig betoog zet Hocken uteen wat die ondemerdig berog ze Hoeken penzfn zer weap dat als volgt samen: "In mijn visie richten het onderwiss en het onderzoek binnen Communicatie- en in en verklaren van communicatie en mediagebruik vanuit een functioneel kader." Het gaat dus niet om communicatie op zichzelf, maar on de functe wil de communicator ermee bereiken: overtuigen/beinvloeden, mensen aan het denken zetten, etc.. "De mate waarin mensen tevreden zijn over hun communicatie of mediagebruik, leiden ze af uit hun welbevinden." Draagt

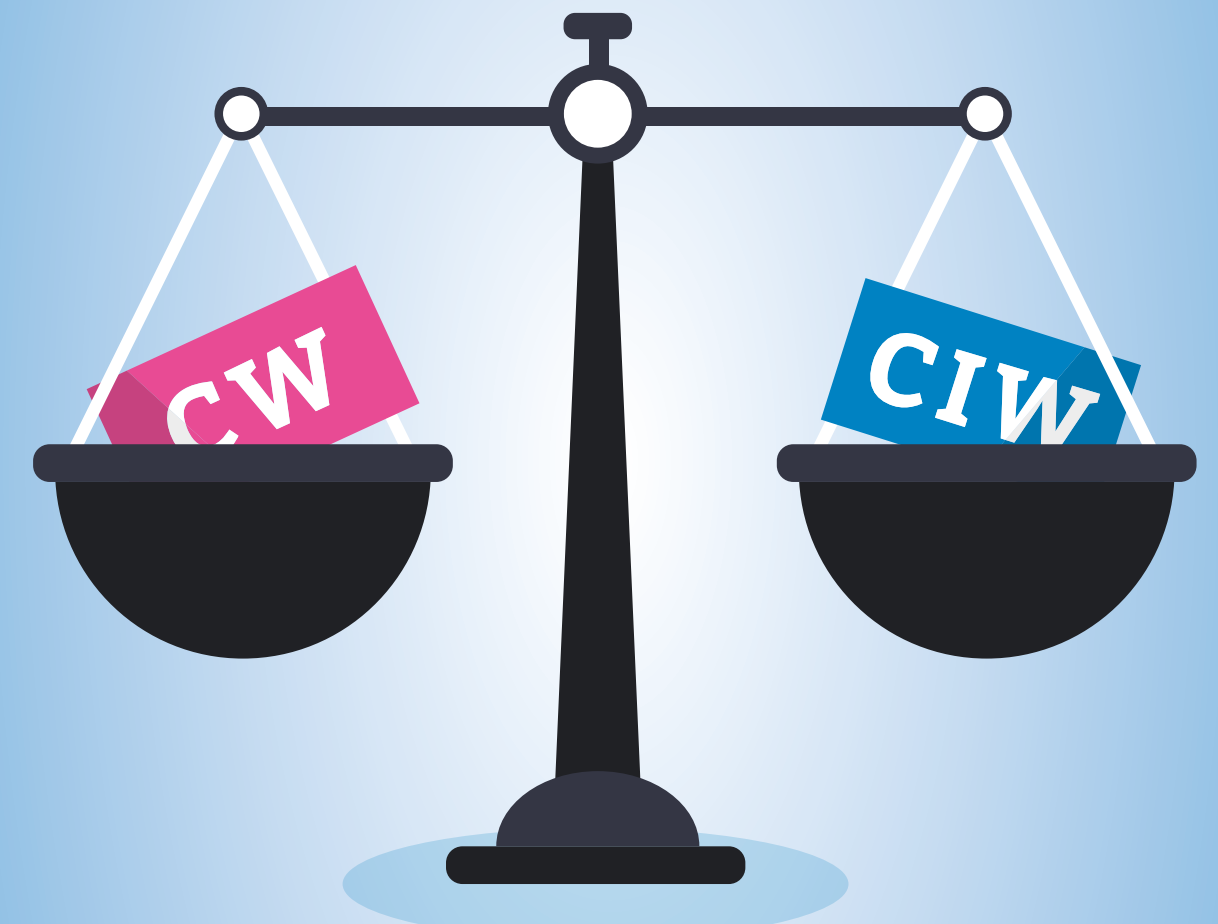

ming, of voorziet het in onze behoeften? Daarbij spelen ook 'kennis en waarden, de mogelijkheden van het medium en cultuur' een wezenlijke rol.

Verschillende faculteiten, verschillende onderwerpen?

Maar dat doet de sociaalwetenschappelijke

Communicatiewetenschap ook. Ook daar word de relatie mens-media bestudeerd, ook in een functioneel kader, bijvoorbeeld beïnvloedende communicatie, communicatie over leefstij, etc. In de keuze van de fenomenen die men bestudeert dus net Jo zon den da net het dan in de orke tenschappelijke communicatiewetenschap zich primair richt op communicatie in een maatschappelijke context, of in de manier waarop mensen elkaar beiinvloeden. Maar dat blijkt CIW dan weer net zo goed te doen. CIW gaat in de definitie van Hoeken om communicatie in een functioneel kader', niet over communicatie als fenomeen. Bestudering vancortur overigens niet zon gex ide zifn. ren ren heel wat af met onszelf. In ons hoofd, soms ook hardop. Bovendien is er heel wat communicatie die nergens echt over gaat, maar meer een vorm van contact maken is: praatjes in de trein over het weer of een vertraging, gesprekken op veriardagen, etc. Whan doen we dat?

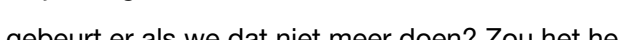
pen als we ditus mer zoun do pen als we dat uis meer zouden doen. commumaken? Het lijkt waarschinlilik dat het - in lijn > 
'De sociale

wetenschappen

zoeken naar

regelmatigheden

in gedrag, in de

geestesweten-

schappelijke

traditie gaat het

om interpreteren' met Allports contacthypothese ${ }^{2}$ - meer respect voor elkaar en elkaars mening in de hand werkt. Met andere woorden meer harmonie bewerkstelt?

Andere methodologie?

et verschil tussen de geesteswetenschappelijke IIW en de sociaalwetenschappelijke Comm nicatiewetenschap lijkt dus niet te zitten in de fenomenen die men bestudeert en ook niet in het functionele kader waarbinnen dat plaatsvindt. Zit het dan in de methode die men gebruikt? Dat zou Jerwach vaw bin ben Gesesw van CIW birnnon de Goosteswetenschappen. In geval sinds de jaren '80 van de vorige eeuw zijn in de sociale wetenschappen andere methoden en technieken dominant dan in de geesteswetenschappen. De sociale wetenschappen zoeken naar regelmatigheden in gedrag, bijvoorbeeld hoe mensen reageren op een sociale beïnvloedings-

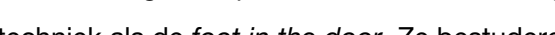
of, in hoeverre en in welke situaties die techniek werkt. Daarbij maken ze gebruik van experimenten en statistische toetsingstechnieken. Die heb je ook nodig als je met een zeer grote mate van waarschijnlijkheid wil bewijzen dat zo'n techniek effectief is in een bepaalde context. Dus of er werkelijk sprake is van een gedragsregelmatigheid. In de geesteswert interpreteren. Er valt in historisch onderzoek of in Iteratuurstudies ook weinig of niets te bewijzen. Je kan alleen aannemelijk maken dat er een verband is tussen diverse literaire teksten, of waarom iets in het verleden gebeurd is. Bijvoorbeeld dat het aannemelijk is dat het Romeinse Rijk niet ten val kwam door decadentie, maar doordat uit verre geber -

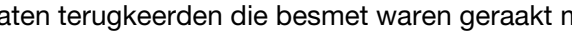
het land van oorsprong onbekende virussen, waartegen men nog onvoldoende resistentie had opgebouwd. Maar is die interpretatieve invalshoek aanwezig bij CIW? lk meen van niet. Men toetst ook daar onder experimentele condities, met behulp van statistische technieken. Men zoekt ook daar naar regelmatigheden in gedrag en beleving.

\section{Discussie over wat CIW is}

Is het erg dat er geen essentieel verschil valt te ontdekken tussen de geesteswetenschappelijke CIW en de sociaalwetenschappelijke Communicatiewetenschap? Eigenlijk niet, lijkt me. Maar waarom hecht CIW dan zo aan die positionering? Het is een vreemde contradictie: men wil zich onderscheiden, maar in de praktijk doet men da

CIW heeft nog flink werk aan het onderbouwen van haar specifieke, eigen plaats. Hoeken zegt tegen zijn CIW-vakgenoten in den lande: "IK zie uit naar een constructieve discussie over wat CIW is." I ken benieuwd naar de uitkomsten van die discussie.

Onbegrijpelijk is waarom CIW nergens merkbaar interactie heeft met een zusterdiscipline binnen de geesteswetenschappen, de filosofie. Denkers als Wittgenstein, Foucault, Lyotard en Derrida hebben fundamentele problemen van menselijke communicatie aangesneden en verkend - zoals groepen die dezelfde taal spreken maar elkaars communicatie absoluut niet begrijpen: de boodschap word gehoord, maar dringt absoluut niet door. Dat is een fundamenteel maatschappelijk probleem dat dringend de aandacht van de communicatiewetenschap nodig heeft. Misschien een moo profileringspunt voor CIW?

Literatuur

Hans Hoeken. Communicatie in de $21^{\circ}$ eeuw. Utrecht 2017

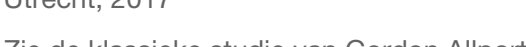
The nature of prejudice (1954). Op individuee! niveau blijken contacten vaak effectief.

\section{Net zo allround als Sven Kramer}

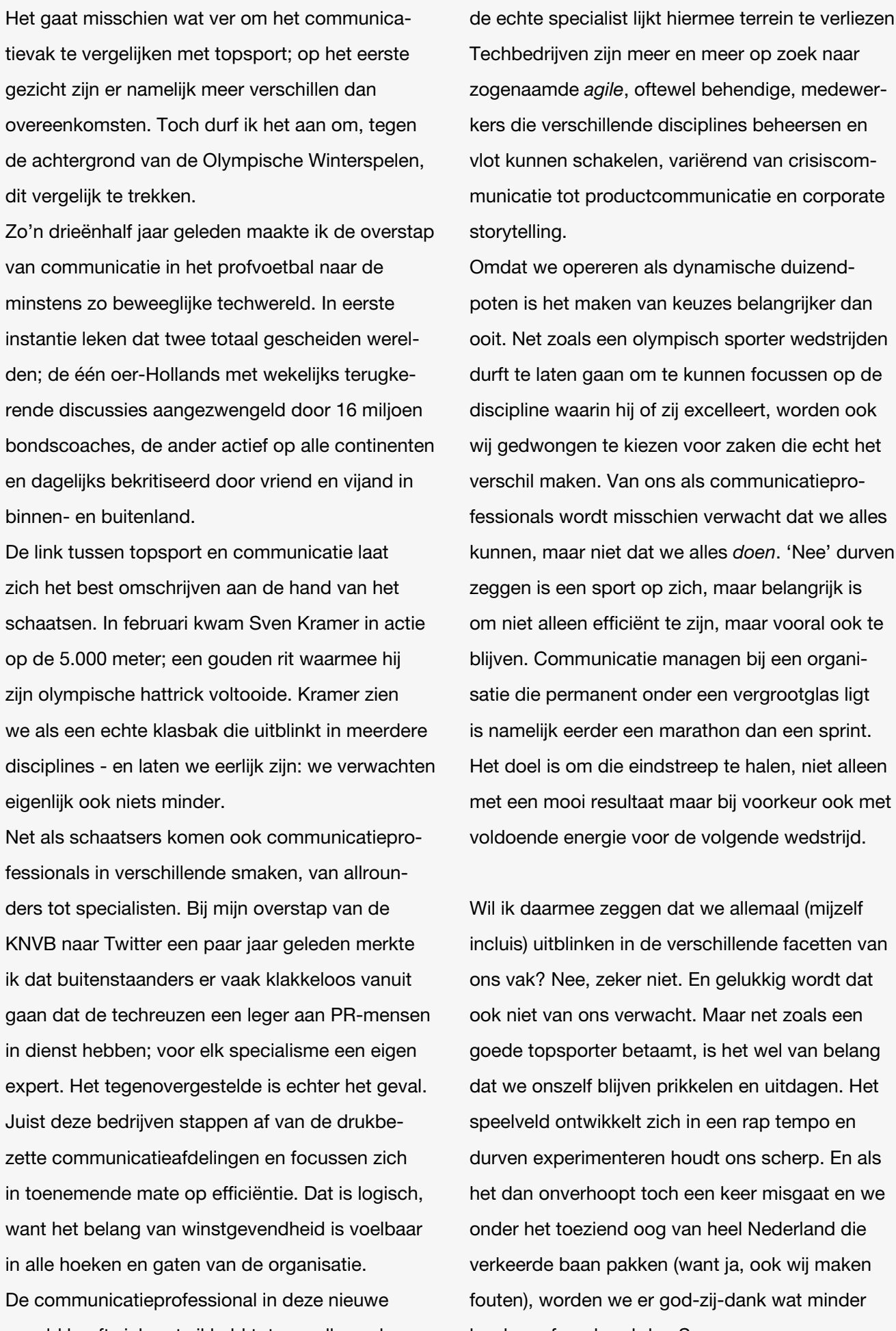

Het gaat misschien wat ver om het communicagaan dat de techreuzen een leger aan PR-mensen van keuzes belangrijker dan ken die echt het op zich, maar belangrijk is doel is om die eindstreep te halen, niet alleen

Wil ik darme zegon dat we allemaal (mizell ch in een rap tempo en hard op afgerekend dan Sven.
En het stokje gaat naar..

De estafette is een column die elke keer door een andere persoon geschreven wordt. Marloes van der Laan geeft het estafettestokje door aan Hans van Kastel woordvoerder van Schiphol.

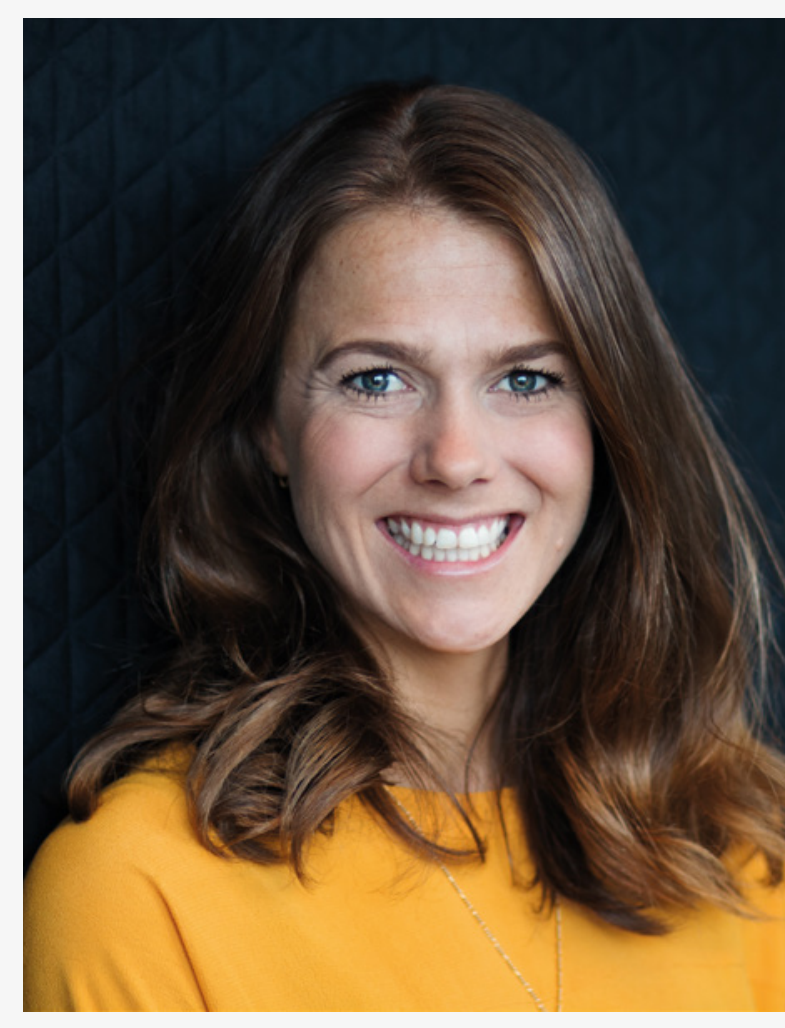


markante

Nederlanders

/ markante

beroepen /

gemene deler:

communicatie

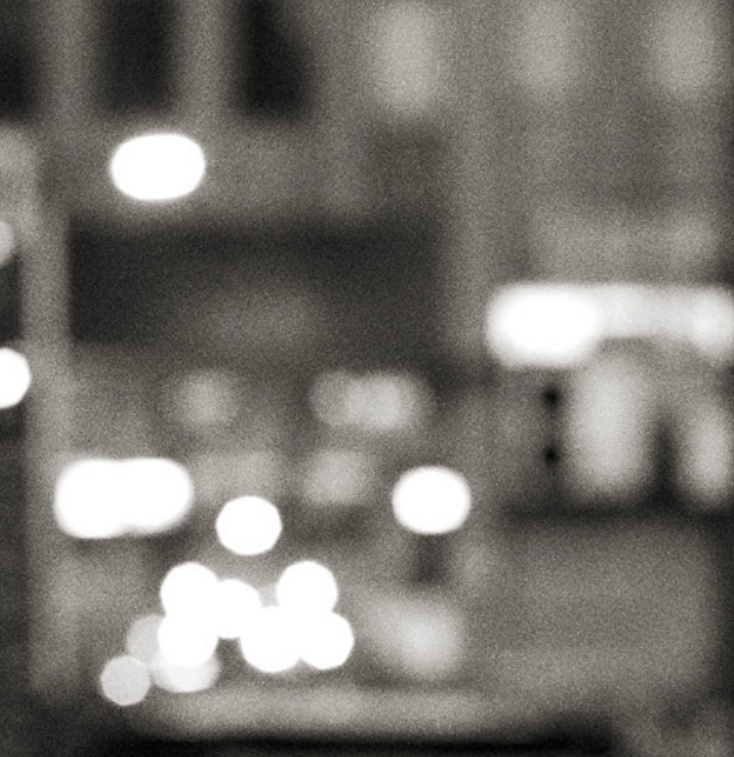

릉

\section{Het beste van}

\section{twee werelden}

$\mathbf{R}$

obert van der Kroft is al 43 jaar de tekenaar van Sjors en Sjimmie en Claire tekent hij al bijn dertig jaar. Hij pleit voor een opwaardering van de strip. Van zinloos tijdverdrijf voor kinderen tot volwaardig medium voor volwassenen. Het kan zelfs een gewaardeerd onderdeel worden van het totaalpakket aan middelen die de (communicatie)professional gebruikt: "Strips combineren de sterke punten van tekst en beeld en kunnen zo een gecomplceerde boodschap heel eenvoudig overbrengen."

"Tekenen heb ik gedaan vanaf het moment dat ik een potlood vast kon houden. Ik denk dat hierin de invloed van mijn vader zichtbaar is. Hij was reclametekenaar en werkte vaak thuis. Papier was altijd genoeg voorhanden, dus ik tekende me suf. Nou is het zo, dat je de meeste dingen leert door ze vaak te doen. Of het nou fietsen is of zwemme of seks. Bij tekenen is dat niet anders. Al moet je het ook nog eens echt heel leuk vinden, want er is geen goed onderwis in. Je tekent weleens een uurtje op school bij handenarbeid of zo, maar iets als tekenvaardigheid bestaat niet.

Twee dingen zinn dus belangrik voor een zith The dich on twaalf oud zijn, kun je niet zeggen of iemand een geweldige tekenaar zal worden of niet: tekeningen van kinderen van een jaar of zes zijn allemaal ongeveer even slecht. Maar als iemand er echt plezier in heeft en aanleg heeft, dan kun je, het tweede belangrijke punt, dat zien als je goed kijk. Neem minn eigen tekeningen, die zijn net een jaartje minder slecht dan van leettidsgenootjes. Het lijkt nog steeds nergens naar, maar qua nivea loop ik een jaar voor op de andere kinderen. Als ouders of leraren dit aanwakkeren, kan iemand zich ontwikkelen tot een goede tekenaar. Bij mij was toevallig mijn vaders werk de aanjage."
Van Donald Duck tot Sjors en Sjimmie "k heb welgeteld zeven weken op de Kunstaca demie gezeten. Drie weken in het eerste jaar, waarna ze me doorstuurden naar het tweede jaar. Daar vond een leraar minn werk zo goed, dat hij aanraadde bij een uitgeverij langs te gaan. Ik stapte binnen en ze zeiden: 'Oh tof werk. Je kan morgen beginnen bij de Donald Duck.' Toen ben ik dus maar met die academie gestopt. Ik maakte hoofdverhalen in het weekblad en kleinere verhaIen als De Grote Boze Wolf en Knabbel en Babbel.

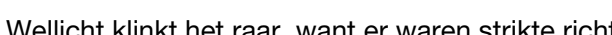
We lin hii kon lachen, maar daar heb ik echt héél goed leren tekenen. Dingen als de opbouw van een verhaal, de opbouw van figuren, cameraposities en dergelijke. Alles om een strip te maken, heb ik bij het vrolijke weekblad geleerd. Het klinkt als een jongensdroom mear het is uit eindelik weini is de pay-of Door Wa Disey. Dus Ton . D strip mocht gaan maken, (a) karkaturaal tot realistisch. Dat was belangrijk voor mijn eigen stij, die zich later vertaalde in Sjors en Sjimmie. Die strip stamt uit de jaren twintig en ik mocht hem in 1975 nieuw leven inblazen. Het was van oorsprong een gagstrip, dus zo'n strookje in de krant met een grapje. Ik heb er met de scenaristen Jan van Die en Wilbert Plijnaar een moderne invulling aan gegeven. Die twee belhamels zijn aan me blijven kleven: ik ben nu al 43 jaar de tekenaar van Sjors en Sjimmie. Ik heb een geweldige samenwerking met Jan en Wilbert Die laatste zei, toen ik met de strip begon, glashard : 'Robert door het anders Tre begn, glasher te vertellen, word je strip beter.' En de redactie van het blad waar de verhalen in verschenen, gaf Wilbert de kans het dan ook maar beter te doen. We hebben de strip in al die jaren volledig naar onze hand gezet. Het speelt zich eigenlijk af op Schiermonnikoog, maar wij kwamen alle drie > 
lit Rotterdam dus ook de strip verplaatste zich langzaam naar een grote stad. Het werd een heed hippe strip waar een metro in verscheen en de tram, er zat graffitit in en skateboarden. Het was zo succesvol dat het hele tijdschrift naar Sjors en Sjimmie vernoemd werd. Daarnaast kregen we de vraag van het Vlaamse vrouwenblad Flair of we ook voor hen een strip wilden maken. Mooi hoe dat tot stand komt: het zoontje van de hoofdredactrice was fan van Sjors en Sjimmie. Dat leidde tot de strip Claire."

Helder en toegankelijk

"Qua beeld en opbouw speelt Claire sterk leentjebuur bij Sjors en Sijmmie. Het zin beide korte trips met vel phaties en teksten. De meeste stins strips zinn bjna getekende Hilms. wisselende cameraposities en perspectieven, inzoomen en uitzoomen, vaak ook kaders van verschillende grootte op één pagina. Ik ben teruggegaan naar de opbouw van Sjors en Sjimmie uit de jaren dertig. Toen waren er nog bijna geen films. De strip is dan ook veel meer opgezet als toneelspel. Je leest het alsof je in het theater zit. Het toneel is altijd op dezelfde afstand, je hebt altijd dezelfde camerapositie en een vaste kadering. In mijn strips is dat niet anders. Zeer klassiek, maar dat heeft zijn voordelen en daarmee komen we ook op de link tussen strips en communicatie. Mijn strips ziin heel rustig om naar te kijken, ik wissel zelden van perspectief. Dat makt het helder en duidelf. Zerer vor mensen die niet fervent strips bzen, Zeker voor mansond die net ten ent strips lezen,

Daarnaast kun je het verhaal ingewikkeld en snel maken: je kunt veel tekst kwijt en je kunt sprong in de tijd maken. Als Claire op het ene plaatje zegt dat ze de volgende ochtend een stoel gaat kopen, kan ik haar op het volgende plaatie een winkel ten lopen met een stoel in har hand Dan is ha rach gewe zest, is en ze heeft betaald. Voor de kijker is dat volstrek logisch omdat je hersenen die tussenliggende periode invullen

Volgens mij is dat een techniek die je in communicatie ook goed kan gebruiken. Mocht je er een soort wetmatigheid van willen maken, dan is dat: houd alles rond je boodschap heel rustig, dan kun je de boodschap zelf heel ingewikkeld maken. En je kunt in de boodschap heel veel informatie weglaten die je publiek zelf invult. Door die rust weten de mensen waar ze aan toe zijn en waar ze welke informatie kunnen vinden. Dat is wat ik in miin strips ook doe en darmee hab ik per ongell een van de meest die er bestan in Nodeland en Vianderik enaars die deze klassieke opbouw nog toepast in zijn werk."

Het beste van twee werelden

"De kracht van het beeldverhaal is niet te onderscharten, al gabeurt dat in ons land wel Hier he se de stip con Kinderik imago, govoed door mensen de niet verder komen dan de smurfenpoppetjes bij de supermarkt, Suske en Wiske of Donald Duck. Op zich mooie strips, maar er is zoveel meer. In de VS en Japan zijn strips heel groot en in een land als Frankrijk wordt de strip de negend kunst genoemd, iets wat het medium meer eer aandoet dan de beperkte blik die in Nederland overeerst. Kijk alleen a nar graphic now overneerst. Kj) alleen al naar graphic novels waarin zeer volwassen thema's aangeboord worden. is zelfs een journalistiek genre, graphic journalism wat bij ons totaal onbekend is. Guy Delisle die zijn belevenissen in landen als Burma en Israël vastlegt in stripvorm of Joe Sacco die vertelt over zijn tijd in de enclave Gorazde tijdens de oorlog in Bosni: Darbij zie je de kracht van strips

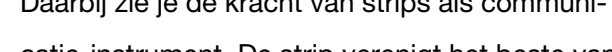
catie-instrument. De strip verenigt het beste van twee werelden. Sommige dingen kun je beter in tekst vangen, neem 'een gevoel van rechtvaardigheid'. En andere dingen zijn juist beter te vatten In een beeld. Het interieur van een huis bijvoorbeeld. De strip is de tussenvorm tussen die twee. Neem 'een gevol van eenzamisid'. Je kunt een man alleen in de woestin zetten maar ook in aleeninde woestin zeten mar ook in de stad kunjo zj, enzan zet teksballonnetje zet je zijn abstracte gedachten uiteen. Zo combineer je beide communicatievormen tot een krachtig beeldverhaal waarin tekst en beeld elkaar versterken. De tekeningen van Joe Sacco geven op veel indringender wize de situatie in ?

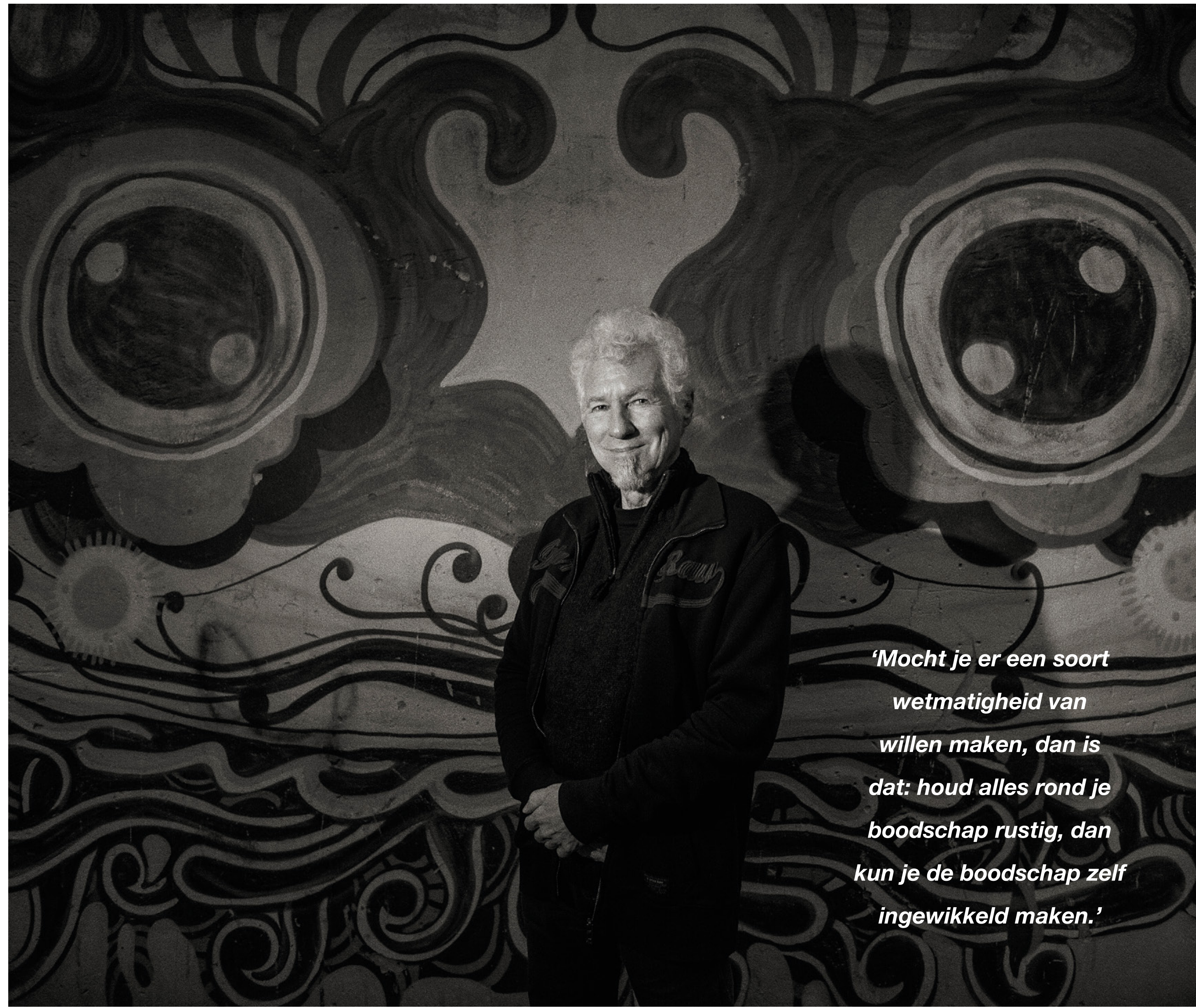

C\#1 - MAART 2018 

nistische regimes van de Sovjetunie, China en Noord-Korea gebruiken de tekening om hun boodschap meer kracht en vooral dramatiek te gever. Dat zijn zeer krachtige communicatiemiddelen."

Doelgroep én onderwerp

"Dit zijn natuurlijk nogal beladen vormen van illustreen, zeker als het over de propaganda van meer totalitaire regimes gaat. Maar het basisprincipe is niet anders dan in strips. Bij een goede strip kunnen mensen zich verplaatsen in de personages, Wat Wenor zorg da de bods Kijk naar Sjors on SIm mile, bedoeld voor jonge tjes van een jaar of vijftien, en Claire, bedoeld voor vrouwen van rond de dertig. Dat zie je in onderwerpen die ik behandel en de verhalen die vertel. Ik verplaats me in de doelgroep, wie moet dat niet, en breng het verhaal in woord en beeld op een passende manier. Zo is de relatie met $m$

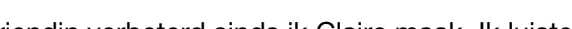
zo goed en onthoud het ook nog, grapt zij dan. Zonder gekheid, je hoeft geen cowboy te zijn om geloofwaardige verhalen over cowboys te maken. Karl May heeft nooit één voet in de VS gezet maar schreef wel de beroemdste boeken over indianen en cowboys ooit. Het gaat erom je in het leven van
列 de doelgroep voor gen te houden. Kijk twee kanten op: leef je in de boodschap in en doorgrond de doelgroep die je vergt veel onderzoek. Vergelijk et met muziek maken voor een volle zaal mensen. Het is leuker als iedereen uit zijn dak gaat, dan wanneer ijj je ingewikkelde eigen ding staat te doen en de zaal staat te wachten tot je klaar ben. het geheim van succes, denk ik. Of je nou André Hazes heet of Iggy Pop, zij luisteren goed naar hu publiek. Zij hebben de focus om te doen wat zij zelf graag doen op een manier die aanspreekt bi het publiek dat ze willen bereiken. Benader jouw boodschap vanuit het perspectief van je publiek.

‘Kijk twee kanten op: leef je in de boodschap in en doorgrond de doelgroep die je wilt bereiken'

Overal aanwezig

"k denk soms dat iedereen die in communicatie werkt, tenminste één keer een goed stripboek moet lezen. En als je dan één boek leest, duik dan eens in de Amerikanse strip Maus van A Spiegerm, envera

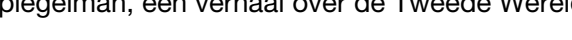
oorlog waarin nazi's letterlijk ratten zijn. Keihard en indringend, maar omdat het is getekend, blijf lezen. Foto's uit die tijd zijn te gruwelijk om naar te kijken maar de strip van Spiegelman blijf je lezen vanwege die parodie met ratten. Terwili je dus och doordrongen moeilike en pintre eptode un onze geschedo- n int leren als communicatieprofossional: het narratieve en beeldende. Verge niet dat de strip overal om ons heen aanwezig is. Van handleidingen van de lkea tot tekstballonnetjes die WhatsApp gebruikt en van striphelden die figureren in de bioscoop tot de visualisatie van computergames en infographics die je in tijdschritten terugvindt.

De strip op zich heeft een imagoprobleem. Ik probeer daar met collega's wel wat aan te doen, via het CrossComix stripfestival bijvoorbeeld, waar als het Natuurhistorisch Museum en de Kunsthal Roter. We late zien dat stipse rotsenten (n) dagelijkse straatbeeld. In de Rotterdamse Witte de Withstraat zijn de antiterreurbakken beschilderd door stripmakers en graffiti-artiesten en er is een jazzroute door de stad die langs getekende plakkaten van befaamde Rotterdamse jazzmusici

Langzaam zie ik wel verandering optreden in de waardering voor strips. Mijn collega Aimee de Jongh is bijvoorbeeld voor NRC Handelsblad naar Lesbos geweest. Ze mocht vluchtelingenkampen op het eiland bezoeken en er naderhand een beeldverhaal over maken. Dan zie je weer wat de toegevoegde waarde van de striptekenaar

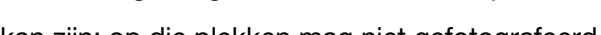
kan zjn. op die plokken mag niengerotografeerd worden. Zil schetst van het leven in de kampen en zij beschrijtt wat die mensen meegemaakt hebben. Een verhaal da niet op een andere manier zo indringend gebracht kan worden.

Ook in het bedriffsleven komt de strip langzaam op, maar je moet het leren zien als strip. Je kont vast wel het geteke ing of bisertonst, its wat de la opkomt bij bedist. Das is ne jarten sterk Da is niet anders dan een strip. een compleet verhaal in één grote tekening. De grap is, dat bijna iedereen in zijn jonge jaren strips gelezen heeft, maar dat de meesten vergeten zijn ermee door te gaan en het dus ook niet meer als zodanig herkennen. In de snelle wereld waarin wiij tegenwoordig leven, kan de strip juist ren informie overteb (n) en Janneke-taal toen hij minister-president was. De strip is daar wat mij betreft een mooie doorvertaling van." • *alles

\section{begint met}

een idee.

\section{carenza*}




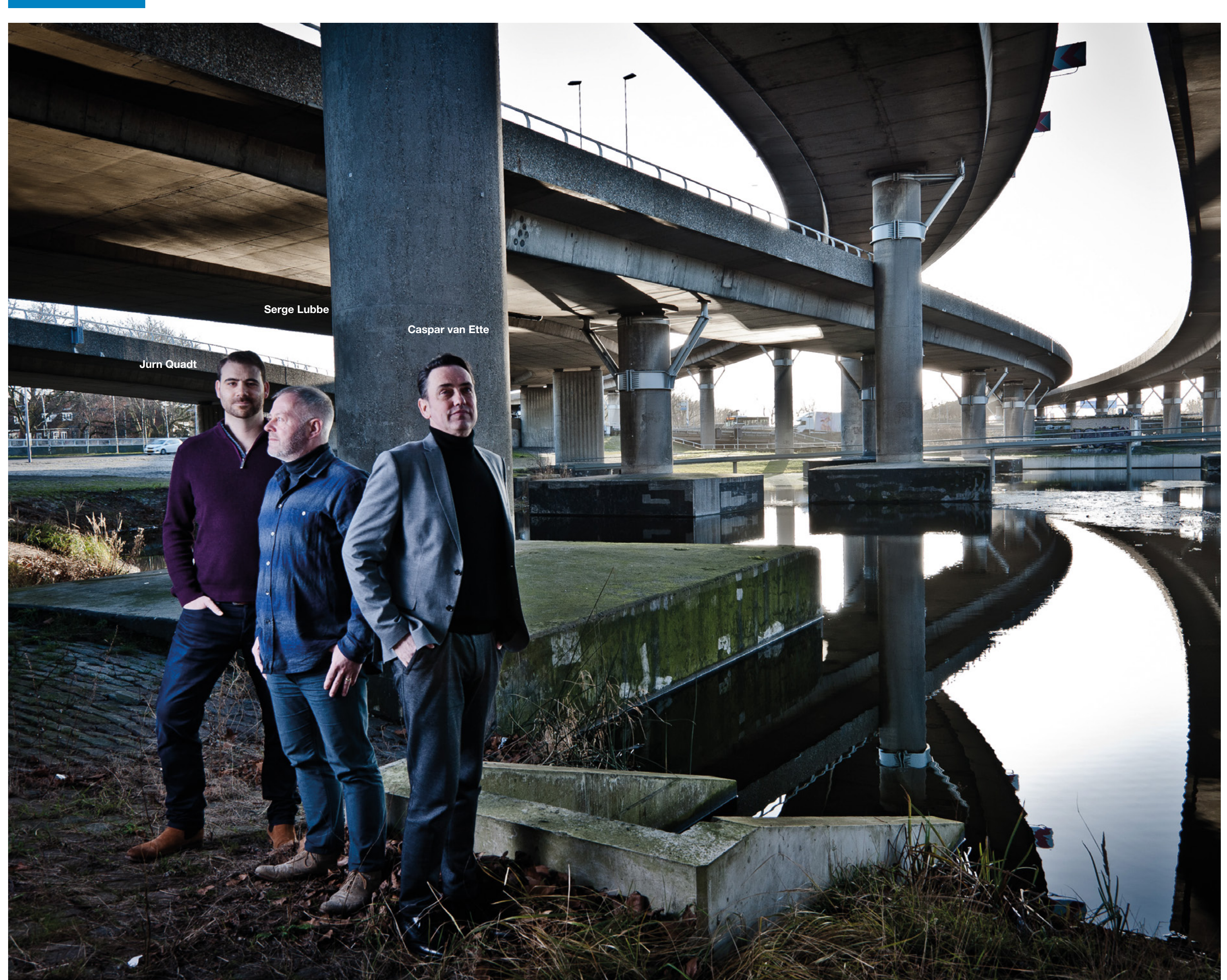

Auteur Marjolein Rozendaal

Perron 14

Werken voor de samenleving, da's andere koek

Sociaal-maatschappelijke communicatie, bestaat dat? Ja, en bij driemansbedrijf Perron 14 in Rotterdam weten ze er alles van. Schouder aan schouder met opdrachtgevers in het publieke domein werken ze an mocie odrather won Cond wonen. Commanicat mer mpact op het leven van gewone mensen dus. En dat doen ze nuchter, duidelijk én effectief.

Serge Lubbe: "De participatiesamenleving is een ingewikkeld concept, en dat moet je doen met elkaar. Waar gaat dat precies over? Het antwoord komt uit op het snijlak van organisatie, communicatie en beleid."

Druk met: Voor verschillende institutionele organisaties en lokale, gemeentelijke en landelijke overheden werken we aan opdrachten die we hopelijk nog lang en vaak zullen doen. Als communicatiebureau hebben we verschillende rollen, een daarvan is het overbrengen van informatie aan het publiek.

Is van mening dat: Je bent niet alleen maar de brenger van een boodschap, maar ook de ophaler van informatie als input voor beleid. Ik denk dat communicatie al onderdel moet zin van de ontwikkeling van plannen en beleid. Op het her Ing tussonn da be dis doet iedereen wil, kun je veel betere dienstverlening leveren.

Bijzonder: In onze opdrachten laten we de publieke ruimte onderdeel zijn van de communicatie. Naast de inzet van traditionele communicatiemiddelen organiseren we oploopjes en evenementen met bijvoorbeeld preventieteams in de winkelstraten. De besturlilik verantwoordelije politici laten zich hier meestal ook graag bij zien. Dat maakt deze acties heel effectief en waardevol.

Krijgt energie van: Er leven veel ambities bij alle verschillende partijen om verbetering aan te brengen. Dat omvat meer dan alleen communicatie, maar het heeft ook te maken met de definitie van communicatie. Je kunt niks doen zonder je te realiseren dat iedere stap die je zet een signaal overbrengt. Als $j$ e het niet goed communiceert, wordt het nooit een succes. 


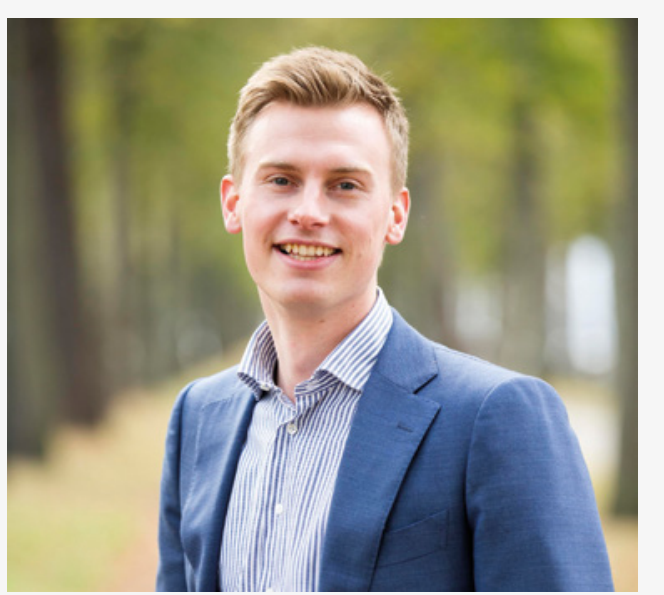

Specialist of generalist?

Je vak bijhouden. Ik verbaas mij altijd over die uitdrukking. Als je je vak probeert bij te ouden, hol je dan niet achter de werkelijkheid an? Vernieuwing in communicatie vindt n-

melijk vooral plaats aan de grenzen met andere disciplines. De invloed van IT, bedrijfskunde e psychologie is gigantisch. Mijn overtuiging is daarom dat young professionals van deze tijd verder moeten kijken dan alleen communicatio.

De laatste jaren ontstaat er steeds meer vraag naar professionals met een T-profiel. Zij ziin zowel specialist als generalist. De vertic streep van de T symboliseert een diepgaande toewijding, specialistische expertise en vaardighe den in hun eigen vak. De horizontale streep van de T visualiseert de brede basis waarop hun profiel is gebouwd en waarmee zij zich kunnen verbinden met professionals uit andere disciplines.

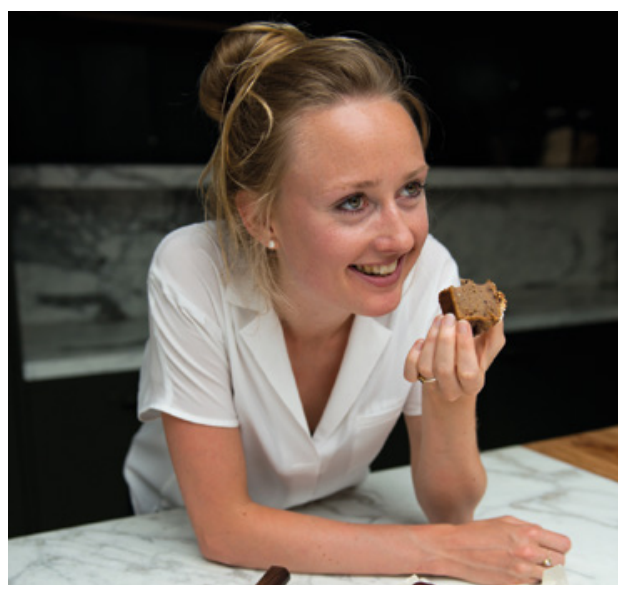

Isabel Boerdam

studeerde Tekst \& Communicatie aan de Universiteit van Amsterdam. In 2013, tijdens haar master, startte ze haar blog dehippevegetarier.nl dat inmiddels door 100.000 unieke bezoekers per maand wordt bezocht. Haar blog leidde in april 2016 tot haar gelijknamige boek en heet envor enoor gezorgd da ze nuvan haar pass haar werk kan maken. Daarnaast werkt ze als freelance PR- en communicatieadviseur bij Omnicom PR Group in Amsterdam. Van 5-11 maart 2018 lanceerde Boerdam de eerste editie van de Nationale Week Zonder Vlees in Nederland
Heel Nederland flexitariër door pr nieuwe stijl

Blogs, influencers en campagnematig werken: workshops. Het uitgeven van minn boek was een het is vandaag de dag niet meer weg te denken hoogtepunt."

it je communicatiemix toat stan witje PR-

the jecolo

en PR-consultant Isabel Boerdam, oprichter

van het foodblog De Hippe Vegetariër en

initiatiefnemer van de eerste Nationale Week Zonder Vlees?

\section{Opstarten van een blog}

Boerdam: "lk ben al sinds mijn negende

Begetaiti ut agen beseging onda vegetarer, reallsoord dis de koe in do weid dezulde koe was als op mijn bord. Tijdens mijn studententij merkte ik dat ik een andere visie op vegetarisch eten had dan veel mensen om mij heen. Voor $\mathrm{mi}$ was en is vegetarisch eten heel lekker, creatief, gezond, goed voor mezelf en de wereld om me heen. Terwill voor vel mensen vegetarisch eten geassocicer geassocieerd werd met een soort van eetreligie en geitenwollensokken. Dus ik wilde graag $\mathrm{m}$ 'hippe' vegetarische inspiratie delen. Daarom startte ik in 2013 mijn blog 'De Hippe Vegetariër' Inmiddels is daar een heel veelzijdig bedriff uit ontstaan. Naast het bijhouden van minn blog, doe ik receptontwikkeling, productontwikkeling en
Professionals met een T-profiel zijn gewild. Zij geven makkelijk vorm aan vernieuwing in hun organisatie, omdat zij vraagstukken niet alleen van het eigen referentiekader bekijken, maar ook door de bril van andere disciplines. Dat leidt sneller tot beter resultaat. Als starter bouw je aan jouw T-profiel door naast specialistische kennis ook andere, relevante skills te ontwikkelen. Voor de hand liggen onderwerpen zoals big data-analyse,
Auteur Marly van Brag

praktische handvatten aangeven om veel meer te gaan ontdekken en een dagje minder vlees normaal te maken. We hebben alleri acties nam om mee te doen. Zoals een gratis Week Zonder om mee te doen. Zoals een gratis Week $Z 0$ - Vles-magazine met recepten, interviews Vlees-magazine met recepten, interviews, groenteweetjes en alle benodigde informatie over de week. Ook maakten we een presentatie vo docenten hun leerlingen in een uur veel kunnen leren over gezonde voeding, plantardig eten en celetie tussen vie esconsumptie, dierenwelzij en het milieu."

De impact van een week geen vlees En met resultaat. Boerdam: "De eerste National Week Zonder Vlees vond plaats van 5 tot en met 11 maart. Het lukte me om 53 partners enthousismeren om de campagne te ondersteunen, wamonder negon supe te ondersternon, Wa Echt mooie na wa Garden Gourmet en Philips. Daarnaast kregen we ook support van BN-ers en topsporters zoals Ed Bosch, Peter Lute en Jort Kelder. Ook koppelden we De Vegetarische Restaurantweek aan de week om te laten zien dat vegetarisch eten ook buiten creatieve marketing en gedragspsychologie. Maar denk ook aan organisatiewetenschap, automatis ring of zelfs aan artificial intelligence.

Professionele ontwikkeling gaat dus verder dan een multidisciplinaire oriëntatie, waarbij je jezelf continu uitdaagt om nieuwe vaardigheden te leren en andere disciplines te verkennen. Specialiseren alleen je eigen vak bijhouden. Het vraagt om

op een generalistische basis dus, als je het mij vraagt. Het maakt je als starter een aantrekkelijke gesprekspartner voor je collega's. Je bent immers beter in staat om samen te werken. En zo voorkom je bovendien dat je een one trick pony wordt.

de deur een feestje is. Daarnaast verkochten bedrijven, universiteiten en pompstations een groter vegetarisch annbod in hun kantines en deli's. Maar het is de impact die telt. Wanneer ie als volwassene één week geen vlees eet, bespaar je: zeven maanden douchewater, 111 kilometer auto rijden, een blije kip en zeven maanden werk voor een boom. In totaal hebben meer dan 20.000 mensen meegedaan aan de Nationale Week Zonder Vlees. Tel uit de winst voor het milieu. Maar het gaat natuurlijk om het totaalpakket; over beter voor jezelf en anderen, je omgeving en het milieu zorgen."

\section{Drie gouden tips van Boerdam}

- Zorg voor een professionele basis: een goede grafisch ontwerper is goud. Je herkent de Nationale Week Zonder Vlees van een kilometer afstand. De website zag er vanaf het begin goed uit, social media was al maanden van te voren actief en ik had een professionele brochure om mijn idee uit te leggen waarop ik mijn plan visualiseerde.

Gebruik deze vier cruciale ingrediënten voor je PR-campagne: een verhaal met een urgent onderwerp dat raakt aan de wereld om ons heen, meetbare impact die tot de verbeelding spreekt, een boodschap die ondersteund wordt door belangrijke partijen met aanzien en, waar mogelijk, een niet-commerciële afzender.

De aanhouder wint en een beetje bluffen helpt: Het was niet gemakkelijk om zoveel partners bij elkaar te krijgen, maar ik heb vertrouwd op minn boodschap en ben aanhoudend geweest in het vragen van een reactie. Dasmast heb ik vanaf het begin gedaan alsof het sowieso ging gebeuren.

YL University

Young Logeion laat Young Professionals aan het woord die jou graag iets willen meegeven over hun werk, succes of onderzoek. Innovatieve toepassingen, nieuwe technologieën en een andere kijk op het vak. Laat je inspireren door de nieuwe generatia 


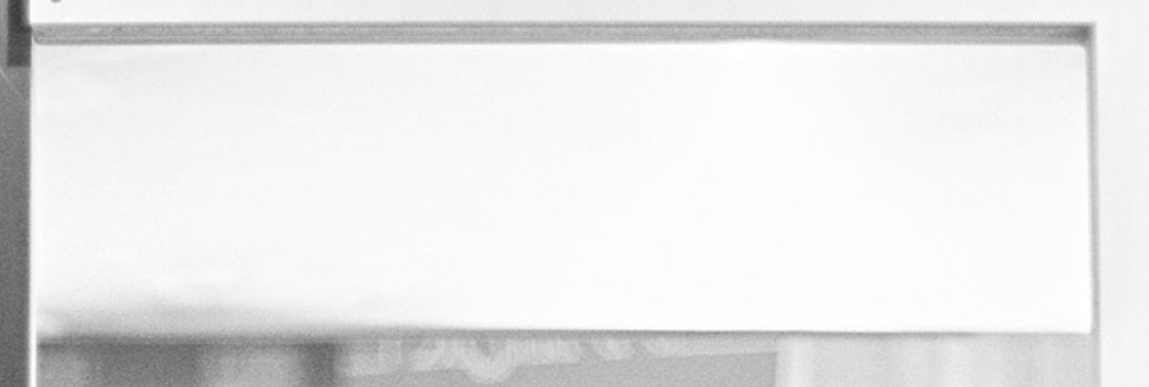

vertelt een foto altijd de waarheid?
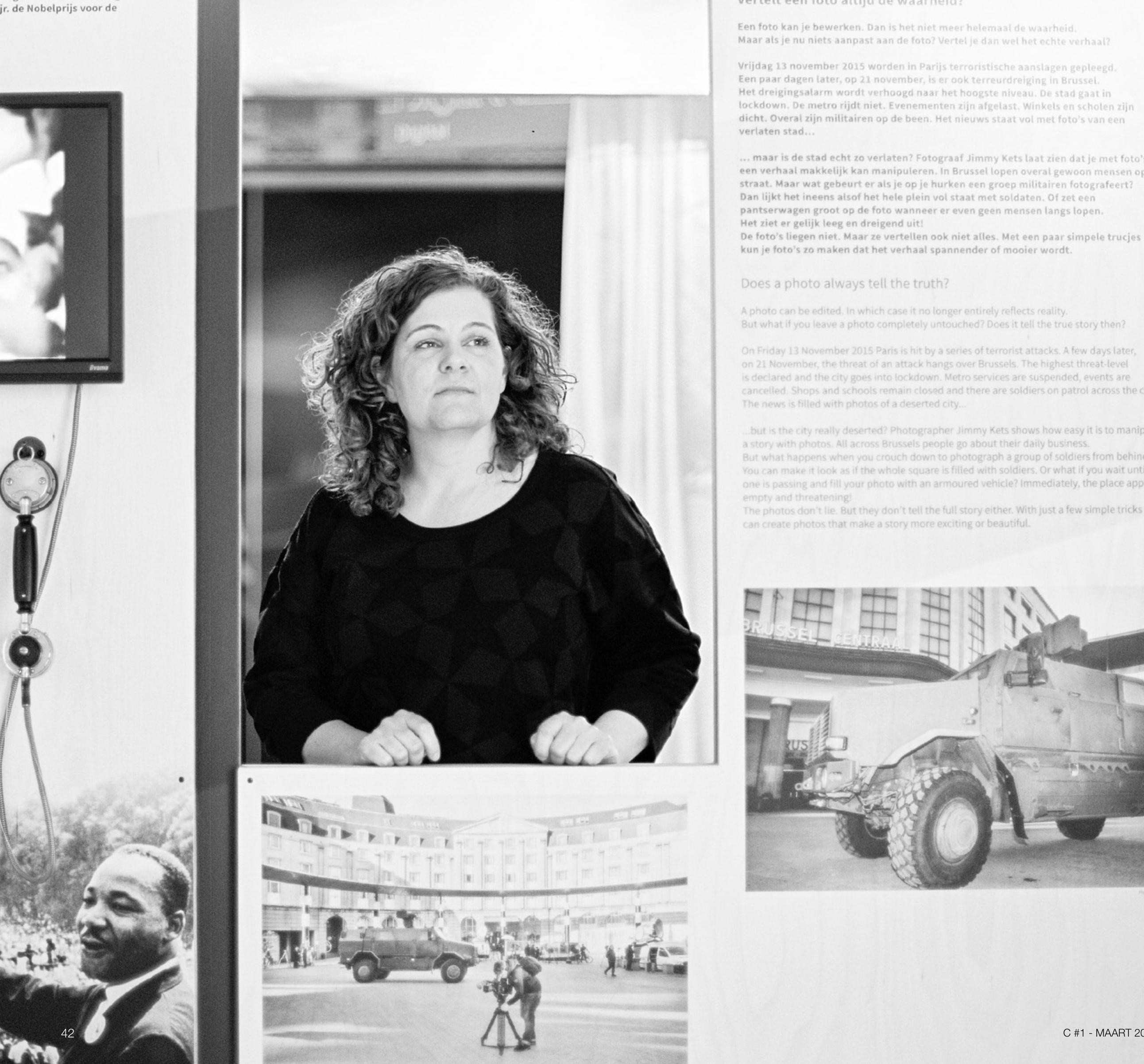

nen: 1
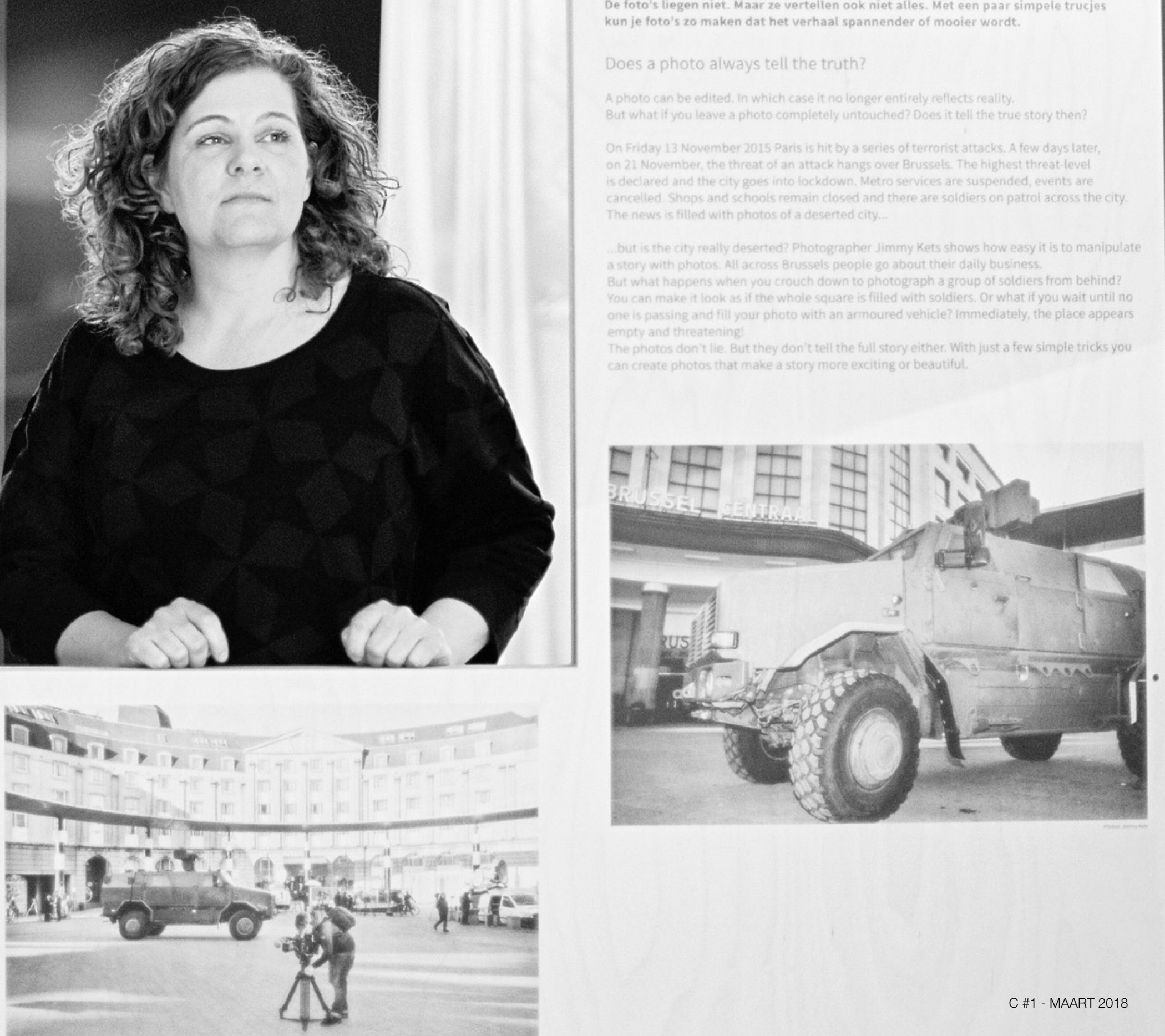

Birgit Verwer - Marketing \& Communicatie, programmering сомМ (voorheen Museum voor Communicatie)

Ervaar de impact van communicatie

De impact van communicatie kun je bij ons

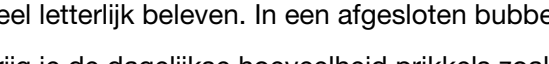
Jespres zoals gesprekken, ser bushokjes, anply gen in winkels in ben keer over je vitgestort. In die bubbel ervaar je de enorme hoeveetheid communicatie die elke dag op ons allemaal afkomt. Wanneer al die prikkels wegvallen, voel je wat de kracht van stitte is. Ook dat is communicatie en heeft impact.

Ooit zin we begonnen als een museum met een historische collectie post, filatelie, telefonie en telegrafie. Die collectie wordt nog steeds gepresenteerd op de tentoonstellingsvloeren als een nog belangrijker onderdeel dan voorheen. Daarmee vertellen we het verhaal over de impac van communicatie. Verdeeld over vier vloeren gaan we in op zaken als interactie, digitale communicatie, revolutie en actuele thema's. Dat laatste doen we met onze debatten en lezingen over bijvoorbeeld sociale media of het dark web via COMM Live. Met onze kennispartners zorgen we zo voor kennisdeling en creëren we een plek waar we het samen hebben over de maatschappelijke rol en de toekomst van communicatie.

COMM is sinds de heropening in november 2017 nadrukkelijk meer dan een museum. We stellen continu vragen om mensen bewust te maken. Wat betekent communicatie voor jou? Juist in de interactie ervaar je spelenderwiis wat communicatie is. Ook organiseren we evenementen en workshops, kun je bij ons ruimtes of werkplekken huren of gewoon een kop koffie komen drinken. En dat allemaal net om de hoek van het werkpaleis van onze koning." 


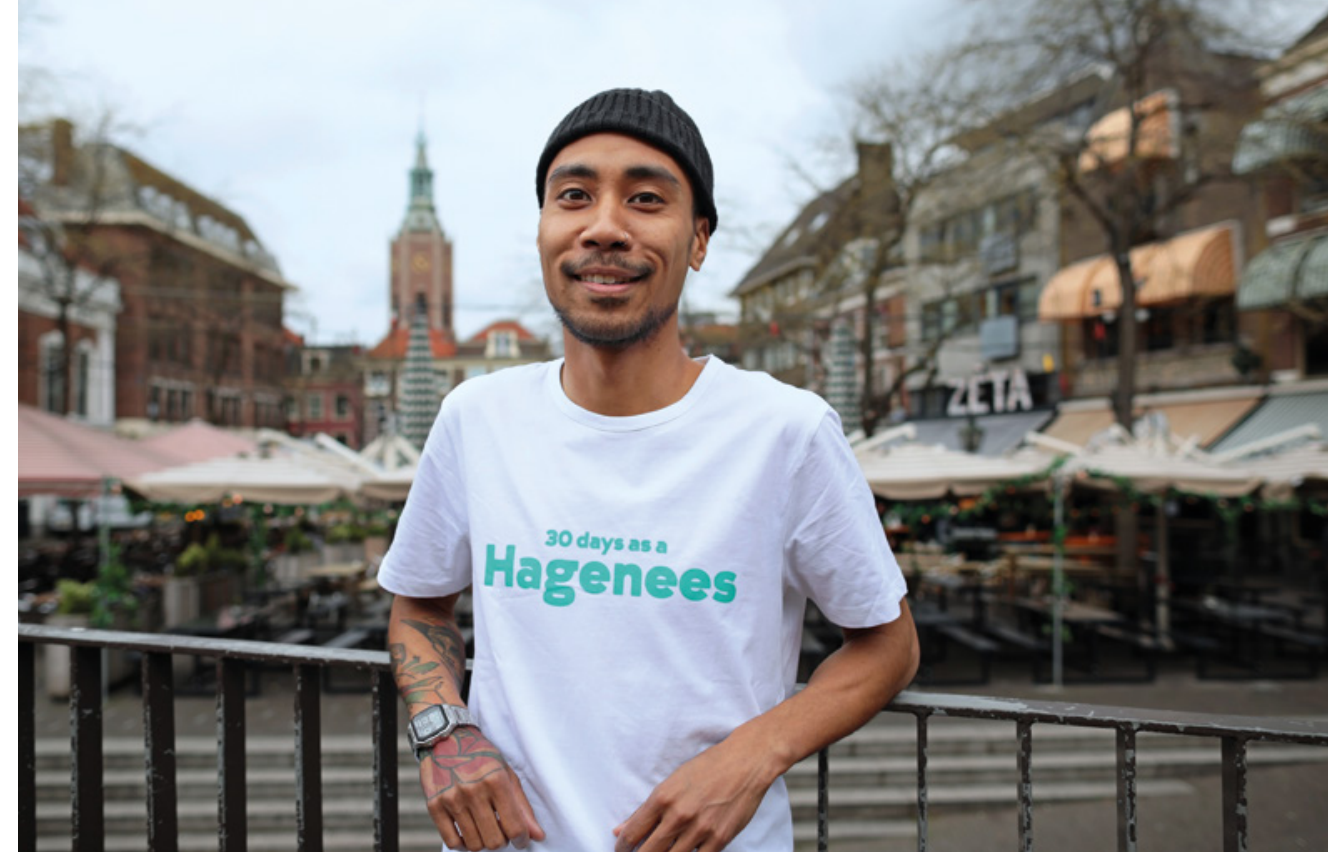

Auteur Remco Faasen

Fotograst Murice Haak en Richard Mulder (stadion)

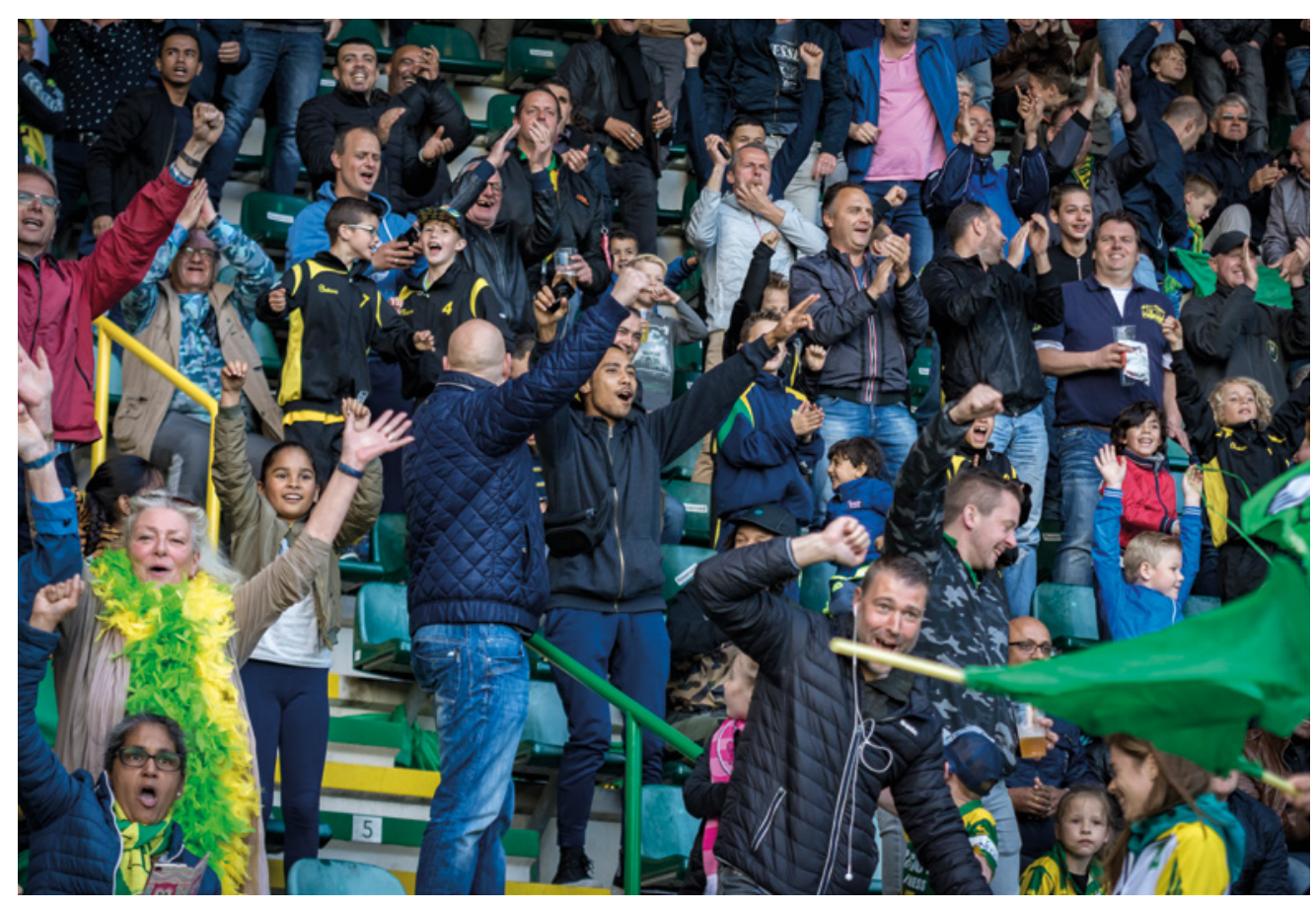

Drie young professionals Dertig dagen

Eén stad

"Oh oh Den Haag, ik zou met niemand willen ruilen, meteen gaan huilen, als ik geen Hagenees zo zijn", zingt Harrie Jekkers in het officieuze volkslied van die stad achter de duinen. De gemeente Den Haag gaf vorig jaar in het kader van citybranding drie young professionals de kans dertig dagen een Hagenees te zijn in de campagne 30 Days as a Hagenees.

Citybranding. Een must voor iedere zichzel respecterende stad. En zo ook voor de Hofstad. Den Haag heft datoor de 2020 e (a) zich wil profileren en hoe ze zich wil ontwikkelen. "In de gemeenteraad is besloten dat we ons gaan richten op jong talent," licht Luuk Helleman namens het Bureau Citybranding van de gemeente Den Haag toe. "We willen bedriven en organis creären, mar zi ko is. En dat jong talent komt alleen als er voldoende werkgelegenheid is. Een beetje het kip-en-ei-verhaal, zeg maar."

streven we ernaar ze te houden. Maar dan moeten we er wel voor zorgen dat de stad interessant genoeg voor ze is. En dan niet alleen op het gebied van carrièrekansen, maar ook om in te leven. Er venten . maar dat is maar een deel van het verhaal. Den Haag is ook een stad voor jonge ondernemers op allerlei gebieden, zeker op maatschappelijke n willen we écht onderscheidend zin. Den Haag zet zich als stad in om de wereld beter te maken."

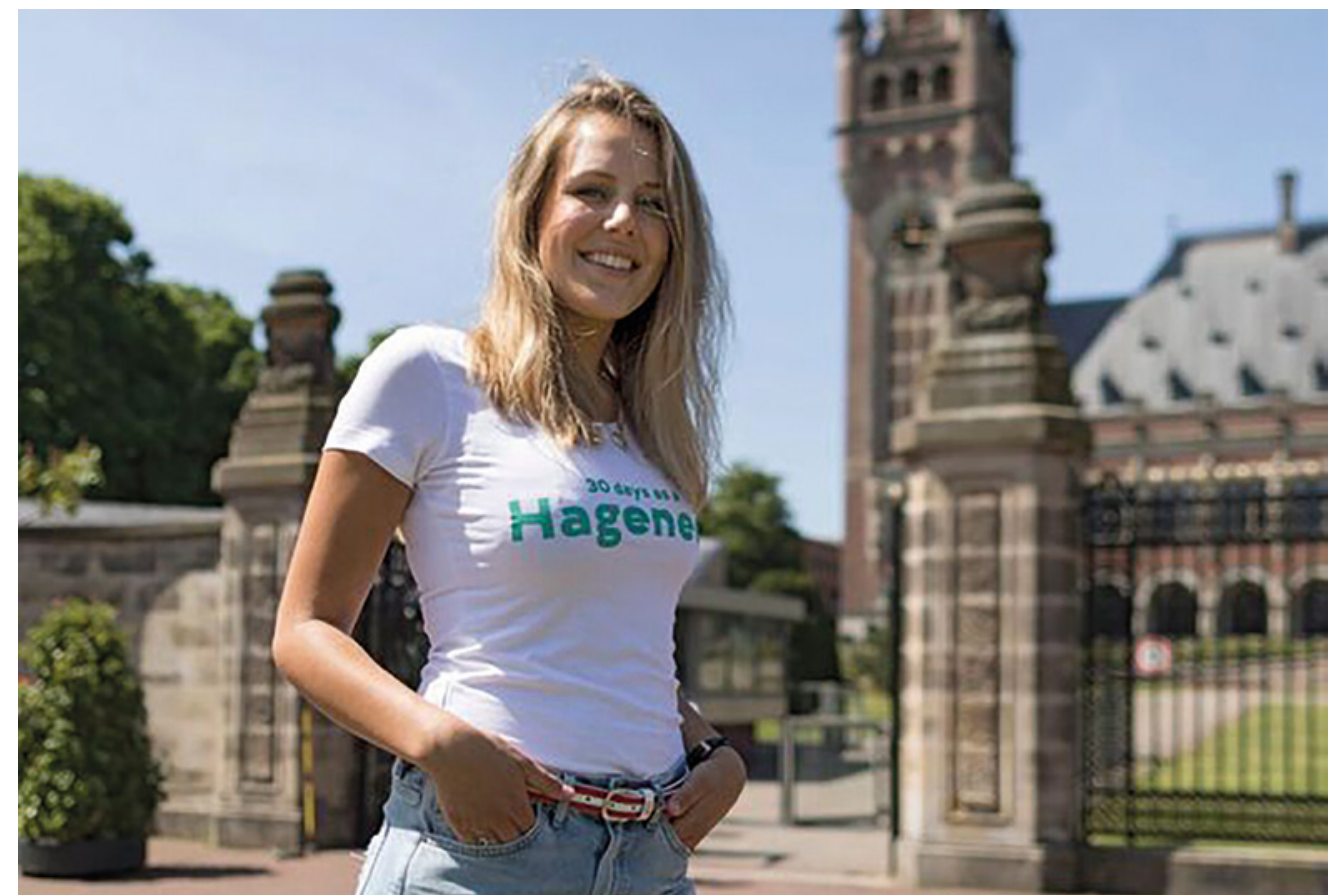

30 days as a Hagenees

Anders dan alleen maar de boodschap uit te Studenten

dragen, besloot Bureau Citybranding vorig jaar

Den Haag heeft besloten zich te richten op het binnenhalen van studenten. Helleman: "Het

anbod an opled

jaren erg gegroeid. Vooral ten aanzien van de

drie jongen de gelegenteid te geven die bood die schap zerte he

sectoren waar wij als stad op inzetten: vrede

velos

recht, veiligheid en startups met maatschappelijke

impact. Als studenten klaar zijn met hun studie,

Citybranding en voordat ik hier begon hadden w

het project Proefwonen. Daarbij konden een ? 
aantal forenzen ervaren hoe het is om in Den Haag te wonen. Maar nu wilden we veel verder gaan en young professionals écht laten voelen hoe het is om in de stad te leven. Ze hier hun huis, baan en sociale omgeving laten hebben. Dat lukt natuurlij niet in een paar dagen, daar is een langere periode voor nodig. We ziin het gesprek aangega met ons netwerk aan bedrijven, organisaties en verenigingen om iemand dertig dagen lang een Hagenees te laten zijn.

Video

Er werd een campagne bedacht, die werd afgetrapt met een groot publicitititsmoment. "We getrapt he met en knipoog lem and plekken van de stad laten zien. Aan het einde richt hij zich tot de kijker met de vraag hoe die het zou vinden om Den Haag te ervaren. Die video ging viral, met 4,8 miljoen kijkers in binnen- en buitenland hebben we een enorm bereik gehaald en er veel free publicity mee gescoord. Doordat

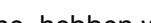
hand kunnen houden. We scoorden trouwens als bonus ook goed in de traditionele media. Al in de lanceringsfase lag de mediawaarde hier op 300.000 euro en hadden we de projectkosten eruit. Blijkbaar sprak de boodschap om dertig dagen een Hagenees te kunnen zijn aan, we kwamen nie voor niets ook in Jinek terecht met onze campagne", aldus Helleman.

Reacties

Buiten het bereik leverde de video ook nog eens 450 reacties uit binnen- en buitenland op: allem potentiële tijdelijke Hagenezen. "Er kwamen allerlei soorten reacties op binnen, van brieven en filmpjes tot complete boekwerken", blikt Helleman terug. "Wii hebben vooral gekeken naar jongvolwassenen die actief zijn op social media en daarin authentiek overkomen. Verder zou de gemeente natuurlijk het een en ander faciliteren, maar voor de sollicitanten stond geen gespreid bedje klaar. Daar moesten de deelnemers ook mee overweg kunnen. We hebben een shortliss opgesteld, gesprekken gevoerd en viteindelijk Zil er drie kandidaten overgebleven die aan alle eisen voldeden én ook daadwerkelijk dertig dagen in de stad zouden zijn. We wilden wel dat hun focus en aandacht volledig op Den Haag zou liggen." Met elukkigen kon de gemeente het compleverhaal van Den Haag vertellen. Zo was er de creatieve Hagenees (DJ/producer Vincent-Paolo Corputty), de ondernemende Hagenees (creatiev ondernemer Bas Deelman) en de maatschappelij betrokken Hagenees (Lianne de Bie, afgestudeer in watermanagement). "Zij mochten in dertig dagen proberen een goed beeld van de moge din we verin verbif, con fiets en een kleine vergoeding om $v$ e leven. Het werk dat ze deden heeft ervaring voor ze opgeleverd.

Activiteiten

De tijdelijke Hagenezen verbleven tussen mei en uni vorig jaar in de stad. "Ze wisselden elkaar mooi af tijdens hun verblijf, waardoor het voor ons beter te organiseren was en elke deelnemer goed de aandacht kon pakken. Het was fantastisch om te zien hoe behulpzaam iedereen in de stad was. Zo bood projectontwikkelaar Stebru huisvesting aan in een nieuw opgeleverd project voor studenten en young professionals bij Hollands Spoor. hielpen Haagse ondernemers met werkplekke en waren er talloze Hagenaren die de deelnem wegwiis makten in de stad of zils neter zee in voor een surfsessie. Voor de rest hebben de deelnemers hun eigen tijd ingedeeld en deden ze van alles verslag op hun eigen social media-kanaen. Uiteraard volgden wii ze met onze kanalen op de voet."

Driekwart jaar later constateert Luuk Helleman da de campagne een groot succes was. "Niet alleen kunnen we terugkijken op een groot bereik, maar we hebben met de campagne ook de internationale City Nation Place Award gewonnen. Natuurlijk waren er ook dingen die beter hadden gekund.
Onze focus lag erg op de aftrap van de campagne. We hadden de ambitie om de dynamiek die dat heeft opgeleverd vast te houden, maar toen de winnaars op de stoep stonden kwam die tweede fase eigenlijk te snel. We hadden te weinig tijd om goed na te denken over hoe we volledige exposure van hun aanwezigheid in de stad konden $k$ rigen. De winnaars vertelden hun verhaal wel, maar hun eigen netwerk bleek toch relatief beperkt. Voor het mediaplan hadden we meer tijd willen hebben, maar we waren ondertussen enorm druk met allemaal kleine, praktische zaken. Dat hebben we lopende het verblijf van de deelnemers welredelik goed kunnen maken, mar or had meer re  het project van te voren al goed uitwerken. Niet alleen rondom de lancering, met het idee dat we de rest later kunnen oppakken.

Strategie

Helleman verwacht dat het in de toekomst makkelijker zal gaan bij dergelijke campagnes die zo sterk social mer sterk social meda ged 2017 begonnen met een socialmediastrategie gericht op jong talent met bijbehorende kanalen (@BeHague en @studyinthehague) en een professioneel Haags bureau (Digital Captains) dat alles beheert, samen met Haagse ambassadeurs content ontwikkelt en de advertising voor zijn rekening neemt Nu hebr campagnes kunnen laten landen. Misschien kwam 30 days as a Hagenees in dat opzicht wel wat te vroeg. Aan de andere kant was het juist een stimulans om nu echt de social media voor jong talent voortvarend op te pakken. Tegenwoordig kunnen we onze ambassadeurs veel beter begeleiden met specifiek maatwerk en ondersteuning. De ene past meer een docula echt aan het pionieren op dat gebied in Den Haag. Den Haag is een stad die af en toe te voorzichtig was in het laten zien wat er zo mooi is. We tonen nu meer lef en durf, dat is de aanpak van onze citybranding. Onze projecten passen daarbij.

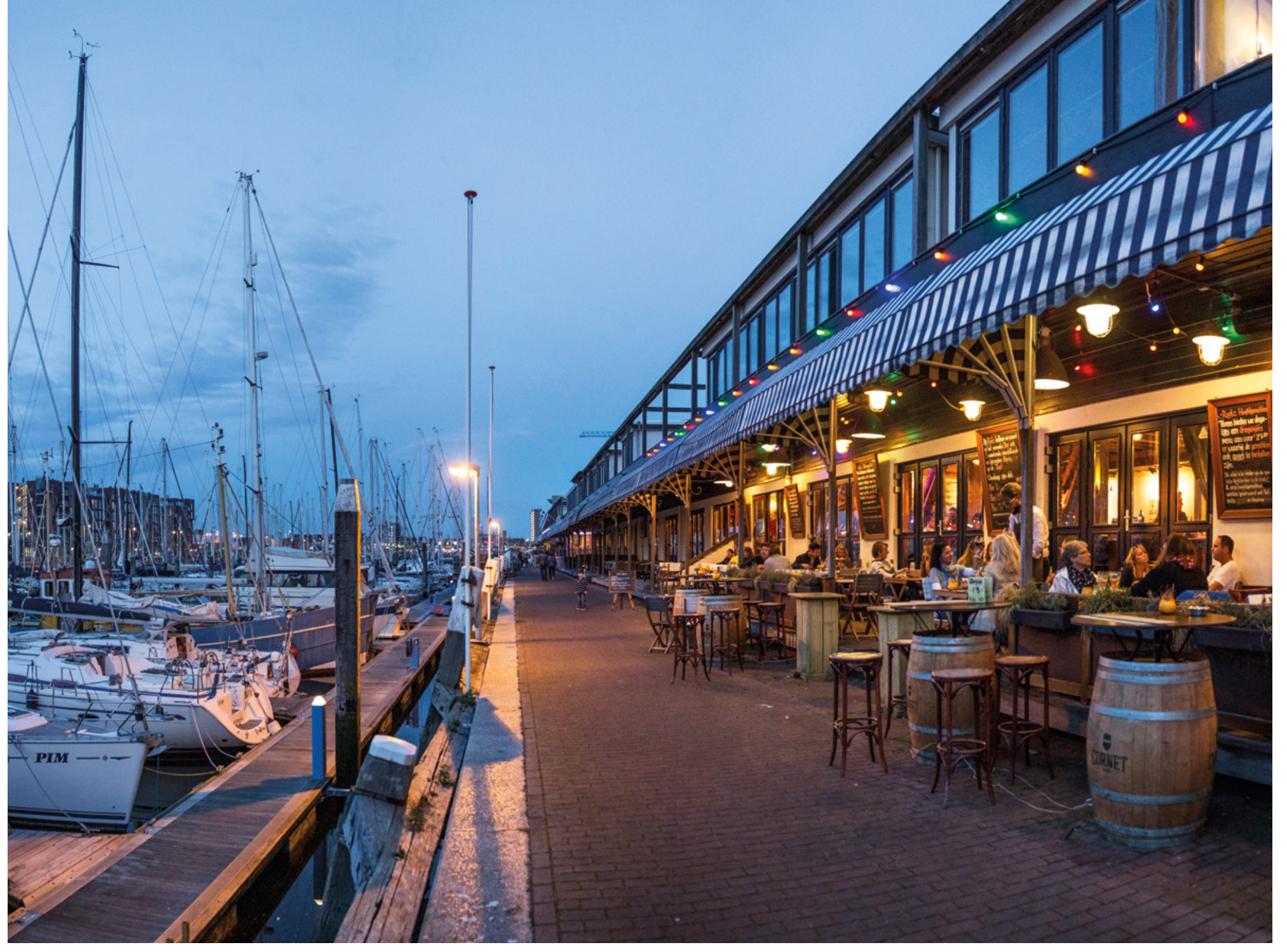

Er komt dan ook zeker een vervolg, met een piekmoment om Den Haag op de kaart te zetter. Ook dat wordt weer pionieren en ook dan zullen best weer wat zaken zin die achter best weer wat zaken gekund."

Hoogtepunten

Gelukkig zijn het vooral de hoogtepunten die bijblijven. Twee staan in het geheugen van de citybrander gegrift: "Allereerst de lancering van camper Het is mooi om te zien dat zo'n mpje het goed doet. Je probeert iets te maken dat opvalt en als dat dan slaagt is het gewoon ontzettend gaaf. Een tweede hoogtepunt was he afsluitende feest op het strand van Scheveninge Daar was iedereen bij, inclusief de deelnemers met hun nieuwe vrienden en collega's. En de mensen van marketingsuitvoeringsorganisatie
Hague Marketing Bureau. Dit was namelijk zeker niet alleen maar een gemeentelijk project. Zoveel enthousiaste mensen bij elkaar, dat was een mo halen dus? "Dit gaan we naturlikk niet simpelwe nog een keertje kopiëren, dat past niet bij Den Haag en onze aanpak waarin we steeds verfis send willen zijn. Er is een voortdurende stroom aan communicatie richting de doelgroep jong talent, met piekmomenten waarop we echt knallen. dat gaan we ook binnenkort weer doen. De insteek is daarbij dat we de publiciteit hale door Iudiek en spraakmakend te zijin."

Succes

En hoe het de tijdelijke Hagenezen is vergaan? In eder geval één is gebleven in Den Haag. Hellem lachend: "Hij heeft samen met zijn vriendin zij boeltje opgepakt en is vanuit Groningen naar Den Haag gekomen. Dat is typisch voor die doelgroep. Het zijn flexibele mensen en juist die willen we graag in de stad hebben. Ons doel is uiteindelijk om Den Haag in de mindset van de jonge talenten te krigen als een stad waar je werkt aan een betere wereld en ondertussen geniet van alle voordelen die we hebben doordat we de grootste West-Europese stad aan zee zijn. We doen elke twee jaar imago-onderzoek om te meten of we daar in slagen en we zien een stigende lijn maar we zij er nog niet. Gelukg mar vor min wat

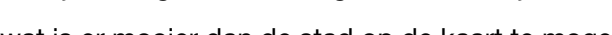
zetten waar ondertussen ook zelf je hart ligt?? •

\section{Meer informatie:}

behague.com/en/30-days-as-a-hagenees 


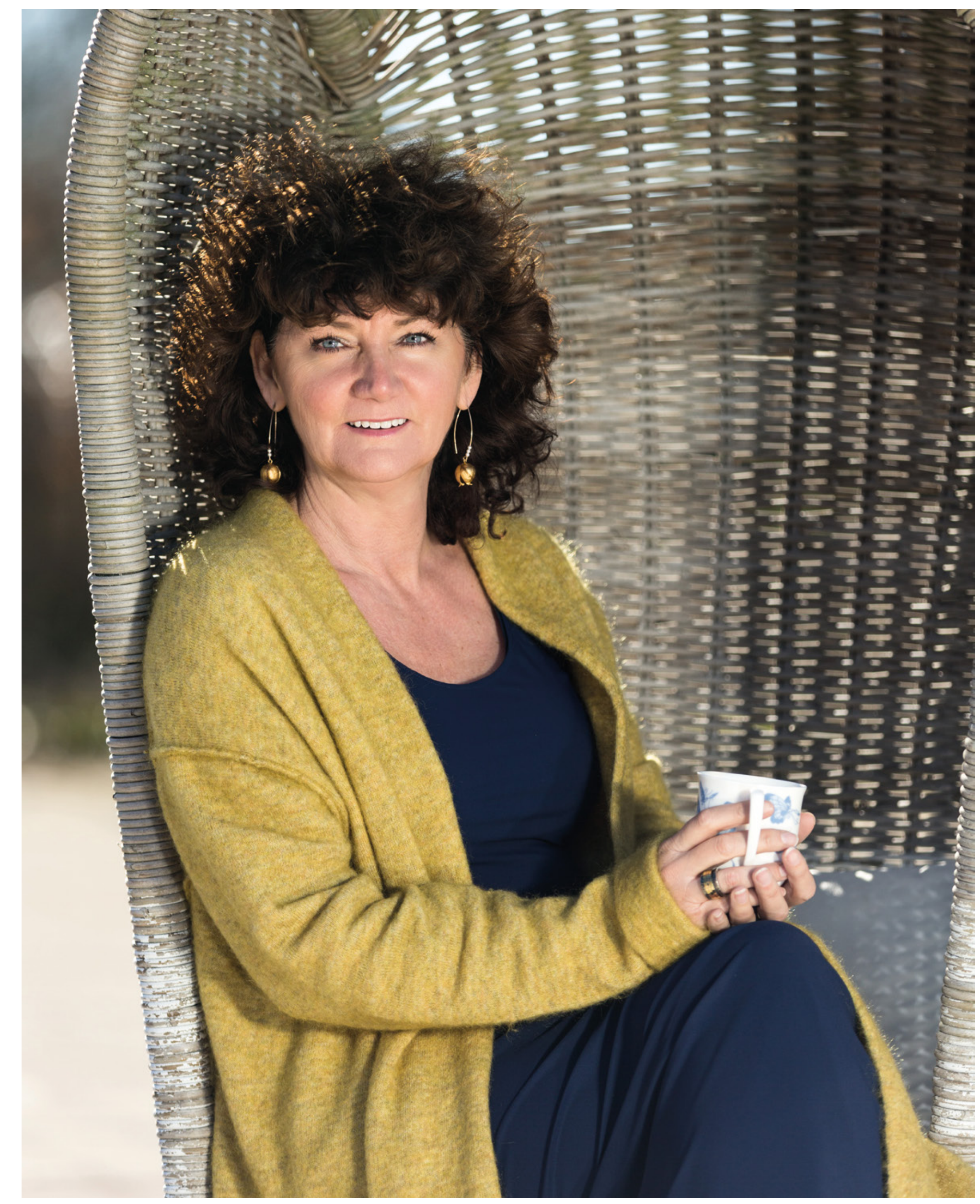

\section{Zes of negen?}

We hebben een mooi en veelzijdig vak. lk kan echter de vraag 'Waar ben je van?', niet meer horen. Ik sta ergens voor en dat niet meer horen. Ik sta ergens voor en da is het vereenvoudgen van de complexiter in communicatie tussen mensen, zodat de kans dat ze je toelaten groter wordt. Dit is gewoonweg niet makkelijk. Het start met dit te erkennen. Stop met het verkopen van loze beloftes voor onze organisaties en over onze igen impact Er is niets mis met wat moer rean meer reallethsth. Wo hebben focus nodig om $h$ vak een gezich te goven. Niet de inten centraal zetten, maar het effect. Wat ij nu voelt is het effect van mijn goede intentie. Zo simpel is het.

\section{Laat eens wat ballen vallen}

urs die ik ken willen graag tijd om te ond ger, scenario's uitdenken en anticiperen op wat er gebeurt. Waarom doen ze het dan niet? Omdat zij te veel werk hebben, opdrachtgevers vooral middelen uit de 'spullenkar' willen, vragen van de media niet mogen blijven liggen, etc. Veel communicatieprofessionals werken onzichtbaar hard mee aan van allos en nog wat. Er is goon reele tid voor onderzoek, strategle of zelis bjoblijven in he vak. Zij vinden dat zij alle ballen in de lucht moete houden. Maar moet dat echt? Is het een ramp als we eens wat ballen laten vallen? Doe al die klusjes zo efficiënt mogelijk. Een tekst plaatsen, waarvan jij weet dat niemand die leest, een middel maken dat onvoldoende gaat landen, ego-communicatio het sturen op likes etc. Jij weet dat $z$ onvoldoende impact hebben en dus kun je gaan voor een zes.

\section{Ga voor de negen}

Stel je eigen kritische succesfactoren op en weeg realistisch af of je de kans krijgt om je werk goed te doen Beoordeel of de vrang wardevolis voor het behaten van de doelen van de organisatie. he Bospreer iji de waarde inziet van jouw visie op de opdrach dan kun je voor een negen gaan. Toon nu wat communicatie kan bijdragen. Je onderbouwt je aanpak, je benoemt je verantwoordelijkheid en die van de opdrachtgever en je toetst steeds of je adves en communicatie-inspanningen het beoogde ect hebben. Je bent actief in de leefwereld van ontvanger. Je stelt bij en leert. Je reserveert tij om je opdrachtgever mee te nemen in wat je waneer en waarom doet. Je deelt je ervaringen met collega's en benoemt alle leerpunten en bevindingen die relevant zijn voor de organisatie. Het verschil tussen gevraagd worden als adviseur of te moeten vechten voor je plekje is vaak één succes.

fscheid neme

De breinvoorkeur van de communicatieadviseur is voor 95 procent gericht op de mens, toekomst, vernieuwen, mogelijkheden en ontwikkelen. Een rijkdom aan ideeën en de behoefte aan goede elaties zijn mooie kenmerken van de adviseurs. de adviseurs. Dar heidsgevoel, oon liche bewijdrang en alles goed willen doen om de hoek kijken. I z zie adviseurs die geloven dat zij de opdrachtgever moeten overtuigen door veel vragen te stellen over $\mathrm{m}$ name de communicatiedoelen, waarmee ze de opdrachtgever vermoeien. De kunst is om je te verdiepen in de belangen van de opdrachtgever. ie niet meer is dan verantwoording afleggen, wegwezen. Als de opdrachtgever echt wat wil bereiken en zich wil verdiepen in de ander, dan heb je iets in handen. Start dan met realiteitszin. Niet alleen op inhoud, maar ook in je agenda. Reserveer tijd en doe alles maal twee. Want tijdsinschatting is vaak niet de sterkste kant van de adviseur. Neem tijd om te ontdekken wat er speelt in de leefwereld van de ontvanger, want daar wordt het effect bepaald. Wees reëel en verkoop geen illusies.

Vermeniguuldigen

Als je samen met je team gaat voor een aanpak van negens en zessen, op basis van kritische succesfactoren, kun je ook samen leren van wat wel en niet werkt. Je kunt elkaar steunen bij de

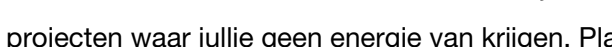
gewoon een post-it op je scherm met een negen of een zes. Kijk wat je voor elkaar op welk moment kunt betekenen. Zie je een collega een hele ochtend werken aan een zes? Hou een koffiebreak. Verzamel aan het einde van de dag alle negens en vertel elkaar kort wat je hebt ontdekt. Inspireer elkaar en voll (weer) waarom je voor het mooie communicatievak hebt gekozen. Wees vervolgens zichtbaar in de organisatie met je kennis over hoe communicatie werkt en wat er in de buiten- én binnenwereld speelt. Dan merk je vanzelf dat de negens steeds meer de overhand krijgen. En de mooiste krijg je van de ontvanger.

Dit geldt ook voor ons vakgenoten onderling Laten we eens ophouden om elkaar de maat te nemen en trots te zijn op iedereen die probeert iets bij te dragen. Dan gaan we meer experimenteren, delen en leren. Dat past ook beter bij onze breinvoorkeur. 


\section{Van planeet naar bewoners}

De evolutie van de 'IFFR' campagne

Je moet het maar durven: je filmmakers, de acteurs en je doelgroep neerzetten als een bijzondere diersoort. Toch was dat precies de insteek van de campagne van het International Filmfestival Rotterdam: 'Meet the humans of Planet IFFR'.

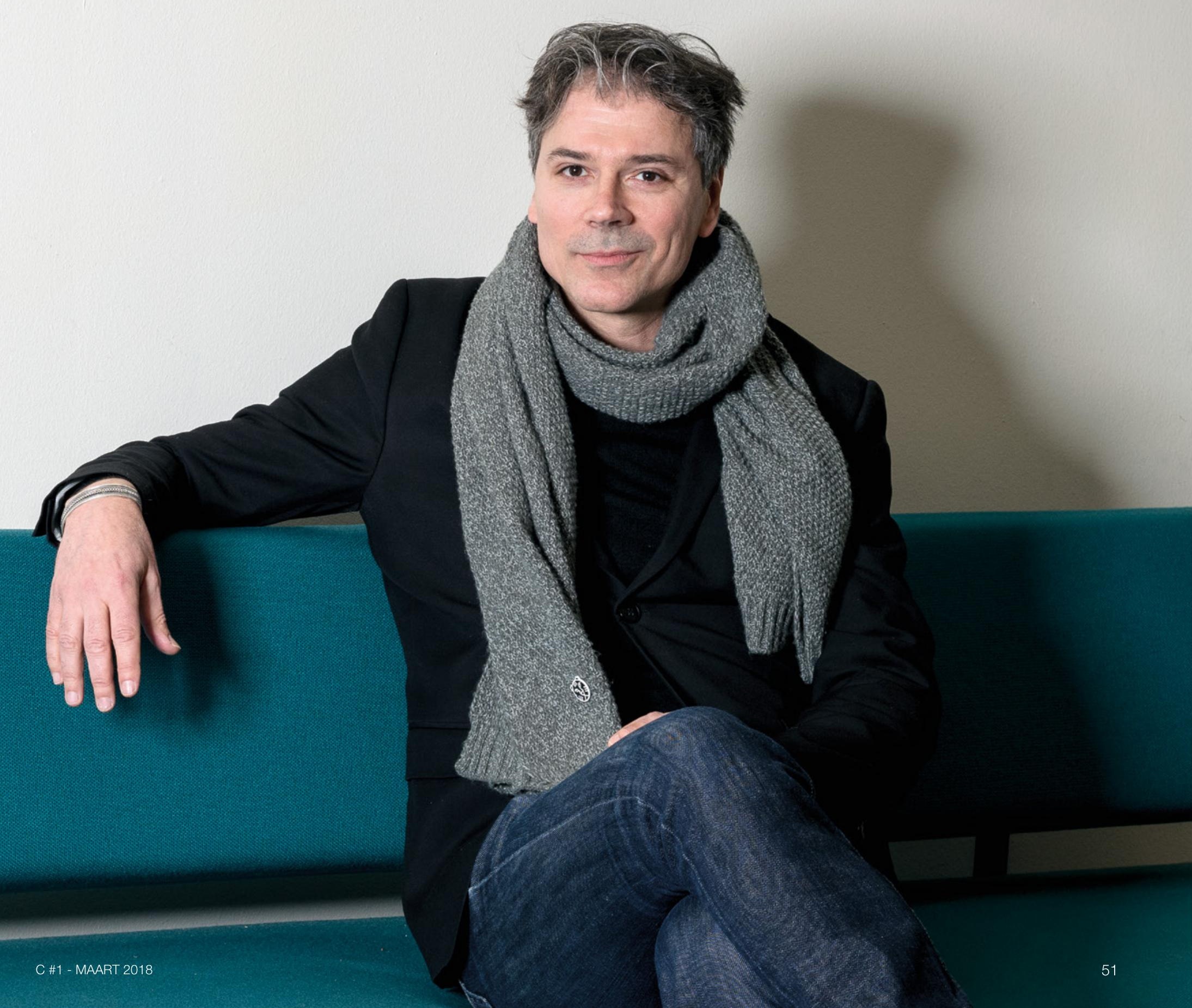




\section{Meet the humans of Planet IFFR}

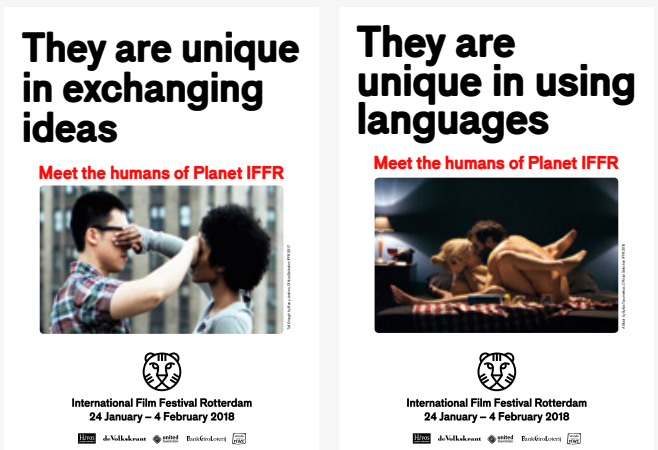

They are social

They recognise

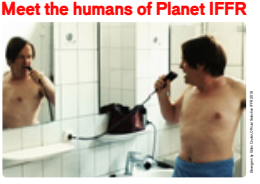

$=$

mirrors

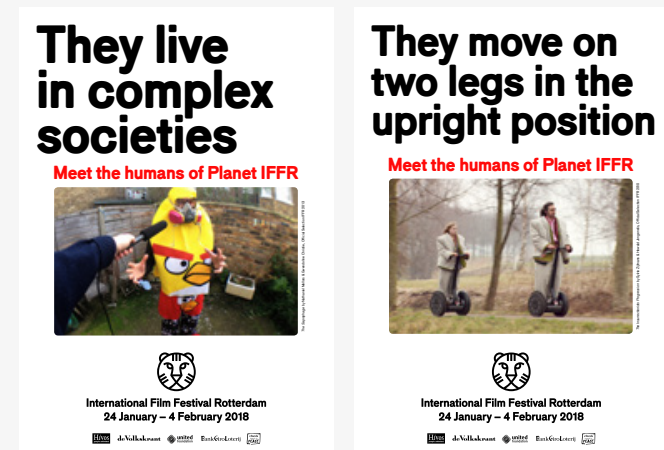

.

Op het kantoor van het International Film Festiva Rotterdam (IFFR) zijn de bijeffecten van het testival nog goed zichtbaar. Overal stan campagnematerialen. Aubéry Escande, sniffend en proestend. is zelf ook nog aan het herstellen van de drukke weken. Hij is sinds sind vorig jaar Hoofd Pers Marketing en Communicatie van het festival en mast de Cons moosi d daar nou? Escando wist op zess cozen warlop de namen van verschillende festivallocaties geschreven zijn. De dozen zitten vol met kleren, boeken en brillen. "Dat hebben festivalbezookers achtergelaten", antwoordt een van de collega's. "Echt? Bizar", zegt Escande. In een hoek staat een van de borden waar bezoekers zichzelf i i konden fotograferen als hooftrolspelers in de campagne. "Eerder deze week had een bezoeker daar zin fiets aan vastgemaakt. Hup, ketting erom en klaar. Dat vond ik een mooi, Hollands beeld in onze internationale campagne."

Kon dat wel, een beetje Darwin?

Achter de receptiebalie hangt oen van de posters Ach der uit de campagne. Een mon een Segway, op end dis ans op het platteland. Ze dragen een grijs flodderpak. Onder het filmbeeld de zin: 'They move on two legs in the upright position', gevolgd door de pay-off: 'Meet the humans of Planet IFFR'. Het is een van de slogans uit de laatste campagne van het Internat- onal Film Festival Rotterdam. De campagne is een dels 47 jaar. De $50^{\circ}$ editie is over drie jaar. Die zal nieuw hoofdstuk in een verhaal dat in 2017 begon groots gevierd worden. We zijn nu al bezig met de met de campagne 'Welcome to Planet IFFR', Of zoals het festival zelf zegt: 'Het zijn allemaal eigenschappen van de wonderlike soort die de plek bewoont die we vorig jaar al verkenden: de humans of Planet IFFP.

"Darwiniaans, zo kun je de campagne wel noemen", zegt Escande. Hij was er eerst niet helemaal gerust op. "Was het niet te intellectueel, te highbrow? Dat imago hebben we toch al een beetje en daar willen we juist vanaf." Maar de campagne vie goed bij het publiek, dat zelf aan de slag ging met allerlei variaties op de zinneties. Die het overigen $T$-shirts en allerlei andere doet al jaren de campagnes en huisstijl voor het filmfestival, inclusief het bekende Tiger-logo. Escande en zijn team vertaalden het concept Jizondere van de campagne is dat de content

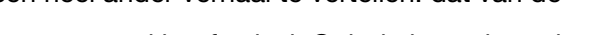
al. Ook de bezoekers dus, die zo onderdeel werden van de campagne. Hoe de verhaallijn verder wordt uitgezet, weet Escande nog niet precies. Eerst maar eens evalueren en dan vooruitkijken: "Het filmfestival bestaat inmid-

Het International Film Festival Rotterdam Het Rotterdamse filmfestival hoort bij de re grote filmfiestivals in Europa en wordt altijd de nadruk bij filmfestivals als Cannes en Berlijn meer ligt op de sterren, is Rotterdam een festival waar publiek, filmindustrie en filmmakers elkaar ontmoeten. Er is veel aandacht voor nieuw talent uit de hele wereld. Het festival bestaat inmiddels 47 jaar rek in 2018 een recordantat van 329000 bezoekers.

IFFR lanceerde dit jaar het plattorm IFFR unleashed' waar je het hele jaar door de films van het IFFR kunt bekijken. Ook, en misschien wel vooral, die films die nooit in de bioscoop te zien zin De filmma ing bion kers staan centaal, naast de flims zijn er masterclasses en interviews en wie een abonnement neemt, steunt onathankelijke filmmakers.

www.iffr.com

www.iffrunleashed.com
Uureau $75 \mathrm{~B}$ bedacht de campagne. Dit bureau van $75 B$ naar uitingen op basis van films. Het

Auteur Sanne Steensma

Allustratio Annemarie Kleywegt

Next level bereikbaarheidscommunicatie in Rotterdam eind jantuar/ begin februari gehouden. Wa
In juli 2017 is de Rotterdamse Maastunnel afgesloten in zuidelijke richting. Deze afsluiting duurt in total twee jaar. In die periode word te tunnel flink teerear. In die periode word was de Maastunnel Rotterdams drukste oeververbinding. Dus als die in één keer voo de helft dicht gaat, heeft dat gevolgen Veel mensen moeste manier van werken. Om dit in goede banen eiden, werd in de zomer van 2017 het online bereikbaarheidsplattorm Rotterdam Onderweg (www.rotterdamonderweg.nl) gelanceerd.

Pascal Hofmann, Communicatiemanager Bereikbaarheid \& Mobiliteit bii de gemeente Rotterdam: "Op onze website kan iedereen realtime bekijken of het verkeer doorrijdt of niet. En daar dus zijn route, vervoermiddel of vertrektijd op aanpassen. Het camerabeeld is een toegevoegde waarde op bijvoorbeeld Google Maps. Het verkeer echt stit zien staan spreekt toch meer dan een rood lintie op een kaart. Ook zijn de camerabeelden handig voor ons webcare-team, die reizigers op voorhand kunnen adviseren en andere route of alternatief vervoer te kiezen."

\section{Samenwerking}

Op maandag 21 augustus 2017, de eerste dag na de zomervakantie, haalde Rotterdam Onderwes het NOS Journaal van acht uur. De reden? De beelden van 24 gloednieuwe verkeerscamera's gingen live. Daarmee werd de verkeerssituatie op 19 drukke wegen en kruispunten real-time in beeld gebracht. Dit gebeurde in Nederland nog nooit eerder op deze manier. Kortom, een primeur voor Rotterdam.

We hebben ons bereik ook zeker te danken aan menwerking met lokale en regionale partijen". Idus Hofmann. "Zo staan alle camera's op ebouwen van partijen die hun dak beschikba hebben gesteld aan de gemeente. Denk bijvoorbeeld aan het Erasmus MC of de Bijenkort. Dankzij hen hebben we dagelijks zicht op de verkeerssituatie op onder meer de Coolsingel, het Vasteland en de Westzeedijk."
Regionaal werkt de gemeente samen met RTV Rijnmond. Ook voor Rotterdam Onderwes. Hofmann: "Rijnmond wilde graag gebruikmaken van onze dienstverlening en wij op onze beurt van hun grote regionale bereik. Op www. Itvrinnmond.nl/verkeer is daarom een iFrame geplaatst met daarin de belangrijkste informat van Rotterdam Onderweg."

Altijd bliven ontwikkelen

Voordeel van een online plattorm is dat je kun blijven innoveren. Sinds de eerste release zijn we daar dan ook continu mee bezig. In het bijzonder met de interactieve kaart op onze homepage", zegt Hofmann. "Op die kaart zie je of er ruimte is in parkeergarages, waar de dichtstbijzijnde laadpaal is én waar je een fiets kunt huren. Het mooist vind ik de optie voor het real-time inzicht in ov. Dat zie je live rijden op de kaart. Ideaal om te weten of je je moet haasten. Als je het mij vraagt, stopt het hier niet. We willen onze impact en ons bereik blijven vergroten. Alleen op die manier zorgen we ervoor dat iedereen die in, om, van e naar Rotterdam reist, weet hoe hij er komt."

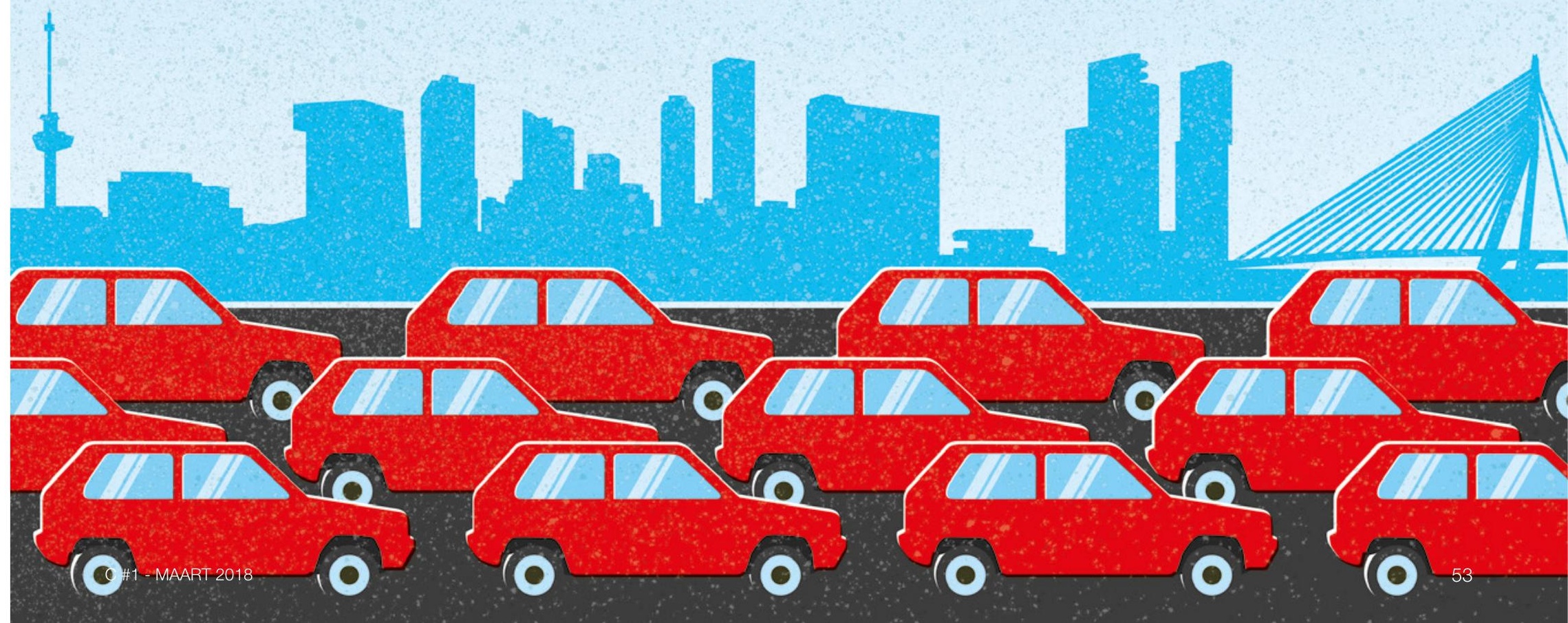




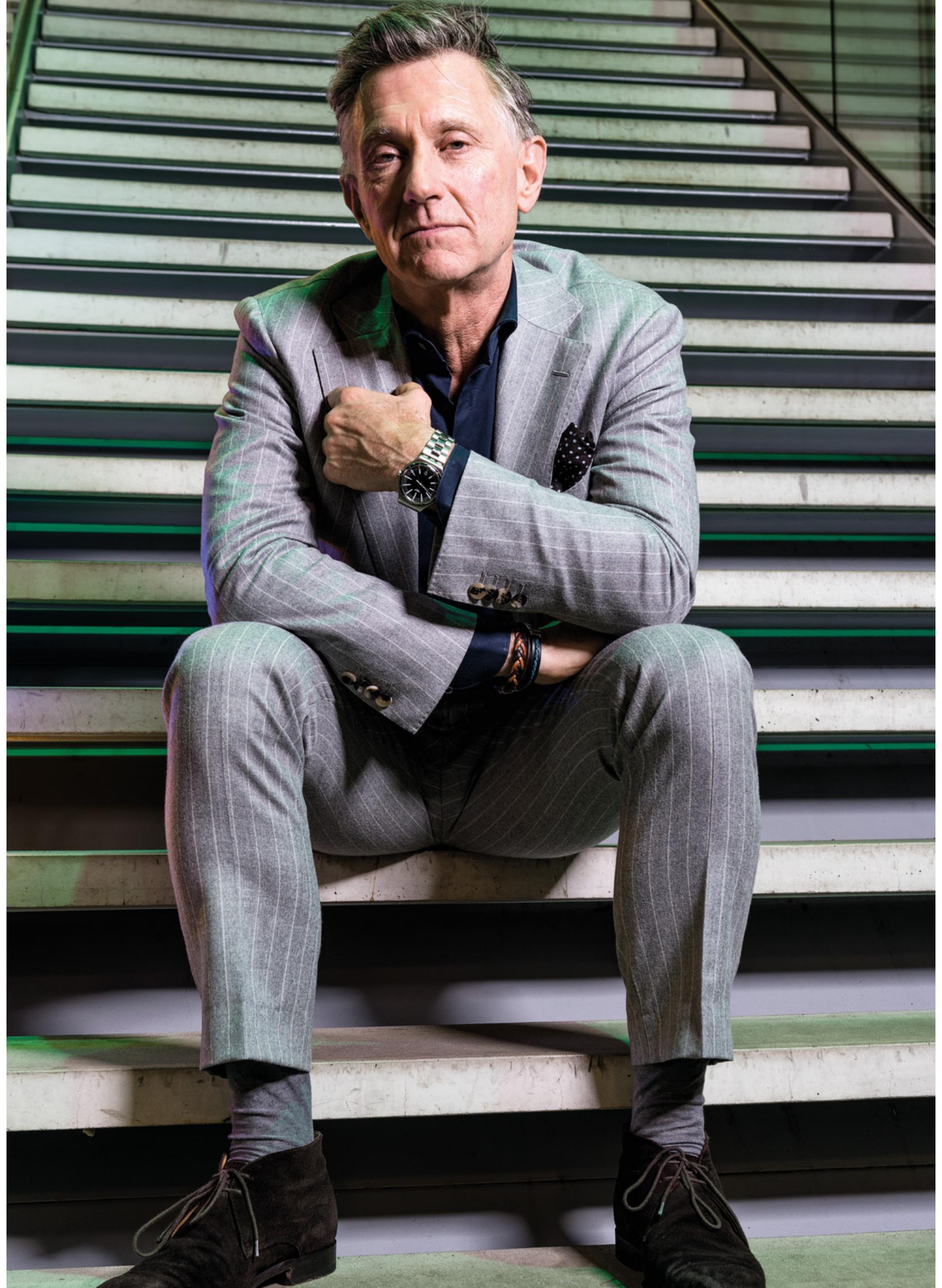

\section{Wat maakt communicatie excellent?}

Dr. Piet Verhoeven doet al ruim tien jaar onderzoek naar excellent communiceren en schreef er samen met Europese vakgenoten een boek over.

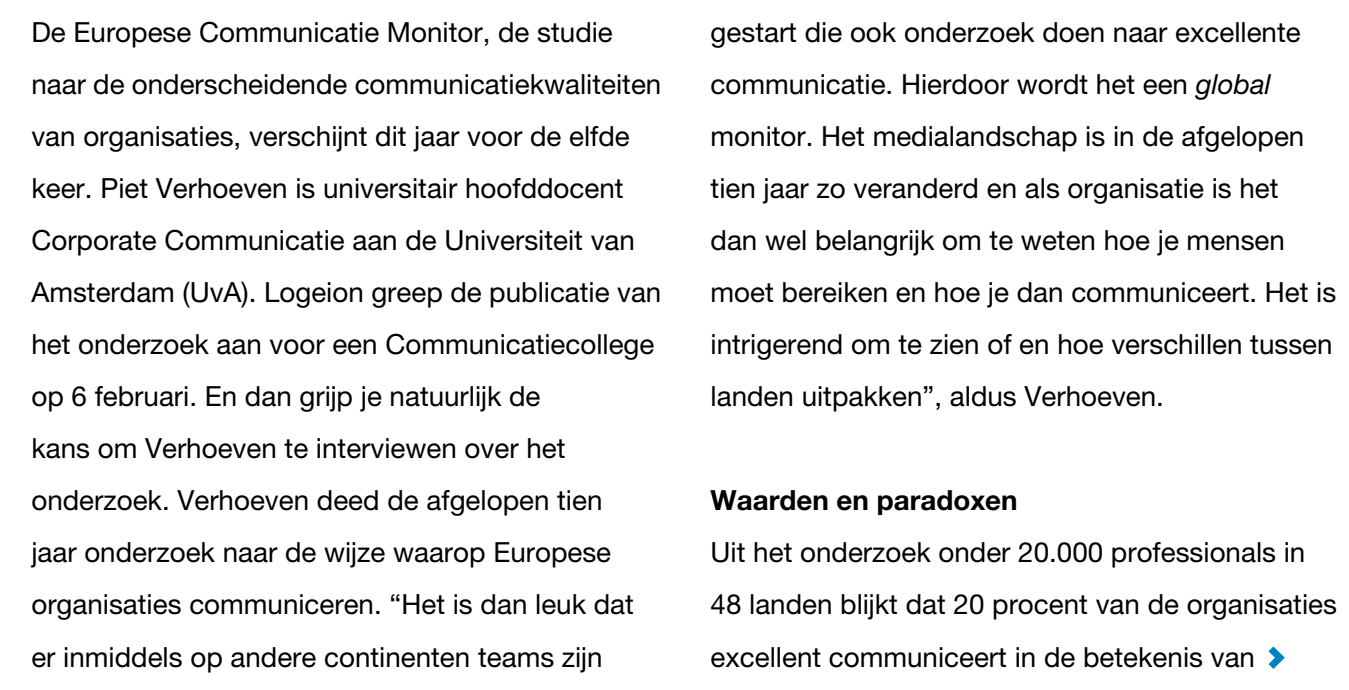


de ontdekte waarden, of 'deugden', zoals een Ielnemer aan het Communicatiecollege fijnties opmerkte. Dat betekent dat er bij 80 procent van de organisaties in ieder geval ruimte voor verbetering is. Tijdens het college sprak Verhoe over drie niveaus en de waarden, die hieraan zijn gekoppeld. "We stelden voor de definitie van wat 'excellentie' is een raamwerk op. Daar worden drie niveaus van presteren onderscheiden, namelijk: connected organisaties, invloedrijke afdelingen en de ambitieuze professional. Op elk niveau bepalen drie kenmerken hoe men to de excellente prestatie in staat is, waarbij de onderzoekers ook een aantal paradoxen hebben ontdekt. Door deze opbouw ontstaat als het ware een checklist, waarmee je kunt beoordelen waar je als afdeling of organisatie staat of dan wel op moet letten om excellent te communiceren.

'Op elk niveau

bepalen drie

kenmerken hoe men

tot de excellente

prestatie in staat is'

\section{De verbonden organisati}

"Als voorbeeld lichten we het eerste niveau met de waarden er even uit, de connected organisatie. De drie waarden zijn globalised, mediatised en reflective. Wie globalised wil zijn, presenteert zich als organisatie open minded, empathisch en gefocust, met behulp van een eigen visie en heldere doelstelling", aldus Verhoeven. Dit vraag best veel van een organisatie, want hoe acteer je in een wereld die steeds kleiner wordt, en waari we tegelijk steeds meer met elkaar zijn verbonden wereldwiid?

Mediatised staat voor een doordachte en vooral meervoudige kijk op mediagebruik. "Dit herkent denk ik iedereen wel. Onze huidige samenleving wordt gekenmerkt door een steeds grotere codiagebruik. We leven als het ware in media. Concreet houdt het in dat we op weg zinn om samenhangend te kijken naar de rol van de vrije pers, eigen media van de organisatie en de sociale media, niet alleen met het oog op slimmer zenden, maar vooral ook om in staat te zijn tot een adequate interactio."

De traditionele scheidslijnen zijn inmiddels zo goed als verdwenen. De tijd waarin we drie groepen media op een andere manier van (a)

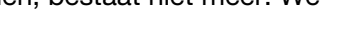
onderscheid meer in middele om te communiceren? Verhoeven: "Nee, communicatieprofessionals vinden nu alle media even belangrijk en kiezen uit meer media dan tien jaar geleden als ze een doelgroep willen bereiken. Dit vraagt echter wel om de nodige kennis en vaardigheden want het medialandschap en de werking van media is veel complexer geworden! Hoe denk je dat het bij jou op de afdeling ervoor staat? Meet je dat bijvoorbeeld wel eens?"

Reflective, de derde waarde wist op het belang om als organisatie te blijven reflecteren. Kijk je wel eens door de ogn Hoe is de relatie? En in hoeverre betrek je de stakeholders bij het nemen van beslissingen? Verhoeven onderstreept het belang van deze waarde of deugd. Het komt er op aan, dat je jeze als organisatie steeds opnieuw moet uitvinden, want de omgeving blijift veranderen en on excellent te zinn zal je dan ook continue moe aanpassen. Dit betekent dus dat je veel met e leerproces bezig bent en Aan paradoxen bij de realisatie van dit niveau geen gebrek, zo zagen de onderzoekers. Neen reflectivitit: hoe kun je rustig beschouwen en tegelik snel en effectief z zin? Een and prakijk pardox kwam op het vak mediacontacten aan het licht: de behoefte aan openheid kan op gespannen voet staan met de behoefte aan controle. Verhoeven: "Tijdens het Communicatiecollege lichtte ik toe hoe het er op aan komt deze spanningen te herkennen, te erkennen en in de organisatie op het juiste nivea

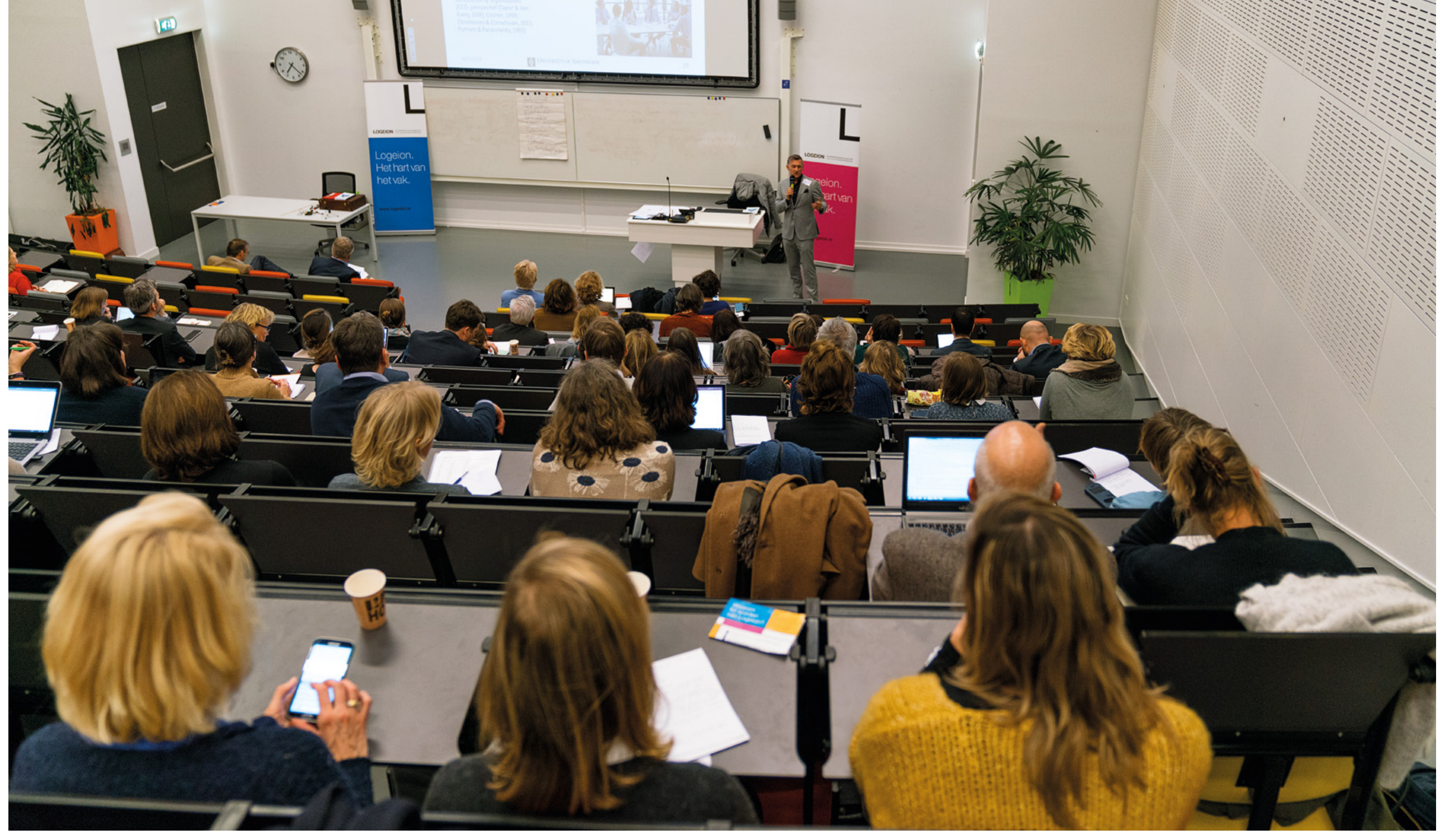

aan te kaarten. Het is zeker niet altijd makkelijk, maar zo'n checklist kan je hierbij helpen."

Theoretische basis

Wanneer we bezig zijn met verbeterplannen of doelstellingen behalen, gebruiken we vaak onbewust theorieën die ontwikkeld ziñ. En de wereld verandert zo snel, welke theorie is dan nog van toepassing vandaag de dag? "Uit ander onderzoek komt een top drie (a) arver gebrilite is de cultivatietheorie, gevolgd door erde persoonseffect en agendasetting", aldus Verhoeven. Een van de belangrijkste tips van Verhoeven is dat we meer gebruik moeten maken van wetenschappelijk onderzoek en kijk dan verder hoe je dit kan vertalen binnen je eigen organisatie. "Het heeft weinig nut om zelf het wie uit te vinden, als er al zoveel kennis beschikbaar is. Maak er dus vooral gebruik van en maak daar tijd voor. Zoek wetenschappelijke artikelen op en blifi je vooral verdippen in nieure matere en en ontwikel door op din tenslotte nooit uitgeleerd. De wereld verandert zo snel, we moeten in beweging blijven om alle ontwikkeling bij te blijven houden. Het is dan best logisch dat je als organisatie of afdeling nooit 100 procen kan scoren op alle viakken, als het gaat om excellentie. Je kunt wel kijken naar hoe je scoor en vervolgens kun je aan de hand van de checklist jezelf verbeteren."

Ten jaar onderzoek is niet niks. Wat is de meest verrassende conclusie uit het onderzoek? Verhoeven: "De meest verrassende conclusie toch wel dat je ziet dat het lastig blift om de The was dit namelijk ook al een issue."

Wie meer wil weten over de drie niveaus van excellent communiceren en de daarbij onderscheiden waarden, vindt in het boek veel handvatten om de organisatie, de communicatieafdeling en zichzelf nog excellenter voor de dag te laten komen.

Communication Excellence. How to Develop, Manage and Lead Exceptional Communications, Ralph Tench, Dejan Verčič, Ansgar Zerfass, Angelus Moreno en Piet Verhoeven, Palgrave Macmillan, 2017. $€ 42,98$ 


\section{De klassieke rol van}

de communicatie-

professional om

met een stabiele

lineaire aanpak aan

de slag te gaan,

verdwijnt naar

de achtergrond
Als je het vierluik op www.logeion.n//trends proeft, krijg je de smaak te pakken: creating shared value, always on the spot, van netwerk naar 'bubble' en verbeelden \& beleven zijn de zaken die er de komende tijd toe doen. Tegell komt de beschrijiving instrumenteel over en gericht op resultaten voor de eigen organisatie. Alsof die in het midden staat. Kenmerkend voor wat er op communicatiebordjes terechtkomt, is dat het steeds minder gaat om eenvoudige, afgebakende vraagstukken. De klassieke rol van de communicatieprofessional om met een stabie ineaire aanpak aan de slag te gaan, verdwijnt har de achtergrond: de aandacht voor scrum bijvoorbeeld getuigt daar van. Complexer situaties zoals huisvesting van kwetsbare groepen, ingrepen in woonwijken, plaatsing van windmolenparken, maken duidelijk dat het denk vanuit de organisatie alleen tekort schiet. Dat het veel meer draait on dynamische relaties teractie tussen spelers en omstandigheden. En dat een communicatieprofessional een rol kan spelen om vanuit die grillige samenhang te helpen - inspelen op de werkelijkheid. Met alle ongemak van dien.

Trendtoets

We zoomen in op de week na de aardbevingen in Groningen, al was het mar ond zover Groningn a was het an one er, bedoeld of onbedoela, gewild of ongewild bij betrokken waren en de media ons van alle kanten een inkijkje bezorgen. We zien hoe een vertegenwoordiger van de Nederlandse Aardolie Maatschappij (NAM) aankondigt dat het aantal plekken waar geboord wordt, zal worden teruggebracht áls dat van overheidswege enminste duidelijk wordt angegeven. We

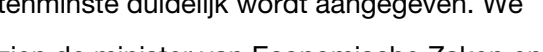
zen de minister van Economische Zaken en Kimaatbeleid op werkbezoek: het komt er nu op aan duidelijkheid voor de Groningers te verschaffen met een 'schadeprotocol'. Boze burgers beweren dat de nieuwe minister een kans verdient en tegelijk tonen ze weinig fiduce in de totstandkoming van afspraken. We zien de baas van het Staatsmijnentoezicht; hij verhaal over de lastige afweging tussen veiligheid en leveringszekerheid. Natuurlikik, de situatie ontwikkelt zich verder, we ken en netver (n)

\section{Dieperliggende waarden}

Trend 1 - 'Creating shared value' - stelt

het zoeken naar de gedeelde economische waarde centraal. Op het moment dat primaire humanitaire waarden, zoals veiligheid van wone en respectvolle bejegening, onder druk staan schiet zo'n economische blik alleen enorm tekort. Naast de rationele vraag naar de vergoeding van schade en de leveringszekerheid van het gas, bepalen de humanitaire waarden het sentiment en het discours. Veel meer gaat het om de vraag of en hoe betrokkenen eri shagen die beide perspectieven te verbinden. Hoe te handelen in deze complexe opgave: daar kom je alleen achter als je het perspectief van de inwoner én de aardgaswinner, de provincie- of stadsbestuurder én de belangenbehartiger op waarde kunt schatten. Dat gaat verder dan kijken naar de 'probleemeigenaren'. ledere betrokkene heeft een ander deel van het probleem en ook een eigen ber ijsberg van belangen, rollen, emoties en drijiveren waarbij waarden als rechtvaardigheid en veiligheid per definitie verschillend gewogen worden? Laat die verschillen toe. Gun jezelf een "leerzam wriving', in de woorden van filosoof Harry Kunneman. Daar waar het schuurt, waar waarden botsen, ligt een kans om het echte ongemak te ontdekken.

Het belang 'Always on the spot' te zijn, de tweede trend, bewist zich beslist in deze casus. Maar uit de beschriving licht het beeld van een cockpit op. Het is de valstrik van de feiten, die data-analisten al te graag voorhouden. De redenering meten $=$ weten, weten $=$ voorspellen en voorspellen $=$ beheersen past in de maakbaarheidsjaren eind vorige eeuw. Natuurlijk doen de feiten ertoe, ma Groninger casus toont ook

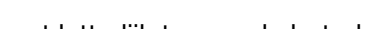
komt letrenke usen de betrkknente staan, vanuit die aansluiting aan elkaar te tonen wat je weet én wat je niet weet en kwetsbaarheid dus niet als zwakte te zien. Kwantitatief onderzoek alleen schiet daarbij vaak tekort, weten we,

kwalitatieve vormen zijn nodig om te doorgronden wat mensen beweegt en zo 'de plek der moeite'

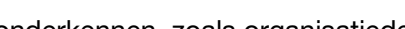
an inter-esse: er tussen zijn.

De derde trend - 'Van netwerken naar bubble' wijst indringend op de betekenis van gesprekken en 'faciliteren van dialoog'. Er zijn mensen die werkwoorden als 'verbinden' en 'luisteren' niet meer kunnen horen (vooral: 'Ik hoor wat je zegt). Bubles Bubbes Ons-kent-ons. Buc complexe opgave gat het or uist om: help partijen uit de bubble komen - van bonding naar bridging noemt Noelle Aarts da. Help zo gemeenschappelijke ruimte te creëren voor nieuwe perspectieven: wat gaan we doen? Daarin helpt de dialoog, die zoals David Bohm aangeeft, niet zozeer een tegenhanger v 'monoloog' is, maar duidt op het vermogen om elkaar en de situatie te door-zien, wederkerio contact te maken over de waarden die geraakt $z$ en tot verontwaardiging leiden. En van daaruit te kijken wat de opgave nodig heeft. Nog een stapje verder dan het samen koffie drinken: mogelijke uitzichten verkennen.

Bij 'Verbeelden en beleven', trend nummer 4 gaat het niet alleen om informatie vormgeven Beleven heeft in complexe situaties ook een andere betekenis: het komt dan aan op zeggen wat je doet en doen wat je zegt. Zoals de Belastingdienstslogan 'Leuker kunnen we het niet maken, wel makkelijker' staat of valt bij een daadwerkelijk vereenvoudigde belastingaangifte. Zo ook draait het in het Groningse voorbeeld om boter bij de vis: betroumbaar handelen. Naturrijk, daarbij kan een infographic duidelijkheid bieden, mar de echte beleving vraagt niet alleen om en beeldende of pakkende rangschikking van feiten, maar -ook- om gevoelde erkenning van het ongemak. Pas dan wordt het mogelijk een opstapje te bieden om het - nu eenmaal niet weg te denken - eigenbelang te plaatsen in de Wontert van meerdere zienswizen waaronder het algemeen belang, zoals politicologe

Deborah Stone betoogt. Dat kun je nooit vanu én organisatie, dat is altijd een kwestie van partnerships, ook al zijn die maar tijdelijk.

\section{Meervoudig denken: én-}

De praktijk leert hoe tal van organisaties uit evaringen met complexe opgaven inzichten putten om verder te kijken pur denken wenken niet alleen andere nieuwe vormen van communiceren, maar ook andere typen tijdelijk werkbare afspraken (het begrip is van André Wierdsma), ander beleid en andere uitvoering. Het meervoudig perspectief op een opgave en het aftasten wat er onder argumenten schuilgaat aan belangen en waarden is fascinerend en leerzaam. Het werpt een andere blik op hoe we met elkaar interacteren. De set Logeion-trends helpt daarbij. Vooral als we ze ook breder verstaan als een appel om communicatie kennis in te zetten bij het helpen omarmen van complexiteit, zodra partijen op elkaar aangewezen zinn en denken vanuit de opgave die de meeste meerwaarde biedt. $\bullet$
Nijmegen. In 2017 publiceerde

zij 'Halte ongemak. Waarderend communiceren maakt het verschi" gratis te downloaden vanaf www.dewaardering.com, waar je ook meer informatie vindt over de genoemde bronnen (o.a. Kunneman, Wierdsma, Arendt, Stone). 

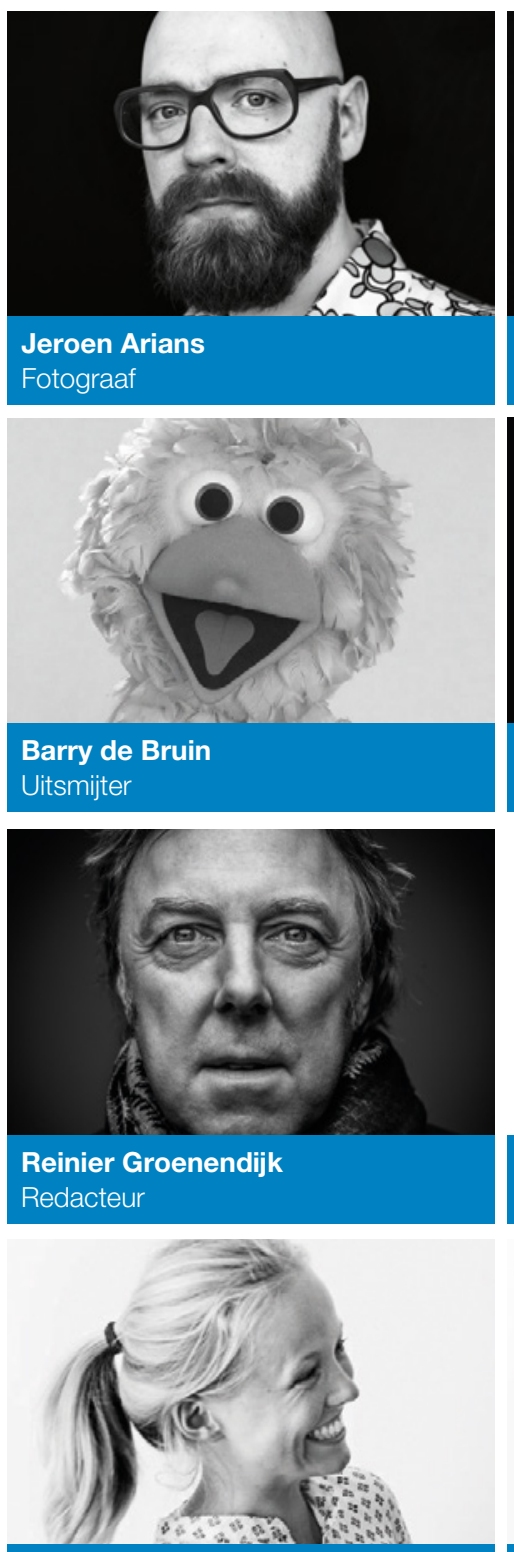

Marieke Odekerken

Fotograaf
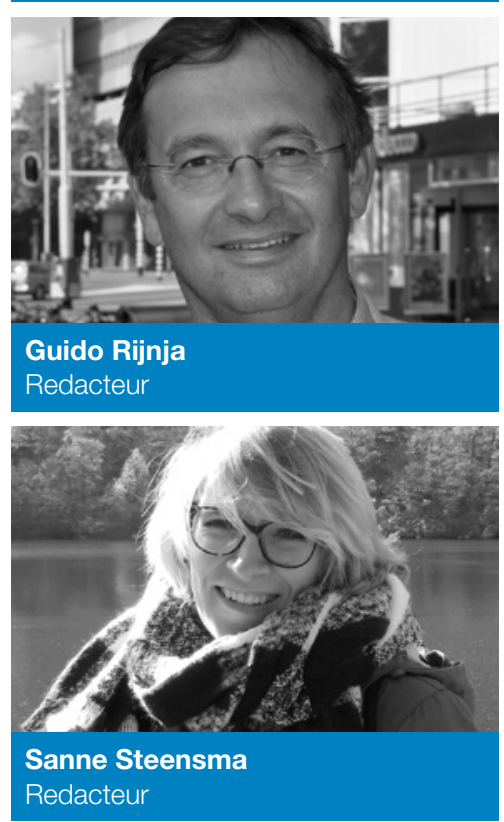
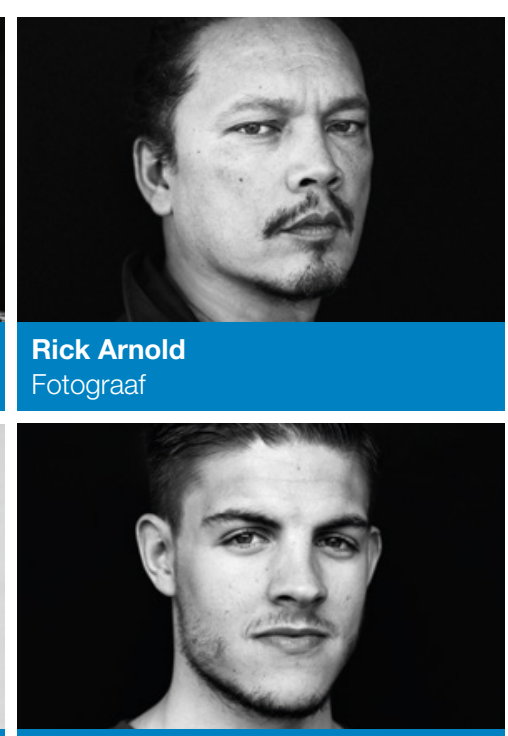

Luc Büthker

Fotograaf

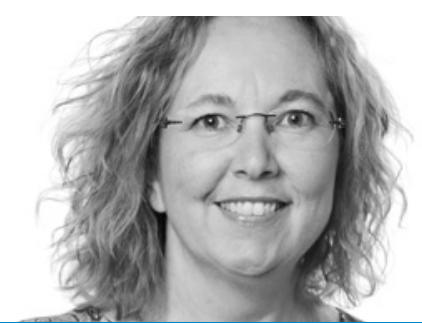

Corine Havinga Eindredacteur

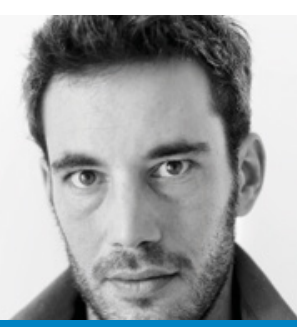

Eran Oppenheimer

Fotograaf
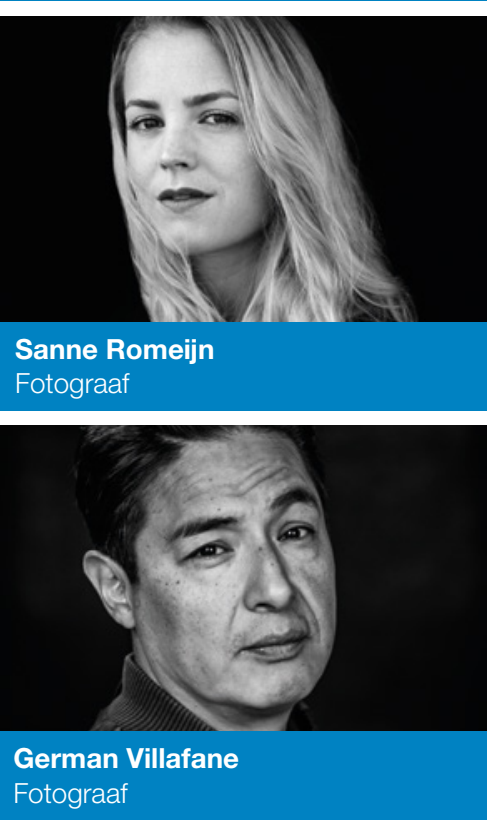

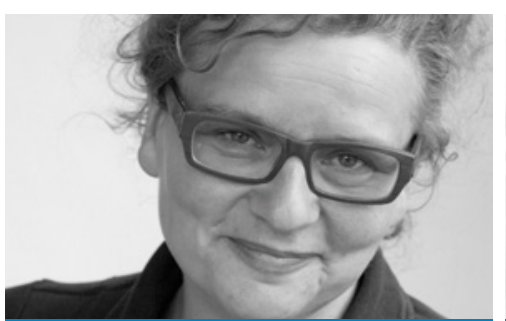

Christina Boomsma

Redacteur

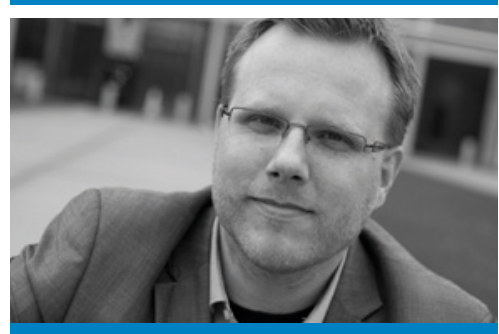

Remco Faasen

Redacteur
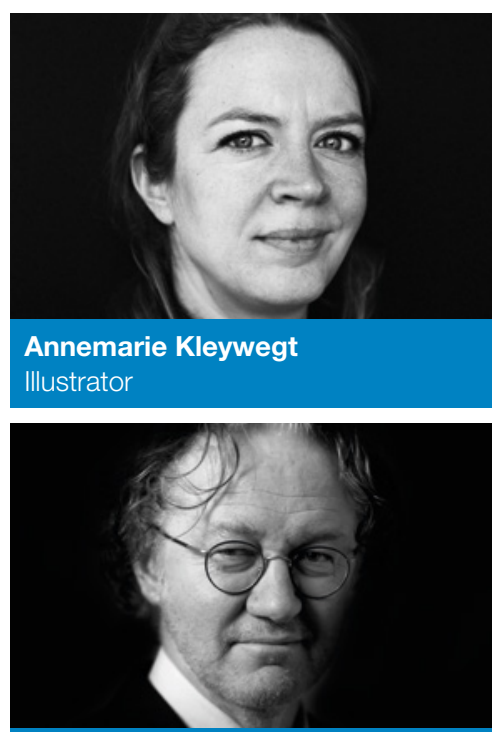

Bert Pol

Redacteur

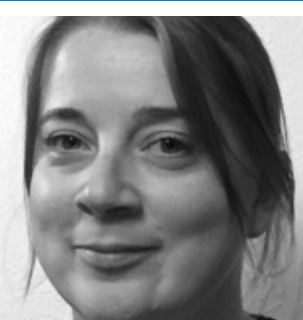

Marjolein Rozendaal

Redacteur

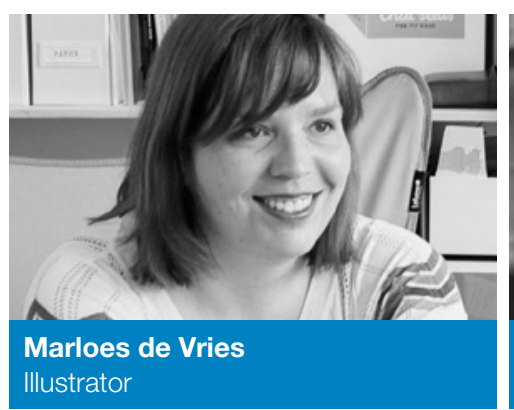

Arjen Boukema

Redacteur
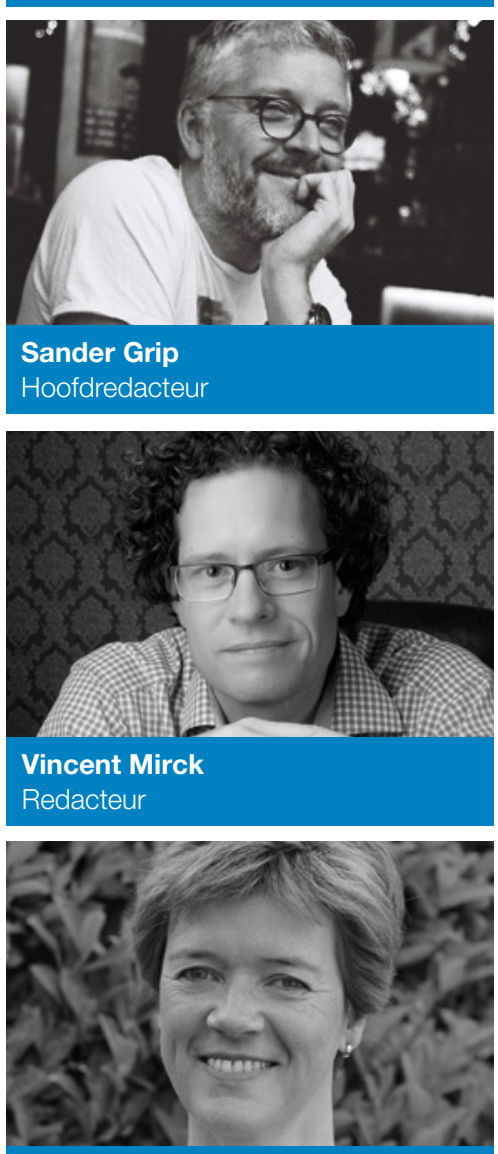

Els van der Pool

Gastredacteur

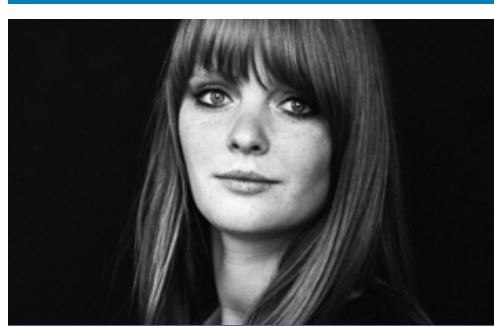

Jenny Spierenburg-Zaagman Ontwerper

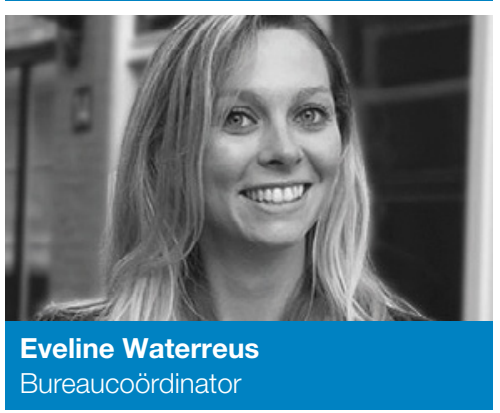

